\title{
Intrauterine malnutrition : neonatal and early childhood morbidity
}

Citation for published version (APA):

Walther, F. J. (1982). Intrauterine malnutrition : neonatal and early childhood morbidity. [Doctoral Thesis, Maastricht University]. Rijksuniversiteit Limburg. https://doi.org/10.26481/dis.19821022fw

Document status and date:

Published: 01/01/1982

DOI:

10.26481/dis.19821022fw

Document Version:

Publisher's PDF, also known as Version of record

\section{Please check the document version of this publication:}

- A submitted manuscript is the version of the article upon submission and before peer-review. There can be important differences between the submitted version and the official published version of record.

People interested in the research are advised to contact the author for the final version of the publication, or visit the DOI to the publisher's website.

- The final author version and the galley proof are versions of the publication after peer review.

- The final published version features the final layout of the paper including the volume, issue and page numbers.

Link to publication

\footnotetext{
General rights rights.

- You may freely distribute the URL identifying the publication in the public portal. please follow below link for the End User Agreement:

www.umlib.nl/taverne-license

Take down policy

If you believe that this document breaches copyright please contact us at:

repository@maastrichtuniversity.nl

providing details and we will investigate your claim.
}

Copyright and moral rights for the publications made accessible in the public portal are retained by the authors and/or other copyright owners and it is a condition of accessing publications that users recognise and abide by the legal requirements associated with these

- Users may download and print one copy of any publication from the public portal for the purpose of private study or research.

- You may not further distribute the material or use it for any profit-making activity or commercial gain

If the publication is distributed under the terms of Article $25 \mathrm{fa}$ of the Dutch Copyright Act, indicated by the "Taverne" license above, 


\section{INTRAUTERINE MALNUTRITION:}

\section{NEONATAL AND EARLY GHILDHOOD MORBIDITY}

PROEFSCHRIFT

Ter verkrijging van de graad van doctor in de geneeskunde aan de RIjksuniversiteit Limburg te Maastricht op gezag van de Rector Magnificus Prof. Dr. H.C. Hemker en volgens besluit van het College van Dekanen in het openbaar te verdedigen in de aula van de universiteit op 22 oktober 1982 des namiddags te vier uur,

door

F.J.WALTHER

geboren te's-Gravenhage 
Promotor: Prof. Dr. L.H.J. Ramaekers

Referenten: Dr. P.A. Davies

Prof. Dr. J. de Haan

Prof. Dr. C. Versluys 
Aan Marjolein 


\section{CONTENTS}

Abbreviations $\quad 6$

Preface 7

Chapter I General introduction

1.1 The smal1-for-gegtational age infant 9

1.2 Normal fetal growth 12

1.3 Eactors 1imiting fetal growth 15

1.4 Disproportionate intrauterine growth retardation as an expression of intrauterine malnutrition $\quad 20$

1.5 The aims of the studies, selection criteria

Chapter II Introduction to and discussion of the presented studies

2.1 Hydroxyproline, a biochemical parameter for the (prenatal) diagnosis of intrauterine malnutrition?

2.2 The ponderal index as an additional and refined measure to predict the neonatal morbidity of infants malnourished in utero

2.3 Postnatal growth of newborns affected by intrauterine malnutrition

2.4 Developmental aspects of intrauterine malnutrition

Sumnary

Samenvatting

References for chapter I and II

Publications presented in this thesis:

Intrauterine malnutrition and urinary hydroxyproline excretion 
Publication II

Publication III

Publication IV

Publication $V$

Publication VI

Publication VII

Acknowledgements

Curriculum vitae
The ponderal index as a measure of the nutritional status at birth and its relation to some aspects of neonatal morblaity

Neonatal morbidity of S.G.A. infants in relation to their nutritional status at birth 110 Growth in early childhood of newborns affected by disproportionate intraterine growth retardation

Skeletal maturity at birth and at the age of

3 years of infants malnourished in utero

Developmental aspects of subacute fetal

distress: Behaviour problems and neurological

dysinction

Language development at the age of 3 years of

infants malnourished in utero 150

164 


\section{ABBREVIATIONS}
A.G.A.
appropriate-for-gestational age
$B * \mathbf{Q} * \mathbf{R}$.
behaviour observation report
B.S.Q.
behaviour screening questionnaire
D.F.
degrees of freedom
I.U.G.R.
intrauterine growth retardation
I.U.M.
intraterine malnutrition
L
length
L. G. A.
large-for-gestational age
N.A.
not avallable
N.M.
neonatal mortality
N. S.
not ignificant
P
p-value
P.I.
ponderal index
P.N.M.
perinatal mortality
R.D.L.S.
Reynel1 Developmental Language Scales
S.D.
standard deviation
S.G.A.
mall-for-gestational age
T.H.P.
total hydroxyproline
T.H.P./Cr. ratio
total hydroxyproline/creatinine ratio
W
weight 


\section{PREFACE}

Intrauterine growth retardation is a major clinical entity in perinatal medicine. The magnitude of the problems of the smallfor-gestational age (S.G.A.) Infant is second only to prematurity as a cause of perinatal mortality and morbidity. The many unsolved questions surrounding this high risk group led to the publication of 3 dissertations in the Netherlands in the last 10 years. The first two studied the pathogenesis of neonatal hypoglycemia after intrauterine growth retardation: de Leeuw (1972) in small-for-gestational age newborn infants and Kollée (1980) in intrauterine growth-retarded rats. Lateber (1981) studied intrauterine growth retardation in the guinea pig and investigated some of the consequences of this condition.

The 7 studies in this dissertation cover 3 main subjects: (1) the research for a biochemical parameter for prenatal diagnosis of intrauterine malnutrition in humans, (2) the use of a welghtlength ratio (the ponderal index) as a measure to predict the neonatal morbidity of infants malnourished in utero, and (3) the growth and development in early childhood of infants affected by intrauterine malnutrition. These studies were performed in term S.G.A. Infants who were underwelght-for-length at birth. Thit. subgroup of S.G.A. Infants is ualualy known under the names "intraterine malnutrition'. "disproportionate intraterine growth retardation', and 'subacute fetal alstress' (and in the Netherlands as 'dysmaturity'). 



\section{CHAPTER I: GENERAL INTRODUCTION}

\subsection{The small-for-gestational age infant}

Low birthwelght newborns do not constitute a homogeneous group since low birthweight may be the result of premature delivery, of intrauterine growth retardation, or of both these factors in combination (warkany et al., 1961). Therefore these newborns must be classified in terms of both birthweight and gestational age. Those newborns born before the $37 \mathrm{th}$ week of gestation are called preterm infants whereas those having a relatively low birthweight for gestational age are called small-for-gestational age infanta.

To be able to classify newborns by birthwelght and gestational age reliable assessment of these parameters are critical. If the gestational age is not available (in case the mother is not sure of the date of her last menstrual period and/or her menstrual periods are irregular or she recently stopped the use of an oral. contraceptive) the obstetrician can use physical examination early in gestation in combination with pregnancy tests and serial measurements of the biparletal diameter of the fetal skull by ultrasound (Campbe11, 1969 and 1974; Queenan et al., 1976) to determine gestational age. The paediatrician can atimate the length of gestation to within plus or minus two weeks from the external physical characteristics (Farr et a1., 1966; Usher et al. 1966) or from the neurological development (Saint-Anne Dargassies, 1962; Amiel-Tison, 1968) of the infants, or from a combination of the two (Dubowitz et al* 1970).

Lubchenco et a1." (1963), compiled the first standards of intrauterine growth of (Caucasian) infanta providing a valuable graphic method to classify low birthweight infants in terms of both birthweight and gestational age. This led to a classification of newborns in 9 categories (Table 1-1). 
Table 1-1 Classiflcation of newborns based on birthweight and gestational age

\begin{tabular}{|c|c|c|c|}
\hline \multirow[b]{2}{*}{ Birthwe lght } & \multicolumn{3}{|c|}{ gestational age } \\
\hline & $\begin{array}{l}437 \text { weeks } \\
\text { (1ess than } 259 \\
\text { completed days) }\end{array}$ & $\begin{array}{l}37-41^{6} / 7 \text { weks } \\
(259 \text { to } 293 \text { days })\end{array}$ & $\begin{array}{l}\text { (22 weeks } \\
\text { (294 days or more) }\end{array}$ \\
\hline $\begin{array}{l}\text { L } 10 \text { h } \\
\text { percentile }\end{array}$ & preterm S.G.A." & term $\mathbf{S} \cdot \mathbf{G} \cdot \mathbf{A}$. & post-term S.G.A. \\
\hline $\begin{array}{l}10-90 t h \\
\text { percentile }\end{array}$ & preterm A.G.A.** & term A.G.A. & post-term A.G.A. \\
\hline $\begin{array}{l}\text { voth } \\
\text { percentile }\end{array}$ & preterm L.G.A.** & term $L . G . A$. & post-term L.G.A. \\
\hline
\end{tabular}

* S.G.A.: sma11-for-gestational age

* A.G.A. : appropriate-for-gestatlonal age

** L.G.A. * large-for-gestational age

Whereas there is international agreement on the definition of the preterm infant, no universally accepted definition of smallfor-gestational age (S.G.A.) is available. Using an intraterine growth curve arbitrary statistical limits are drawn to define S.G.A. Some authors (Lubchenco et al., 1963; Battaglia and Lubchenco, 1967; Babson et a1., 1970; Davies et a1., 1972) prefer to define S.G.A. a birthweight at or below the loth percentile for gestational age. Others (Gruenwald, 1963; Usher and McLean, 1969 advocate a birthweight more than 2 standard deviations below the mean for gestational age (corresponding to the third percentile on the intrauterine growth curve and a weight equivalent to 25 below the mean welght for gestational age). Still other authors (Thomson et a1., 1968; Davies et a1., 1979) prefer to use the 5 th percentile as cut-off point. Of additional concern is that not all infants affected by intrauterine growth retardation will be included in a definition based on a relatively low 
birthweight for gestational age: 1 fants may manifest wasting at birth even though their weights do not fall below the normal for gestational age (Usher, 1970) and infants may be relatively underweight for gestational age when compared with their siblings (Turner, 1971).

Since the data of Lubchenco et al. (1963, 1966) of infants born at high altitude (Denver, Colorado) numerous tables and graphs of birthweight in relation to gestational age have become available from smaller and larger populations in Western countries. Well known examples are those of Gruenwald (1966) in Baltimore (U.S.A.), of Usher and McLean (1969) in Montreal (Canada), of Thomson et al. (1968) in Britain, of Babson et al. (1970) in Portland (U.S.A.), and of Kloosterman (1970) in Amsterdam (The Netherlands). An important problem in obtaining normative fetal growth data is that they are derived from cross-gectional measurements made on infantis born in the latter half of pregnancy (with the exclusion of abnormal infants and multiple births). When delivery occurs before or after term, there may have been a physiologic handicap which may have adversely affected intrauterine growth. While these limitations must be borne in mind when interpreting intrauterine growth curves, there is no better method at the present time of deriving intrauterine curves of weight, length and head circumference in view of the inaccesibility of the fetus for study.

In the Netherlands recently a combination of the Usher-McLean (head circumference and length) and the Kloosterman intrauterine weight growth curves was chosen by the Dutch Neonatal society as a reference for intrauterine growth (Versluys, 1980) to eradicate the confusion due to the use of a large number of different intrauterine growth curves in Dutch hospitals. In adaition moderately S.G.A. was defined as a birthweight below the loth percentile for gestational age and severely s.G.A. as a birthweight 


\subsection{Normal fetal growth}

Two basic factors govern the velocity of fetal growth: the intrinsic growth potential of the fetus, which is genetically determined (Polani, 1974), and the growth support it receives via the mother and the placenta (Gruenwald, 1966). Animal data have shown that normal intrauterine weight growth of the fetus describes a sigmoid curve from conception till birth at term (Widdowson, 1970). Human fetal weight growth is almost linear from 28 to about 37-38 weeks, after which there is a gradual reduction in growth rate at term, with only minimal growth after term. This is

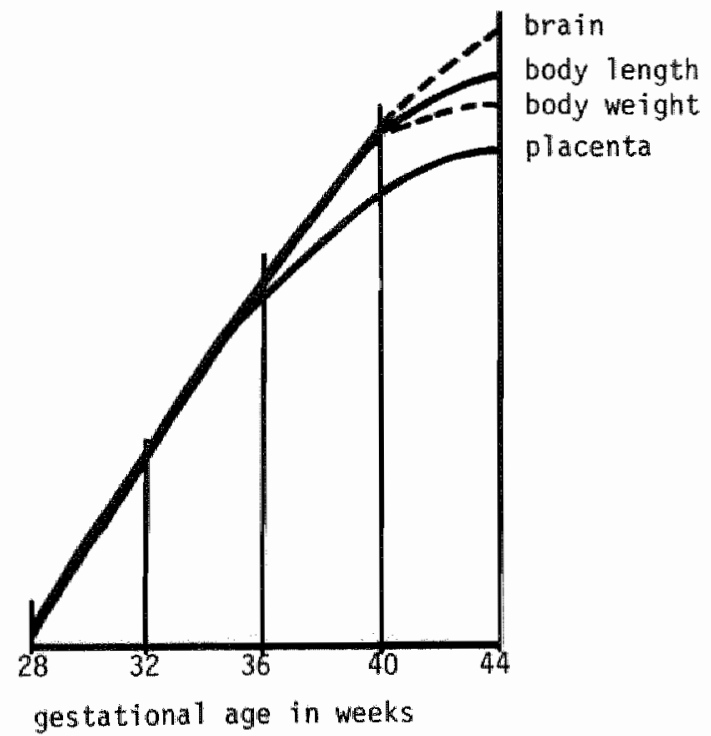

Fig. 1-2 Growth of brain, length, weight, and placenta postterm, adapted from Gruenwald (1974)

also true for other dimensions like length and head circumference (Usher and McLean, 1969). In post-term infants growth deceleration especially affects body weight, body length is less affected, whereas head size is least affected (Gruenwald, 1964 a) (fig. 1-2). The ponderal index, a weight-length ratio (100 $\mathrm{x}$ $w / L^{3}$ ) used to calculate the relative amount of soft tissue mass 
present in an infant, shows a gradual increase from 30 through 37 weeks as the fetus accumulates (amongst others) subcutaneous fat (Widdowson, 1974 a). At term the ponderal index remains stable and is not affected by race, sex and parity. Post-term the ponderal index decreases as the increase in length is less reduced than the increase in weight at that time (Miller and Hassanein, 1971).

Probably some 40 of birthweight variation can be attributed to genetic variables whereas about $60 \%$ of the variation results from the enviromment in which the fetus grows, of which a greater part is dictated by maternal health and nutrition (Polan1, 1974). Gruenwald (1966) suggested that if maternal growth support was unlimited, the growth rate of the fetus would proceed in a linear fashion towards term and post-term. There are two limiting factors which may influence late fetal growth to a large extent: (1)

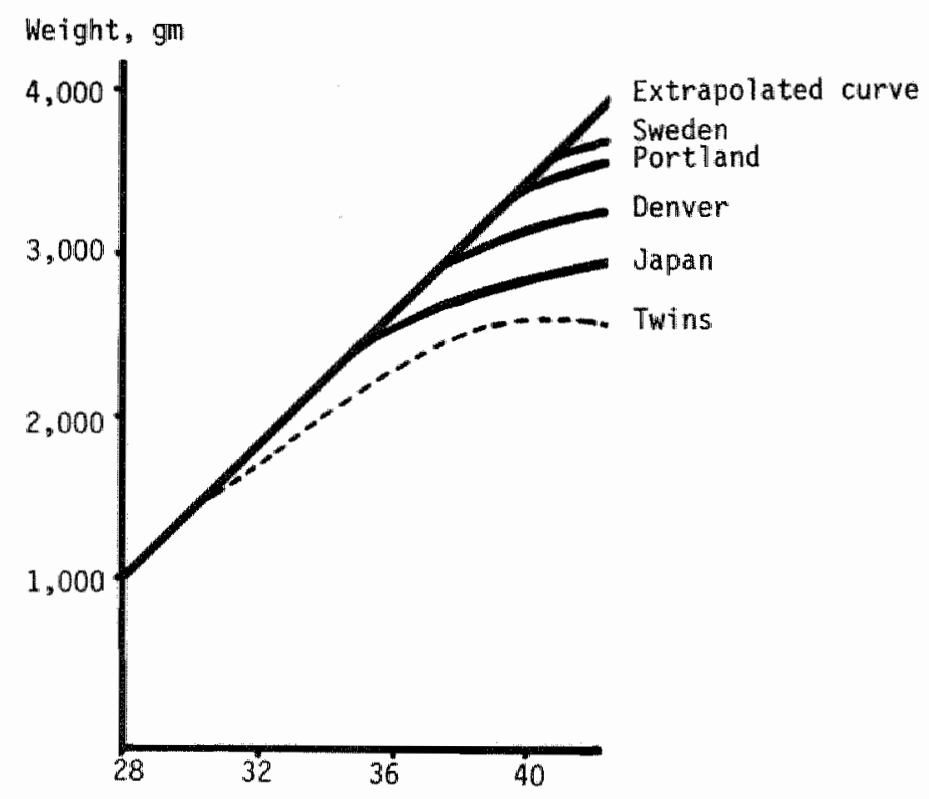

Fig. 1-3 Smoothed birth weight curved, auggesting that in each population departure from the straight line occurs when the supply line becomes insufficlent to support the growth potential. Adapted from Gruenwald (1974). 
the diminution of supplies from the mother to the fetoplacental unit because of a suboptimal utero-placental circulation, and (2) uterine constraints. Thls view is supported by the fact that the Imediate postnatal growth of the fetus quickly accelerates to the pre-38 weeks growth rate once it has been released from the (normal) constraints of the uterine environment. From this evidence it would seem that ultimately birthweight is determined by the lope of the growth potential line, the gestational age, and the limiting factora occurring under normal circumstances (Ounsted and Ounsted, 1973, Dunn, 1981). The dize that the human fetus could attain if the factor of maternal constraint was removed is a matter for speculation.

Gruenwald (1966 and 1974) demonstrated that all Western populations atudied have similar, straight-line birthweight curves early in the third trimester, and depart from this straight line when the adequacy of the supply line to the fetus aiminishes. This happens in each population at a time determined by the different limiting factors which are present le.g. maternal nutritional status, race, and living at high altitude) (fig. 1-3). The lowest curve in figure $1-3$ presents the growth of twins as an example of a group with a supply line which is limited more than 1t is in singletons. This figure also provides the intrauterlne growth curves of Sweden, Portland, Denver, and Japan. In Sweden, the population with the largest babies, the deviation from the growth potential line occurs later in pregnancy than in a country with a shorter population like Japan. The Denver data (altitude $1,609 \mathrm{m.}$ ) describe an average U.S.A. population living at high altitude, the Portland curve was based on Caucasian infants living at sea level who were cared for by private physicians.

Growth at a cellular level has been investigated in animal studies (e.g. Winick and Noble, 1966; Hi11, 1974, Widdowson, 1974 
b). Three phases of development were proposed: first, a period when growth is entirely due to cell hyperplasia; second, a phase when growth is both by hyperplasia and hypertrophy and lastly" a phase when growth is entirely by hypertrophy. Dobbing and Sanas (1973) studied human abortuses, stillbirths, and neonatal deaths and described two phases of accelerated brain growth: one from 15 to 20 weeks of gestation, which is due to neuroblast proliferation, and the second from 25 weeks onwards which is the result of glial proliferation. Thus neuronal hyperplasia occurs during a phase of fetal growth without obvious limiting fetal growth factors. In addition to glial proliferation, many important changes are occurring in the late fetal brain such as myelination, denaritic arborisation and synapse formation whilch have profound influence on intellectual development. Though in man relatively little information is available, Dobbing and Sanda (1970) found that cell hyperplasia ceased in the human brain during the second postnatal year.

Recently Dobbing and Sands challenged the entire 'cell number/ cell size" hypothesis by the demonstration that the three postulated phases of development do not occur in the human brain (Dobbing and Sands, 1981), nor in the 'non-neural' tissues like liver, kidney, heart, and gastrocnemius muscle (Sands et all., 1979). In all these tissues cell growth in size is apparently an early first event, coming to an end long before the process of cell division, which in turn continues as long as the growth of the tissue itself. This is exactly the opposite of the aequence originally proposed but it does account more satisfactorily for the fallure of developing brain, as well as other tisaues, to catch up following early nutritional or other growth restriction.

\subsection{Factors limiting fetal growth}

Reduced fetal growth rate can result from (1) a reduction of the 
normal growth potential of the fetus and (2) from inadequate maternal apport for fetal growth. Reauced growth potential can result from chromosomal abnormalities and genetic variabilities (Reisman, 1970; Polan1, 1974), from congenital anomalies (Van den Berg and Yerushalmy, 1966). from intrauterine infections (Hughes, 1970), or from teratogenle agents.

Although chromosomal abnormalities are estimated to occur in about 6\% of all conceptions (Wright, 1976) their numerical contribution to I.U.G.R. is limited (Kelrse, 1981). The large majority of such pregnancles is lost before viability is reached and of the remainder about one thild is accounted for by translocations which lead only rarely to a substantial alteration of growth. Most chromosomal abnormalities resulting in live birth, lead to a reduction of birthweight. Trisomy 21 (Down"s syndrome), trisomy 18 (Edwards" syndrome), trisomy 13 (Patau's syndrome), Turner'syndrome $(45, \mathrm{xO})$, and Klinefelter"s syndrome $(47, \mathrm{XXY})$ are well known examples (Polani, 1974). The effect of autosomal abnormalities is even more marked than that of anomalies of the sex chromosomes (Polani, 1974). The influence on weight of chromosomal abnormalities seems to be mediated through cellular changes and to be in essence the result of a prolongation or a ahortening of apecific phases of the cell cycle." The apecificity and the direction of the effect depend on the nature of the chromoøomal anomaly.

Intrauterine infectiong of viral origin will affect both fetus and placenta, but their negative effects on fetal growth depend on the timing of the intrauterine infection and will possibly to some extent be medilated by the effects of maternal iliness (Coid, 1973). About 45 of infants with congenital rubella have a birthweight below the 5 th percentile for gestational age (Turner, 1971), whereas 80 s have an abnormally low birthweight when compared with the birthwelght of their normal siblings (Turner, 
1971). In I.U.G.R. due to rubella infection the liver and the spleen are rather large for bodywelght (because they are diseased) whereas the brain appears to be less protected than $\mathbb{1}$. many other causes of growth retardation (Naeye and Blanc, 1965). The rubella infection leads to a diminished cell multiplication, resulting in a numerical deficit of cells (Naeye and Blanc, 1965; Hughes, 1970).

Cytomegalovirus infection during pregnancy only leads in a minority of cases to I.U.G.R. (Hanshaw et aI., 1973): if the infection is acquired around birth, weight may be normal, but if it is acquired much earlier the newborn is more likely to show growth retardation (Waterson, 1979). Congenital toxoplasmosis and syphilis may induce growth retardation, but their incidence is rather low and they do not invariably result in I.U.G.R. Though it is known that listeria infections may cause meningoencephalitis, and chorloamnionitis with preterm delivery and neonatal pneumonia, little is known about the influence of bacterial infections on the fetus.

High dosage ionizing radiation (Brent and Jensh, 1967), cytostatic drugs (Scott, 1977) and the administration of corticom steroids during pregnancy (Howard and Hill, 1979) may result in severe growth retardation. However in practice it is often very difficult to differentiate between the effects of the mentioned therapies and the effects of the maternal disease.

Excluding the indicated causes of I.U.G.R., the factors that may influence the adequacy of the supply line to the fetus (Gruenwald, 1964 b) can be roughly divided into 2 main groups: (1) placental factors, and (2) maternal factors.

It has always been tempting to attribute the birth of an unduly small infant to a functional inadequacy or inaufficiency of the placenta. A critical survey of the posalble causes of intrinsic placental inadequacy indicated that very few of these 
cun produce a degree of functional insufficiency sufficient to account for a low birthwelght infant (Fox, 1976; Fox, 1981). There are Eour basic pathological mechanisms which can be held responsible: a) faulty placentation (esp. placenta circumvallatal, b) a reduced mass of functioning villous tissue lesp. extensive infarction), o) abnormal villous development (esp. villous immaturity), and d) diffuse villous damage due to infection (malar1a). aging, reduced fetal perfusion (haemangiomata of the placenta) and utero-placental ischaemia.

As intrinsic placental malformation il a rare cause of underweight at birth, a more important factor leading to a failure of fetal. growth is an inadequate supply of nutrients by the mother to the fetoplacental unit because of compromised utero-placental. exchange (Fox, 1981; O'Shaughnessy, 1981).

A great many maternal factors or conditions have been shown to be associated with I.U.G.R., for instance maternal nutrition (Naeye et a1., 1973; Stein and Susser, 1976), smoking (Naeye, 1979: Nurphy et al., 1980; Haworth et al., 1980 a and b; Bosley et al., 1981), alcoholl and drug use (Redmond, 1979: De Lange, 1979). inadequate prenatal care (Miller and Hassanein, 1973), and Low socio-economic class (Drillien, 1970). There appears to be a congensus of opinjon that maternal vascular pathology, whether it is aue to renal alsease, essential hypertension, collagen-vascular disease or diabetes, is the single most common denominator in the causation of I.U.G.R. (Reirse, 1981). Dawes (1974) estimated maternal vascular disease to be responsible for approximately 358 of S.G.A. newborns.

Table 1-4 provides a picture of the many causes of retarded fetal growth. In the meantime it is still not really clear to what extent these conditions are responsible for I.U.G.R. General practice learns that a great number of specific fetal diseases (Usher, 1970), maternal factors (M111er and Hassanein, 1973: 
Keirse, 1981) and placental lesions (Fox, 1976, 1981) are responsible for only a minority of the problem of reduced fetal growth. In the vast majority of S.G.A. infants no obvious cause can be identified which may explain their retarded growth (Dubowty. 1974; Usher and McLean, 1974; Renfield, 1975).

Table 1-4 Causes of intrauterine growth retardation ladapted from Behrman, 1979; Fox, 1981, and Lafeber, 1981)

A. Fetal and feto-placental factors

- chromosomal disorders (e.g." autosomal trisomies)

- chronic fetal infection (e.g., rubella, cytonegallic inclusion disease)

- congenital anomalies (e.g., congenital heart disease)

- teratogenic agents (e.g., drugs, radiation injury)

- multiple gestation

- genetically determined variations

B. Maternal factors

- vascular disorders (e.g., toxaemia, eclampsia of pregnancy, hypertensive cardiovascular disease)

- hypoxia (e.g." high altitude, sickle cell anaemia)

- maternal addiction (e.g., heroin, alcohol, smoking)

- extreme malnutrition

- socio-economic factors

- small stature

- uterine constraint

C. Placental and materno placental factors

- Ealty placentation (e.g., placenta circumvallata)

- reduced mass of placental tissue (e.g.. extensive infarction)

- abnormal villous development (e.g., villous immaturity)

- diffuse damage to the placental vilil (e.g. Infection) 


\subsection{Disproportionate intrauterine growth retardation as an expression of intrauterine malnutrition}

Many descriptive names have been and are used to designate the growth retarded newborn: intrauterine growth retardation (warkany et al., 1961; Lugo and Cassady, 1971), smal1-for-dates (Butler and Bonham, 1963), intrauterine malnutrition (scott and Usher, 1966), Ilght-for-dates (Daviez et a 1. 1979), prenatal dystrophia (Thalhammer, 1964), pseudapremature infants (Söderling, 1953), chronic and subacute fetal distress (Gruenwald, 1963), fetal malnutrition (Miller and Hassanein, 1973), fetal dystrophy (K100s and vogel, 1974), dysmaturity (sjöstedt et al., 1958; de Leeuw, 1973), and smal1-for-gestational age (Lubchenco et al., 1966). Among these the terms mall-for-gestational age (S.G.A.) and small-for-dates are most commonly used at present.

The majority of intrauterine deprived infants are borm at or near term (Usher and McLean, 1974; Neligan et a1., 1976; Ounsted et a1., 1981). In the Groningen Perinatal Project $7.5 \%$ of the S.G.A. Infants (birthweight $<10$ th percentile) were born preterm (Jurgens-van der zee et al., 1979). Ounsted et al. (1981) reported a percentage of 6.78 in S.G.A. infants (birthweight $<2$ s.a. below the mean). If the nutrient supply to the fetus becomes insufficient to maintain normall fetal growth by the third trimester (there are few limiting factorg prior to the 24 to 26 th week of gestation other than those which the genetic program dictates: Warshaw, 1974), two main clinical patterns of intrauterine growth retardation may emerge, depending upon the duration, intensity and time of onset of the growth retardation (Gruenwald, 1963 and 1974): (1) Chronic fetal distress has a duration of months, often beginning early in the third trimester. At that time muscle mass is small and no sizable panniculus adiposus has yet developed. Thus, no 'wasting' can occur and external body proportions (weight, length, and head circumfer- 
ence) are very similar to those of normally grown, preterm infants. These infants can be characterized by standard criteria of wellght deficit, but not by such measures of body proportion as the ponderal index because they present proportionate intrauterine growth retardation. The maturation of these infants is very little affected and is advanced out of proportion to body weight as it remains related to gestational age. (2) subacute
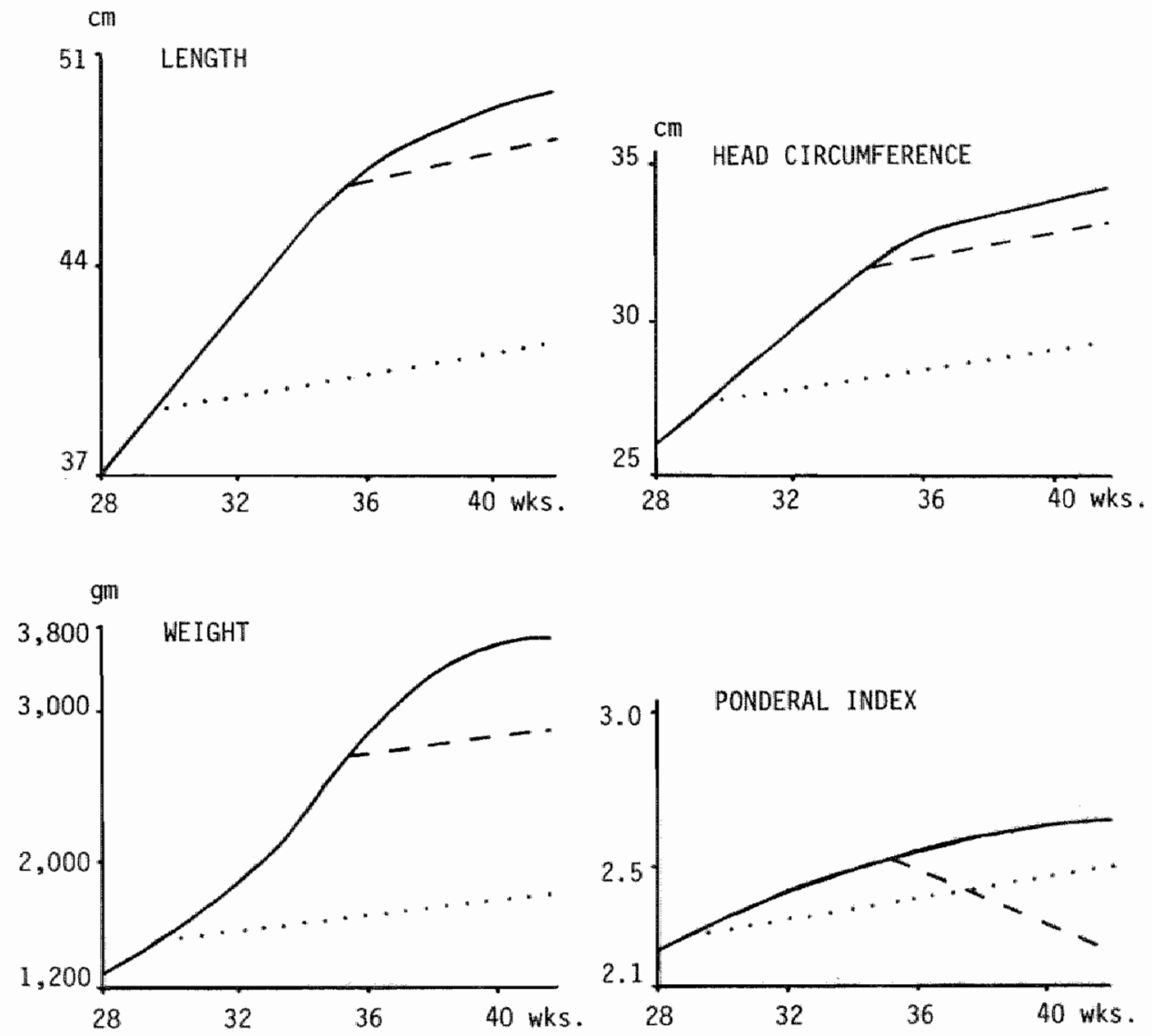

Fig. 1-5 50th percentiles of normal intrauterine growth in welght, lenght, head circumference and ponderal index (wellght-length ratio), adapted from Lubchenco et al.. 1966. The 2 main patterns of intrauterine growth retardation (aisproportionate I.U.G.R. = - - - and proportionate I.U.G.R. = .....) are inserted. 
fetal distress, lasting for days or several weeks, usually affects fetuses near or past term who have grow to approximately Eull size for length and head circumference, but failed to develop a paniculus adiposus. This leads typically to a disproportion of (neax) normal head circumference and body length and subnormal welght, with a reduced quantity of subcutaneous adipose tissue: disproportionate intrauterine growth retardation (fig. 1-5). The reduction in birthweight may not be sufficiently great to be detected waing birthweight for gestational age as criterion. This clinical classiflcation is (although useful) by no means infal11ble: there is a gradual overlap in the clinical characteristics of these two types of intraterine growth retardation. But this classification is an attempt to determine the degree of I.U.G.R. so that subsequent studies will be able to define exactly the type of infant under discussion.

The ponderal index, (100 $\mathrm{x}$ weight/length ${ }^{3}$ ), a weight-length ratio, was introduced by Rohrer (1921) for assessment of the nutritional satus and for comparisons among groups of infants. This index has also been used to judge the nutritional status of newborns (Lubchenco et al., 1966; Miller and Hassanein, 1971; Gruenwald, 1974; Roord and Ramaekers, 1978). Between 30 and 40 weok of gestational age, the 50 th percentile of the ponderal index increases from 2.33 to 2.62 (Lubchenco et al., 1966). showing that the fetus becomes heavier for his length during the last trimester of pregnancy due to the accumulation amongst others of subcutaneous fat and muscle (Widdowson, 1974 a). In chronic fetal distress (proportionate I.U.G.R.) the index is low for gastationall age, but is only slightly below the average when compared with that of infants whose weight is similar but appropriate for their gestational age. In subacute fetal distress (disproportionate I.U.G.R.) the index is considerably below normal no matter how it is considered (Gruenwald, 1974), see fig. 
1-6. Especially at term the ponderal index provides valuable information about the nutritional status of the newborn: preterm infants have little subcutaneous fat and those with I.U.G.R. Will have to be diagnosed by weight deficit. In clinical practice disproportionate I.U.G.R. is (depending on its severity) easily recognizable by the outward appearance of the newborn (warshaw, 1979). The skin is ample and wrinkled with practically no subcutaneous fat. Widened skull sutures are present secondary to failure of bone growth, the head is relatively large. These newborns are usually alert, active, and seem hungry, although not necessarily from the first minutes of life. Meconium staining of the skin, nails, and umbilical cord is especially common in post-term infants.

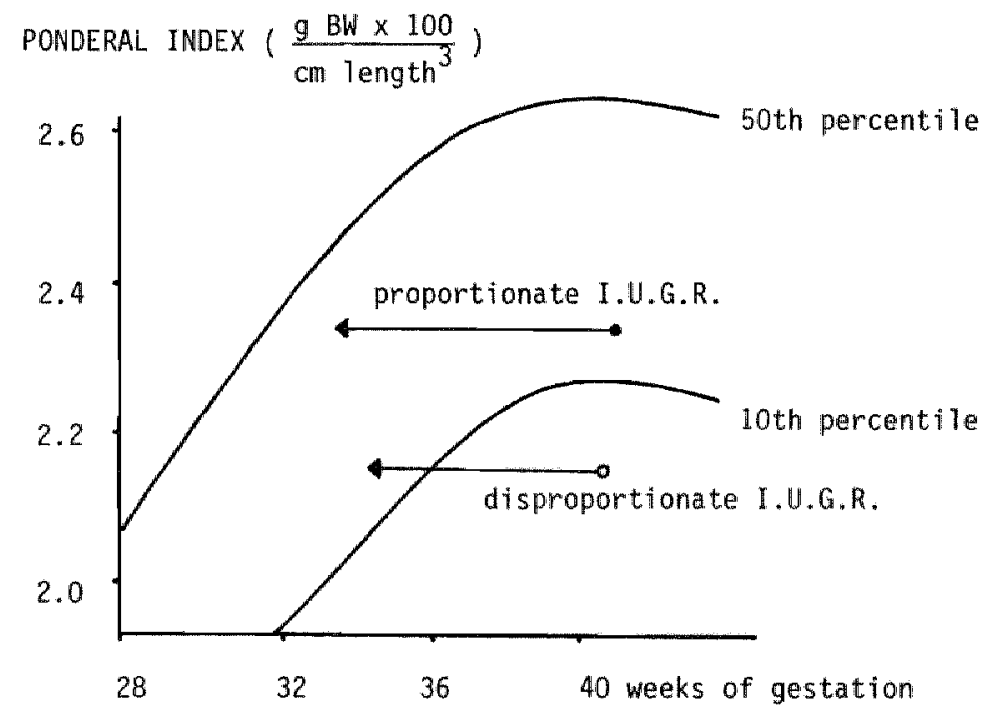

Fig. 1-6 Ponderal index of a representative case of disproportionate I.U.G.R. and proportionate I.U.G.R. The hor:zontal lines connect these with the points on which they would fall if their gestational age was commensurate with their actual birthweight (derived from Gruenwald, 1974). 
Those term (s.G.A.) infants with clinically characteristic igns of intrauterine malnutrition and a relatively low ponderal Index t to indleate underwelght-for-length c.q. suboptimal nutritionall status) constitute the study groups in this thesis. Several ynonyma have been used to describe them (intrauterine malnutrition, subacute fetal distress, and disproportionate intrauterine growth retardation), but aisproportionate intraterine growth retardation wa chosen in preference to any other synonym as the nutritional status was estimated in the ensuing studies by measuring and comparing welght and body length at birth.

\subsection{The aims of the studies and selection criteria}

Many of the early follow-up studies discussing the consequences of intrauterine deprivation are invalidated by the lack of adequate assessment of gestational age at birth and by the lack to define precisely the selection of the small-for-gestational age infants. One of the best-controlled studies has been that of Fitzhardinge and steven (1972 a and b) who did a follow-up study of 96 term S.G.A. (birthweight more than 2 standard deviations below the mean) singleton infants born in Montreal in the years 1960-1966 who had no obvious cause for the growth retardation in the way of congenital malformations, infection, chromosomal abnormalitles, and so on. This and other studies were performed before the introduction of modern intensive prenatal and postnatal care which eliminateg many major risk factors for perinatal morblaity (for example early screening of blood glucose in combination with early and appropriate feeding lowered the incidence of neonatal hypoglycemia sharply). Furthemore these studies did not attempt to define the severity of the intraterine growth retardation (chronic or subacute). So the question arose to what extent is past information still relevant when the "black box" is opened at birth (when one is able to see the infant, to weigh it, 
to measure it and to classify itl and the infant is subjected to the advanced perinatal care of the late seventies.

\section{Aim I:}

In the light of the above mentioned imperfections we became interested in the effect of intrauterine growth retardation on the long term morbidity of intrauterine malnourished infants who did fully benefit from modern perinatal care. To exclude morbiaity due to the special problems of the preterm infant our absequent studies were directed towards infants born at term. To define small-for-gestational age the loth percentile of the Dutch weight-for-gestational age curves lallowing for sex and birth order) of Kloosterman (1970) was used. To avoid racial growth differences and the adverse effects of multiple pregnancy only Caucasian singletons were selected for further study. Infants with an obvious fetal disease (congenital malformations, infections, chromosomal anomalies) leading to growth retardation in utero and infants who were genetically small were excluded from the studies". To eliminate the adverse effects of additional perinatal problems "1ike artificial delivery, asphyxia, acidosis, hypoglycemia, hyperviscosity, hyperbilirubinemia, hypothermia, and respiratory difficulties) on long term morbidity, only infants who were free from the mentioned factors were investigated. Ultimately the loth percentile for gestational age of the ponderal index was used to select especially those term caucarian singleton S.G.A. infants whout fetal diseases who were underweight-for-length at birth for in other words demonstrated aub-

\footnotetext{
*The genetically small infant were identified by adjustment of their birthweight for maternal size according to Thomson et al., 1968; furthermore the ponderal index of these infants is (near) normal as both weight and length are amall for geatational age.
} 
acute fetal diatres m disproportionate intraterine growth retardation). Using these criteria several studies were performed with the ultimate dim to establish the early childhood morbidity of disproportionally grown term S.G.A. infants without fetal and neonatal diseases. Physical growth and developmental aspects were considered In a prospective study of 25 infants born in 19751976. These investigation were also performed in appropriate controlls (term A.G.A. Infante who were free from perinatal morbidity) carefully matched for age, sex, birth rank, and social class. At the age of three years (1979) growth was assessed by evaluating weight, length, head circumference, skinfold, and skeletal maturity. The results of this study have been described In publications IV and $V$. Development was assessed by testing behaviour, neurological and language development, all parameters of higher cerebral functions. Publications VI and VII describe the results of the developmental aspects of disproportionate intrauterine growth retardation.

Aim II:

In $1978 / 1979$ we investigated the use of the excretion of hydroxyproline in the first urine as a biochemical index of the duration and aeverity of intrauterine malnutrition of term infants. This Inveatigation (publication I) was undertaken in the light of the conflicting results about this subject presented by different author in the last decade (see 2.1). The ponderal index was in this study used to quantify intrauterine malnutrition as the participating newborns ranged from normally grown infants to infante geverely malnourished in utero.

\section{Aim III:}

More recently (1979-1981) we studied the incidence of disproportionate intrauterine growth retardation at term and the incidence of several neonatal problems among disproportionally (subacute 
fetal distress) and proportionally (chronic fetal distress) grown term S.G.A. infants. In these papers (publications II and III) the ponderal index was again used as a measure of the nutritional status at birth. The aim of these studies was to test if disproportionally grown term S.G.A. Infants are more liable to neonatal complications than proportionally grown term S.G.A. infants, a feature regularly observed in daily clinical practice. Those complications which are easy to define and to quantify and which are clinically relevant (asphyxia, acidosis, hypothermia, hypoglycemia, hyperviscosity, hyperbilirubinemia), were therefore considered in relation to birthweight and to ponderal index. 


\section{CHAPTER II: INTRODUCTION TO AND DISCUSSION OF THE PRESENTED STUDIES}

2.1 Hydroxyproline, a biochemical parameter for the (prenatal) diagnosis of intrauterine malnutrition?

Although anthropometric values like weight, length, head circumference, and skinfold thickness are useful parameters to diagnose the severity of intrauterine malnutrition at birth, it remains difficult to assess the duration of the intrauterine growth retardation using these parameters. Several studies (Scott and Usher, 1964; Finnstrŏm, 1971; Pryse-Davies et a1., 1974, sénécal et a1., 1977; Roord et al., 1978) have demonstrated that the ossification of epiphyseal centres (skeletal maturity) is markedly delayed when the fetus is malnourished in utero. Roord and Ramaekers (1978) showed that the severity of intrauterine malnutrition can be quantifled by calculating the difference between the actual ponderal index $\left(100 \times \mathrm{W} / \mathrm{L}^{3}\right)$ and the ponderal index of 'normally' grown infants (arbitrarily $p 50$ values) and that this deviation from 'normal' correlated in a highly' silgnificant manner with skinfold measurements as a measure of the nutritional status at birth. Except that the ponderal index proved to be a valuable parameter of the nutritional status of the newborn, another study by Roord et al. (1978) established a close relation between skeletal. retardation and negative deviation of the ponderal index from normal.

Interested in the possibility of employing a biochemical test for detecting the nutritional status in utero, the described link between anthropometric values (especially the ponderal index) and skeletal maturity at birth contained a possibility for further studies. As a major part (more than 508) of the total body collagen stores is present in bone and as the rate of turnover of 
collagen in bone is high (Neuberger and slack, 1953), the metabalism of collagen might provide a parameter to quantify intrauterine growth retaration biochemically. The occurrence of hydroxyproline in collagen is of special interest since this amino-acid has been found only in collagen. Most of the hydroxyproline is present in collagens as the trans-4-isomer, but all known collagens also contain a small amount of trans-3-hydroxyproline, and basement membrane collagens are relatively rich in 3-hydroxyproline. Its unique place in collagen metabolism is based on the essential role of the hydroxylgroup of hydroxyproline in stabilizing the triple helix of collagen (Prockop et al". 1979). Although the bulk of body collagen is remarkably stable, a fraction of the collagen in all tissues is continually degraded and. replaced, even in old age. Such changes in overall collagen metabolism can be conveniently followed by assaying excretion of hyaroxyproline in urine (Kivirikko, 1973), as excretion of this substance is largely caused by collagen degradation and as collagen degradation parallels the decrease in collagen synthesis that occurs with age. Further studies on hydroxyproline have been facilitated by the fact that neither free hydroxyproline nor the hydroxyproline - containing polypeptides produced during the normal in-vivo degradation of collagen and excreted in the urine, are re-incorporated into collagen (stetten, 1949: Bensuan and Klein, 1965). By means of tracer experiments it has been demonstrated that only free proline is bulit into the polypeptide chain of the collagen precursor protocollagen, and that subsequently part of these proline residues are hydroxylated to hydroxyproline (vdenfriend, 1966: Prockop et a1., 1979). In normal children and in adults, about 95 of hydroxyproline (HP) is excreted in the peptide-bound form, and this fraction accounta for most of the increased hydroxyproline excretion rate occurring in various diseases affecting collagen metabolism, and 
condthons as sociated wh depressed. or increased rate of growth (Jagin et al. 1962 a, b: Smiley and zify, 1962, picon et al., 1965; Graf and vest, 1971; Wharton et $a 1 ., 1972$ and 1973 ; Cabacungan et al., 1973; Chandrachkharan and Cand1isch, 1973; Te1ler et al., 1973; Futrell et a1."1975; Laitinen, 1975; Edwate a $1 ., 1976$ ).

Figure 2-1 shows the total hydroxyproline/creatinine (THP/Cr) ratio in urines from children of different ages (according to

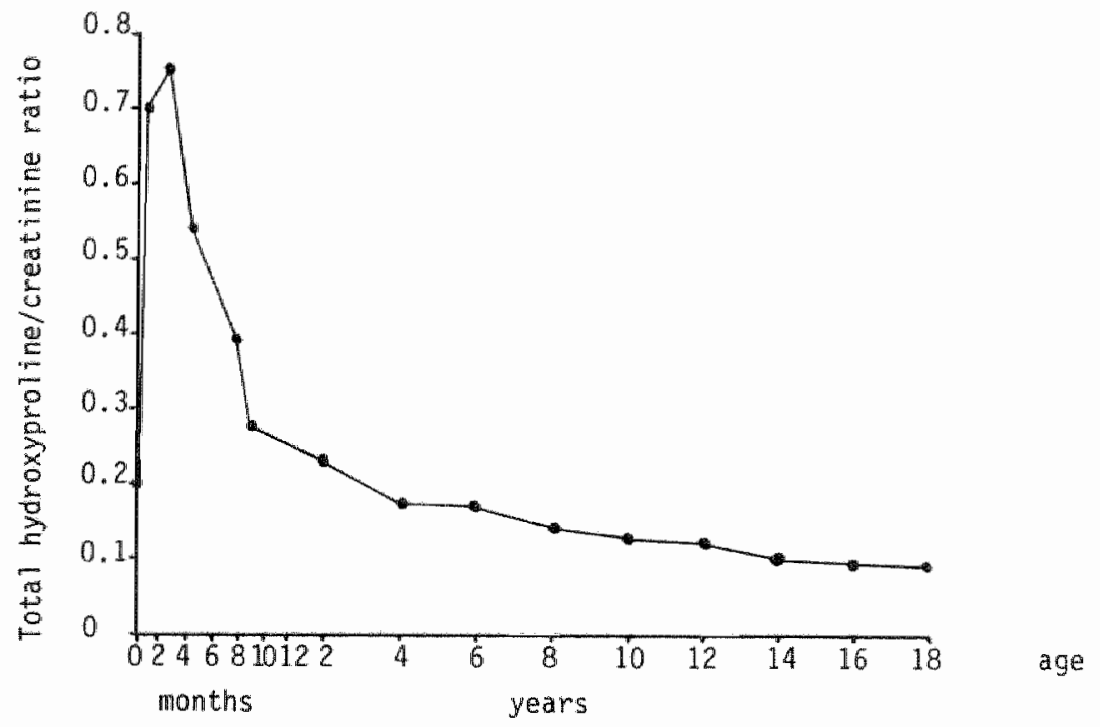

Fig. 2-1 Total hydroxyproline (mmol/1)/creatinine (mol/1) ratio in urine collected from normal children of 0 to 18 years of age (adapted from Graf and vest, 1971).

Graf and Vest, 1971), about equal figures were presented by Whatton et a1. (1972). Both studles demonstrate that after birth the ratio rises rapidiy lcreatinine excretion remains table and hydroxyproline excretion rises), reaching a peak towards the end of the neonatal period. Thereafter it falls progressively with increasing age, the reason is that creatinine excretion rises with increasing size and musculature whilst hydroxyproline excretion shows much less marked changes with increasing age. In fact 
during the first year of life the amount of hydroxyproline excreted per $\mathrm{kg}$ bodyweight is larger than after infancy. The increased rate of growth during puberty manifests itself in apld increase of the absolute value of the excreted hydroxyprollne from the age of 9 years onwards (fig. 2-2). This increase parallels the gain in weight and height (in girls earliex than in boys). At the same time creatinine and nitrogen excretion rise

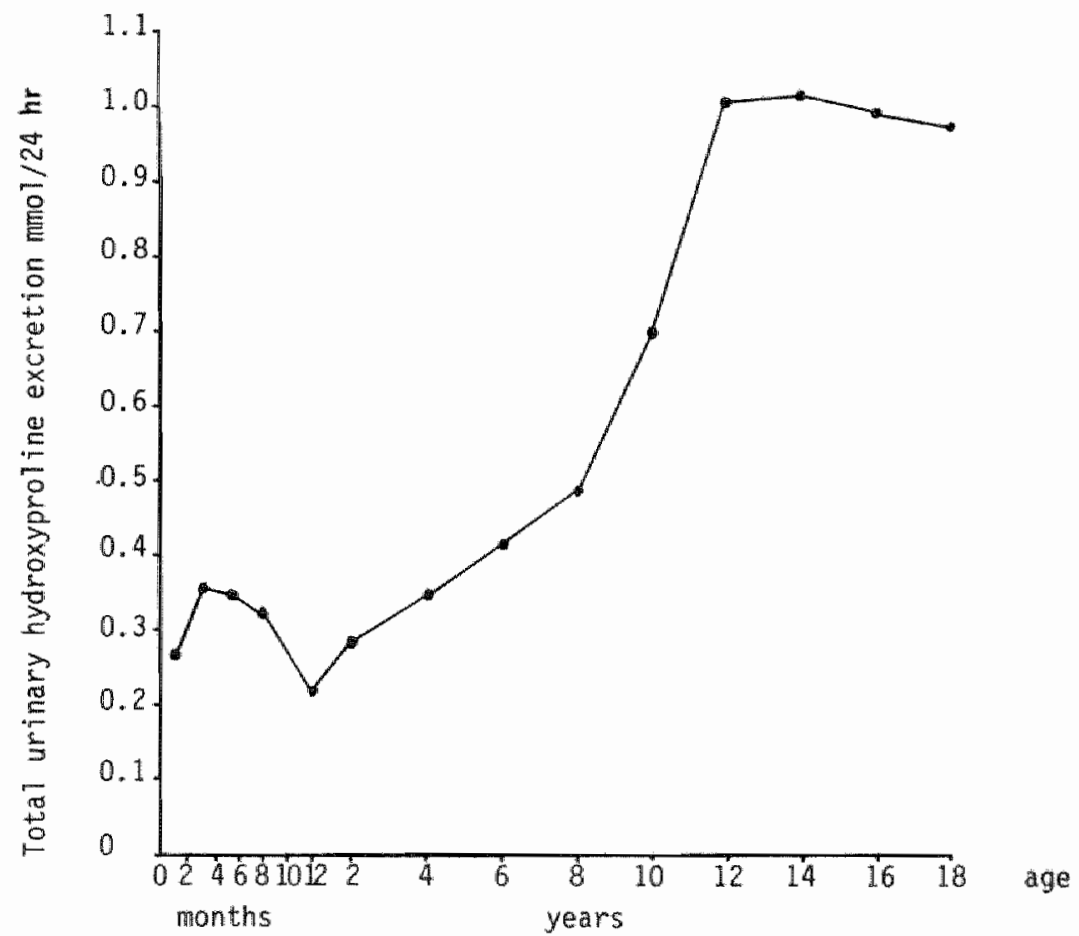

Fig. 2-2 Total hyaroxyproline excretion (minol/24 hr) in urine collected from normal children of 0 to 18 year of age (adapted from Graf and Vest, 1971).

and as a result the THP/Cr ratlo continues to fall auring puberty. Whereas a rapid growth rate results lexcept during puberty) in an increased $\mathrm{THP} / \mathrm{Cr}$ ratio, malnutrition leads to a decreased ratio (Picon, 1965; Whitehead, 1965 and 1969, Howells et a1., 1967; Chandraschkharan and Cand1igh, 1973) as has been shown in different studies from developing countries. The study 
of Howells et a 1 . (1967) in Kampala (Uganda) demonstrated that the total hydroxyproline/creatinine ratio in malnourished chilAren on adnission $(0.18 \pm 0.10$ mmol) was significantly lower than in normal children $(0.32+0.12)$. After treatment there was a significant rise in the ratio to almost normal levels $10.29 \pm$ 0.14 on discharge). Picon et al. (1965) also established a decreased hydroxyproline excretion in malnourished chilaren in Jamaica as the result of a reduction in the turnover rate of collagen. Creatinine excretion followed a similar pattern, but the decrease and the increase during treatment were not so great.

The neonatal findings in S.G.A. Infants are really confusing (table 2-3) when compared with those obtained during malnutrition in infancy and childhood. Younoszai and Haworth (1968) investigated the daily urinary excretion of total hydxoxyproline in normal term, preterm and S.G.A. (birthweight " 10 th percentile for gestational age) infants on the lst and 3 rd day of extrauterine life. On the first day after birth S.G.A. and normal infants excreted comparable amounts of total hydroxyproline. Though on the 3rd day all infants excreted significantly higher amounts of hydroxyproline than on the lst day, the S.G.A. infants excreted significantly less hydroxyproline on the 3rd day of life In comparison with the preterm and normal term infants.

In a second study Younoszal et al. (1969) established that urinary peptidebound hydroxyproline on the first day of life averaged about 78 of the total hydroxyproline excretion in normal term infants and about 65 in premature infants, Iike the value of Morrow et al. $(1966,1967)$. The mean total hydroxyproline/creatinine ratio of term S.G.A. infants was slightly lower than that of normal term infants on the first day of 11 fe, whereas the ratio was relatively high in preterm infants. On the loth day of ilfe the ratio of the term S.G.A. had increased (1ike that of the normal term and preterm infants), but was now clearly 


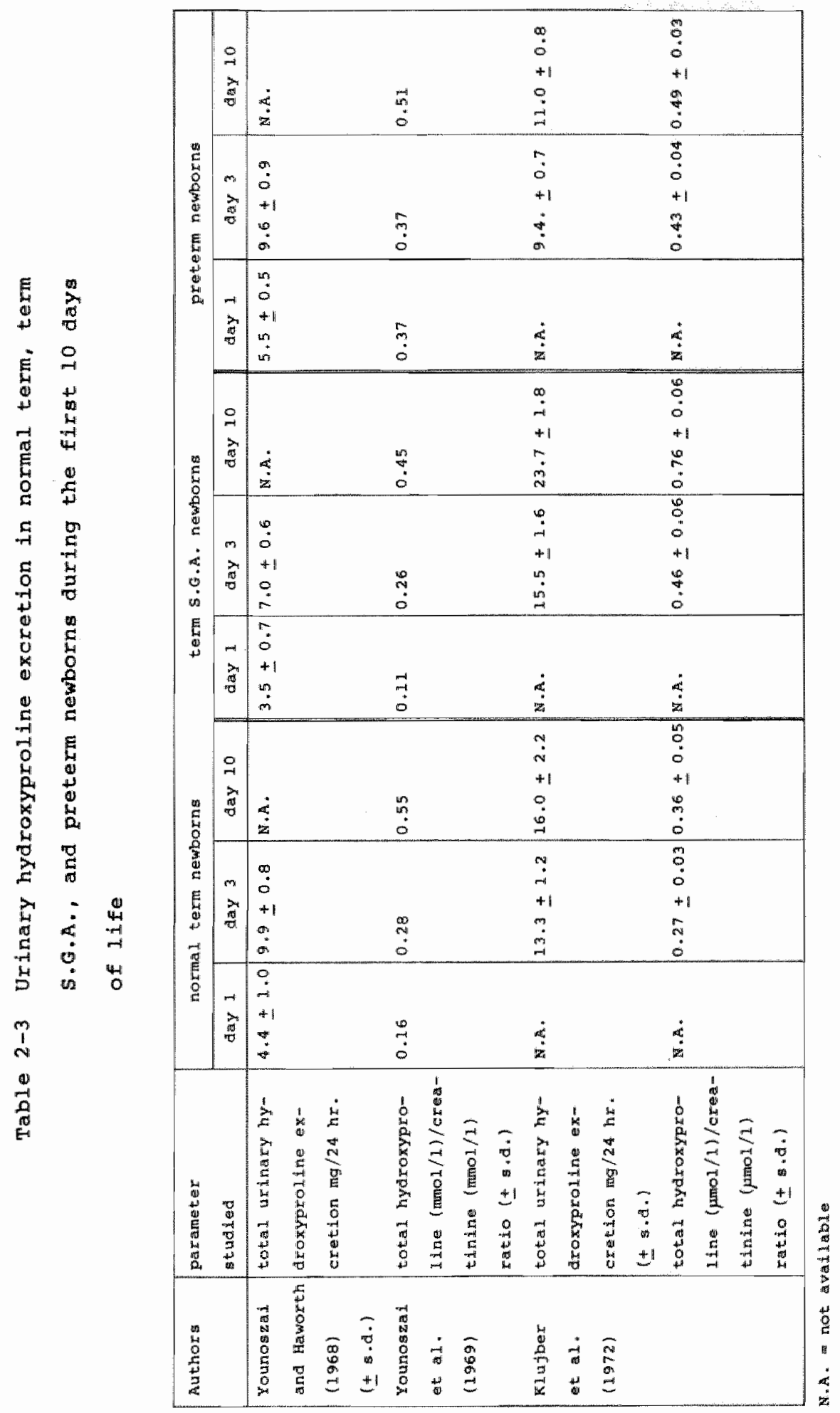


lower than that of the other groups of infanta. "The values on the first day of 11 fe reflect what might be expected for their growth patterns auring the latter days or weeks of pregnancy. S.G.A. infants grow little during this periad, whereas premature infants are growing rapidy. However, the total hydroxyproline/creatinine ratio during the first week of life did not agree very well with the pattern of growth expected during this period of life when S.G.A. infants grow in general more raplaly than normal term or preterm infants.

Klujber et al. (1972) also investigated the mentioned 3 groups of Infant: and found that, except in the preterm infants (gestational age \& 35 weeks and welghing les than 2,2009 ), the daily arimary excretion of total hydroxyproline in normal "term" $(\geqslant 35$ weeks and $>2,200 \mathrm{~g})$ and "term" S.G.A. ( 35 weeks and $(2,200 \mathrm{~g})$ infants was considerably higher on the 3 rd postnatal day than that reported by Younoszal et al. (1968). Their results show that on the $3 r$ day of life S.G.A. Infants demonstrated the highest hydroxyproline excretion " suggesting a rapidly increasing turnover rate of collagen in S.G.A. Infants associated with growth soon after birth. This rapidly increasing phase of growth activAty was also strikingly shown by urinary excretion levels obtained on the loth postratal day: while no significant increase occurred from the $3 r d$ to 10 th day in normally grown term and premature infants, the S.G.A. group showed a highly gignificant $x$ ise in total hydroxyproline excretion whatever reference standard wa used for comparison.

In view of these confusing findings wharton et al. (1971) and Bisenden et al. (1978, 1979) detemined the total hydroxyproline concentration in amniotic fluid at various stages of pregrancy. In their first study (Wharton et a1., 1971) they showed that in normal pregnancy amiotic fluid total hydroxyproline concentration rose to a peak around the 28 th week, before falling steadily 
to term while creatinine concentration was at firt constant and then rose rapidly to maximum values at term the total hydroxyproline/creatinine ratio reached a zenith around 17 week and then fell rapidly. Total hydroxyproline concentrations tended to be lower in those pregnancies producing S.G.A. Infants (birthweight \& loth percentile for gestational agel and those at particular risk of I.U.G.R. As changes in amniotic fluid total hydroxyproline and total hydroxyproline/creatinine ratio seemed to be related to intrauterine growth Bissenden et al. $\$ 1978$ and 1979) also studied if fractionation of total hydroxyproline into its free and peptide components would increase the discrimination of the test. This turned out not to provide more information as there continued to be a considerable overlap with results from normal pregnancies.

Considering the above mentioned relation between anthropometric values (the ponderal index) and skeletal maturity at birth and the unique place of hydroxyproline in collagen turnover whlch mainly takes place in bone, the possibility to use hydroxyproline as a biochemical parameter for (prenatal) diagnosis of intrauterine malnutrition was considered. An investigation of the amount of total hydroxyproline excretion in the first urine of normally grown term infants and term infants malnouribed in utero was started a amiotic fluld was not readily avallable for research purposes and as fetal urine makes a substantial contribution to the composition of amniotic fluld in late pregnancy when the fetal skin has become keratinised. The first urine is more or less comparable with amniotic fluid (Lind et a1., 1972, Houston and Zeig, 1976) and may reflect the nutritional state of the fetus in thero with the advantage of the possiblilty to correlate this with anthropometric values at birth. Earlier studies in this field (Younoszal et a1", 1968 and 1969; Klujber et al. "1972) resulted in conflicting results which may have been due to the 
lack of quantification of the nutritional status of the examined newborng at birth. Therefore in our study the relation between the ponderal index and the urinary excretion of hydroxyproline after birth was investigated.

Wormal term infants and infants affected by intrauterine growth retardation excrete constantly 70-80\% of their total urinary hydroxyproline as peptidebound hydroxyproline during the first week of life (Klelin and Teree, 1966; Morrow et a 1., 1966; Morrow et al., 1967; Younoszai et al., 1969). So total hydroxyprollne excretion can be used as a measure of collagen turnover In the term infant. Allison et al. (1966) showed that as a measure of growth in pogtnatal life the ratio of hydroxyproline to creatinine in a 24 -hour collection was an improvement on the absolute excretion of hydroxyproline, since the ratio partially corrects for body ${ }_{i z e}$ and for differences in renal function. The hydroxyproline/creatinine ratio in 24-hour urine collections correlated well with random urine samples obtained during the same 24-hour period in the studies of Howells et al. (1967) and Younoszai et al. (1969), thus making 24-hour urine collections in our study unnecessary.

In our study (publication I) no correlation between the degree of intraterine malnutrition and the total urinary hydroxyproline /creatinine ratio could be established, indicating that hydroxyproline excretion in the first urine of newborns cannot be used clinically as a measure of intrauterine malnutrition. Indirectly the conclusion of Bissenden et al. (1978 and 1979) was conflirmed: the normal range of urinary hydroxyproline excretion being already wide, growth retardation in utero does not add a measurable and significant decrease to the hydroxyproline excretion in the first urine. 
2.2 The ponderal index as an additional and refined measure to predict the neonatal morbidity of infants malnourished in utero

The perinatal mortality rate of neonates born before the 33 r week of gestation is relatively high. It decreases with advancing gestation and newborns with a gestational age of $38-39$ weeks show the lowest mortality (Lubchenco, 1981). However, it becomes again progressively higher as gestation further advances (Gruenwald, 1964 a). The perinatal mortality rate of S.G.A. infants is substantially higher than the perinatal mortality rate of newborns whose birthweight is appropriate-for-gestational age (table 2-4). This is due to an increased incidence of both stillbirthe and deaths occurring in the first week of life (Papaevangelou et al." $1972)$.

Table 2-4 Perinatal mortality (P.N.M*) rates of S.G.A. and A.G.A. Infants versus overall figures*

\begin{tabular}{|c|c|c|c|c|}
\hline \multirow{2}{*}{ 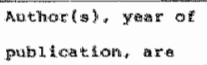 } & \multicolumn{3}{|c|}{ Perinata 1 mortaliny ratio } & \multirow[t]{2}{*}{ Remarks ldefinition of $5.4 . A_{1}$ J } \\
\hline & 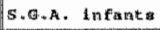 & A.G.A. Inteanto & A.1. Hnfintis & \\
\hline 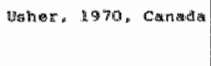 & $129.5 \%$ & $14.3 \% / 00$ & 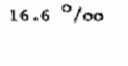 & 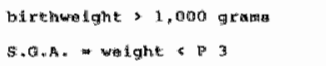 \\
\hline $\begin{array}{l}\text { Popturangelou at } \\
\text { al., 1972, Greece }\end{array}$ & $374.20 / 00$ & $43,3 \% / 00$ & 519. 四 $9 / 000$ & 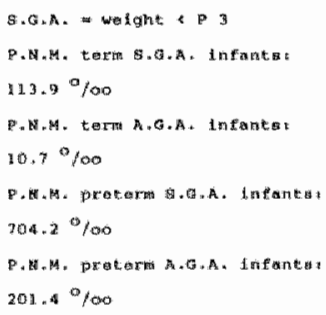 \\
\hline 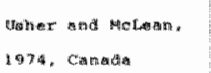 & $100.3 \% / 00$ & $15.9 \%$ & 201,1090 & 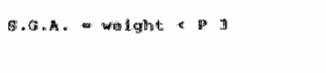 \\
\hline 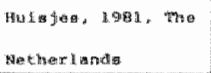 & $7 \% .3 \%$ ron & $15,4 \% / 00$ & $24.20 / 00$ & 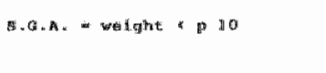 \\
\hline
\end{tabular}

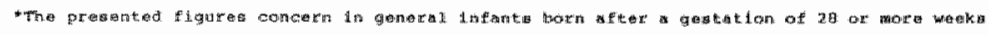

Neonatal mortality rates follow the same pattern as perinatal. mortality rates: the neonatal mortality rate of term S.G.A. infants is higher than the neonatal mortality rate of infants whose birthweight is appropriate-for-gestational age as is illustrated in table $2-5$. 
Table $2-5$ Neonatal mortality (M.M.) rates of term S.G.A. infants versus term A.G.A. Infants

\begin{tabular}{|c|c|c|c|}
\hline \multirow{2}{*}{$\begin{array}{l}\text { Muthor }(\mathrm{s}), \text { yedrof of } \\
\text { publicathon, areal }\end{array}$} & \multicolumn{2}{|c|}{ Weonatal mortedity } & \multirow[t]{2}{*}{ Remark (defindtion) of S.G.A. } \\
\hline & terna $5.6 . A$. Infantis & 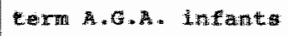 & \\
\hline $\begin{array}{l}\text { Lugro and camady. } \\
\text { 1971, WSA }\end{array}$ & 53.0700 & $12.6^{\circ} / 000$ & $\begin{array}{l}\text { bixthweight } * 1,000 \text { grams } \\
\text { S.G.A. = welght }<\text { p } 3\end{array}$ \\
\hline $\begin{array}{l}\text { Paparingelou et } \\
\text { al., } 1972, \text { areoce }\end{array}$ & $79.9 / 100$ & $5.4 \%$ & S.6.A. welght $\quad$ P 10 \\
\hline $\begin{array}{l}\text { Lubohenco t } 1 \text {. } \\
\text { 1972, UsA } \\
\text { Tejani and Marn, } \\
197 \% \text {, UsA }\end{array}$ & $\begin{array}{l}20.5 \% / 100 \\
16.10 / 100\end{array}$ & $\begin{array}{l}5.0^{0 / 00} \\
8.9^{0 / 100}\end{array}$ & $\begin{array}{l}\text { 8.G.A. = weight }<\mathrm{p} 10 \\
\text { blrthwelght } \$ 1,000 \text { grams } \\
\text { S.G.A. = weight \& } 5\end{array}$ \\
\hline
\end{tabular}

Neonatal morbidity of a significant nature follows the same pattern as mortality (Lubchenco, 1981) which is not amazing as neonatal morbidity of S.G.A. Infants is often the result of fetal disease and/or an insufficient supply line to the fetus in utero (Usher, 1970; Gruenwald, 1974). Tables 2-6, 2-7 and 2-8 present figures about the incidence of the most common clinical problems as a consequence of an insufficient supply line and table 2-9 indicates the incidence of some fetal diseases (congenital infections, congenital malformations and chromosomal anomalies) in S.G.A. infants. Though perinatal morbidity is the worthy successor of perinatal mortality as a yardstick of reproductive adequacy (Huisjes, 1981), rellable figures on neonatal morbiality of S.G.A. Infants in the Netherlands are not readily available and tables $2-6$ till $2-9$ have been composed of many different tudie in this field. 
Table 2-6 clinical problems of the S.G.A. infant: I Asphyxia, acidosis and hypothermia

\begin{tabular}{|c|c|c|c|c|}
\hline Fubletion & 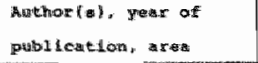 & 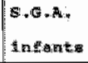 & 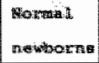 & 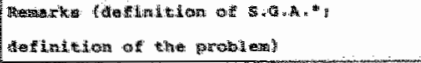 \\
\hline Defey & 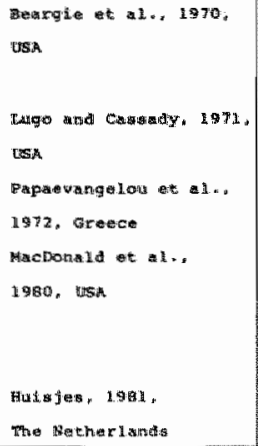 & 3.78 & $\begin{array}{l}0.88 \\
0.36 \%\end{array}$ & 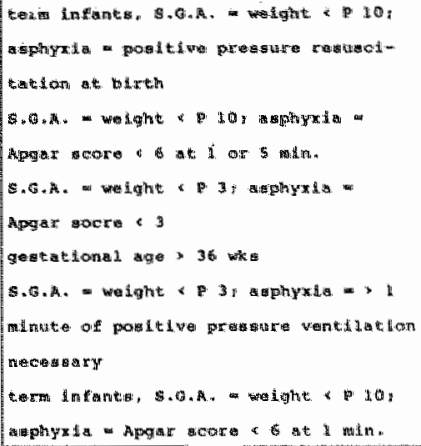 \\
\hline Acictions fit & 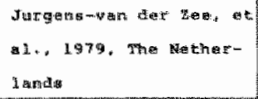 & 19.00 & 0.08 & 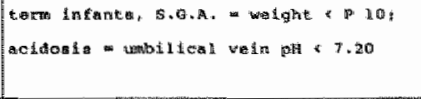 \\
\hline Hiypocthe 5 . & 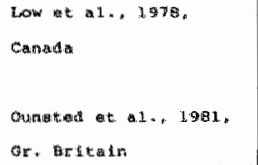 & 308 & 48 & 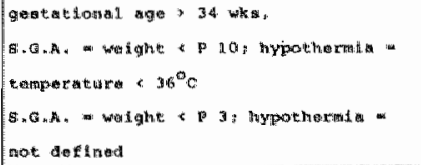 \\
\hline
\end{tabular}

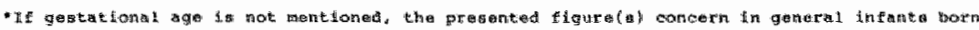
atiet gestetion of 28 ox more watk

Table 2-7 Clinical problems of the S.G.A* infant: II Hypoglycemia

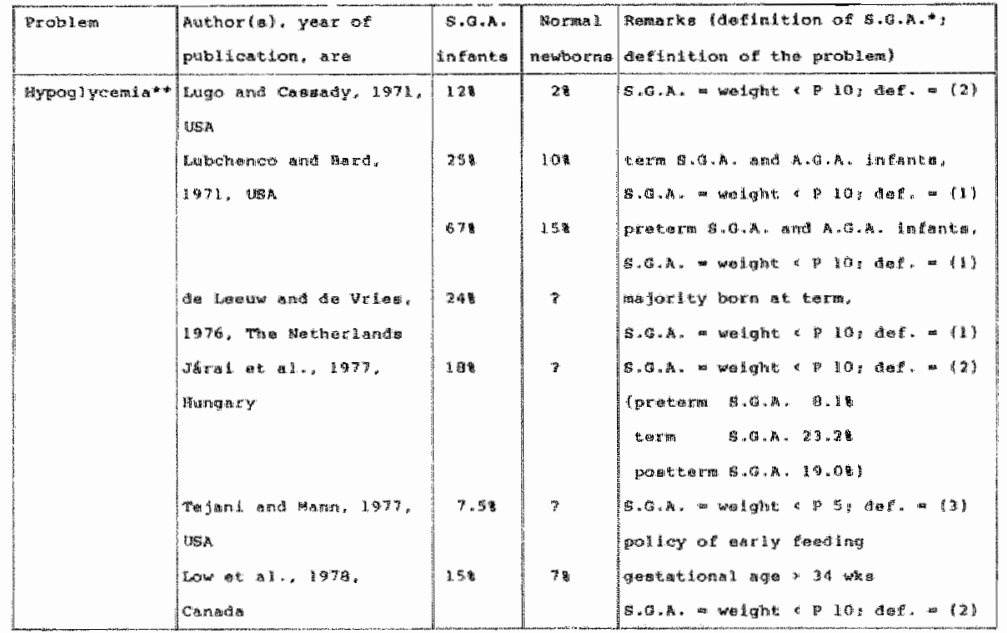

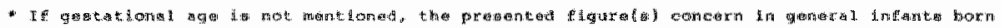

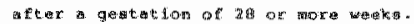

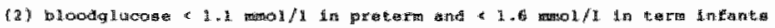

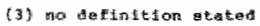


Table 2-8 clintcal problems of the S.G. A. Infant: II Polycythemia/hyperyiscosity, hyperbili rubinemia and tranient respiratory distress

\begin{tabular}{|c|c|c|c|c|}
\hline Protiden: & $\begin{array}{l}\text { Buthor }(\theta), \text { year of } \\
\text { publication, area }\end{array}$ & $\begin{array}{l}\text { S.G.A. } \\
\text { Infranta }\end{array}$ & $\begin{array}{c}\text { Norma } 1 \\
\text { newtions }\end{array}$ & $\begin{array}{l}\text { Remarks (aefuition of S.G.A * } \\
\text { defintion of the problem) }\end{array}$ \\
\hline \multirow{2}{*}{$\begin{array}{l}\text { Polycythordef } \\
\text { hyperviseos- } \\
\text { 1ty * }\end{array}$} & $\begin{array}{l}\text { Lugo and Camady. } \\
1971 . \text { UgA }\end{array}$ & $1.2 \%$ & 28 & S.G.A. = welght o P 10; def. $=(1)$ \\
\hline & $\begin{array}{l}\text { wirth et a1., } 1979 \text {, } \\
\text { USA } \\
\text { Hakangon and or, } \\
1980 \text {, Ush } \\
\text { Stevens and with, } \\
1980, \text { USA }\end{array}$ & 17.78 & $4-58$ & 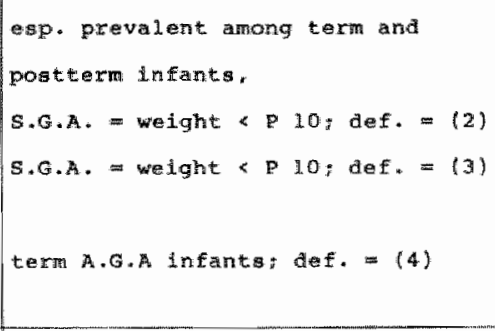 \\
\hline $\begin{array}{l}\text { Myperbial- } \\
\text { rubinemi }\end{array}$ & $\begin{array}{l}\text { Low tet a } 1978, \\
\text { Canada }\end{array}$ & 48 & $2 \%$ & $\begin{array}{l}\text { gentational age }>34 \text { wks } \\
\text { S.G.A. = weight \& P } 10\end{array}$ \\
\hline $\begin{array}{l}\text { Mrandient } \\
\text { respiratory } \\
\text { distresa * * }\end{array}$ & $\begin{array}{l}\text { Low et a } 1 ., 1978 . \\
\text { Canada }\end{array}$ & 6 & 28 & $\begin{array}{l}\text { geftational age } \$ 34 \text { whs } \\
\text { S.C.A. = watght } \times 10\end{array}$ \\
\hline
\end{tabular}

- If chestationall age is not mentioned, the presented figure(s) concern in general infants born after a gratiation of 28 or more weeks.

* Definitioma ugea:

(1) capillary haematocrit y 708

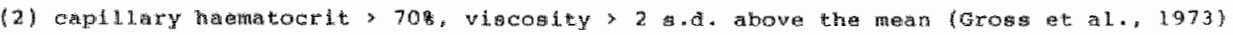

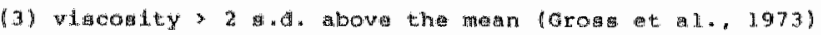

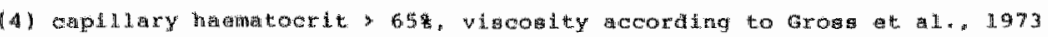

* Defined as requixing phototherapy or an exchange tranefusior

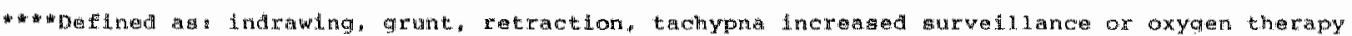


Table 2-9 Congenital infections, congenital anomalies and ohromosomal abnormalities* in S.G.A. infants and in the general newborn populatione

\begin{tabular}{|c|c|c|c|c|}
\hline Problem & $\begin{array}{l}\text { Author }(3) \text {. year of } \\
\text { publication, area }\end{array}$ & S.G.A. & $\begin{array}{l}\text { Dveral } \\
\text { flgure }\end{array}$ & Remake (decinition of $s . \mathrm{a} \cdot \mathrm{A}$. ) \\
\hline $\begin{array}{l}\text { Congenital } \\
\text { malforma- } \\
\text { tilons and } \\
\text { chromosoma } 1 \\
\text { anomalies }\end{array}$ & 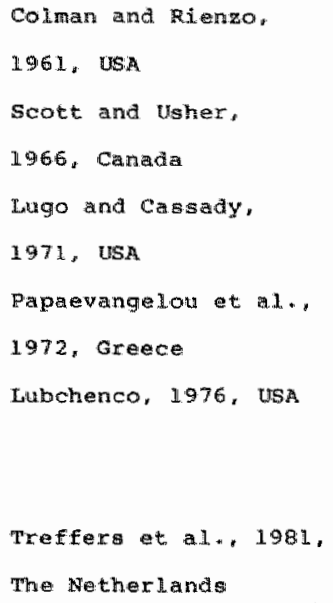 & $\begin{array}{l}B .1 \text { 중 } \\
11.18\end{array}$ & $\begin{array}{l}3.7 \% \\
3.3 \% \\
3.3 \% \\
0.21\end{array}$ & 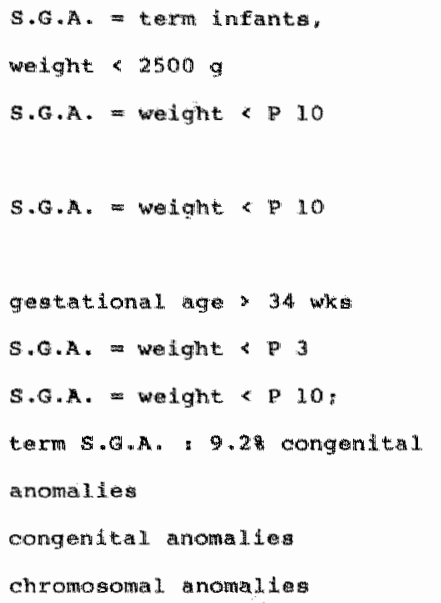 \\
\hline $\begin{array}{l}\text { Congenital } \\
\text { Infections }\end{array}$ & $\begin{array}{l}\text { Beargíe et al. , } 1970 \text {, } \\
\text { UsA } \\
\text { Alford, 1971, USA }\end{array}$ & 2.28 & 0.58 & 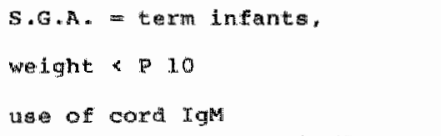 \\
\hline
\end{tabular}

*As the figures of congenital anomalies and chronogomal abnomalities are afficult to separate in the different reports, they are presented together.

Normal labour may severely compromise the S.G.A. infant (Lin et a1., 1980) when intrauterine hypoxia (Usher, 1970) due to an insufficient supply is present. Table $2-6$ shows that neonatal asphyxia and acidosils tend to be more common in the S.G.A. Infant. During the asphyxial insult the S.G.A. Infant frequenty passes meconium in utero (Fujlkura and Klionsky, 1.975) and develops a gasping fetal breathing pattern (Dawes, 1974) resulting in the aspiration of meconium with resulting apiration pneumonia which may be complicated by pneumothorax and pulmonary haemorrhage (Bacsick, 1977). The overall incidence of meconium aspiration syndrome in live-born infants amounts to 1-38 (Brown and Gleicher, 1981), but the exact incidence in S.G.A. Infants is not well known.

The relatively large surface area with decreased insulation 
due to markediy diminished subcutaneous fat tissue may result in excessive heat loss with hypothermia in the S.G.A. infant (sinclait, 1970), table 2-6.

The high frequency of hypoglycemila in S.G.A. infants (table 2-7) has been attributed to a deficiency of depot fat (Usher and McLean, 1974; Widdowson, 1974 and b; Roord and Ramaekers, 1978), a deficient gluconeogenesis (Haymond et al., 1974; Kollée et a1.. 1979; Kollée et al., 1980) and a diminished glycogen storage at birth (Wigglesworth, 1967; Hi11, 1974).

Hyperviscosity due to polycythemia is clearly an exaggerated response of the S.G.A. infant to intrauterine hypoxia with resultant erythropoletin production (Finne, 1966). Hypoxia, acidosis, hypothermia, and hypoglycemia may lead to decreased deformability of red blood cell membranes (Bergquist, 1974) and increase the blood vigcosity in addition. The incidence of hyperviscosity in healthy term A.G.A. infants (about 48, see table 2-8) is considerable. This led recently to a discussion (Van der Elst et al., 1980) about the need to perform (partial) exchange transfusions (Kontras, 1972; Mentzer, 1978) in all these cases. In the presence of clinical symptoms most authors tend to take measures to reduce blood viscosity in order to prevent inadequate thasue perfusion and sludging.

Intrauterine growth retardation does not affect the physiologic maturation of fetal organs which develops according to geatational age. The incidence of hyperbilirubinemia and the respiratory alatress syndrome in the term S.G.A. infant is only slightly above normal (table 2-8): hyperbilirubinemia occurs more often in cases of hyperviscosity and (transient) respiratory distress in cases of asphyxia. The susceptibility to infection of the S.G.A. Infant in the neonatal period is increased (Papaevangelou et al., 1972), probably as a result of defective humoral (Papadatos et a1., 1969; Chandra and Matsumura, 1979) and 
cellular immunity (Ferguson, 1978).

Congenital infections, chromosomal and congenital anomalies are especially encountered in S.G.A. infants (table 2-9). The birthweight of siblings is of clinical significance: 80 of infants with rubella-embryopathy have a birthweight below the range of variability of birthwelght within the sibship but only 41-46. of them wauld have been considered small-for-gestational age using empirical charts (Turner, 1971). Except this comparative method of considering birthwelght (in the multigravida) to assess retardation of intrauterine growth, clinically silent intraterine infections can be established by estimating cora IgM levels (Alford et al. 1967; Tympner, 1971; Haider, 1972) though Matthews and $\mathrm{O}^{\prime H e}$ Hihy (1978) recently remarked that determinam tion of cord IgM in S.G.A. Infants did not help significantly in diagnosis of infections.

Not all S.G.A. Infants will present signs of above mentioned morbidity patterns in the early neonatal period and the incidence of morbidity will also depend on the duration of the gestational age, and the maturity of the infant. About 358 of the S.G.A. infants escape al1 problems at delivery and in the neonatal. period (Ounsted et al., 1981), resume growth soon after birth. and can be discharged early. The majority suffers from one or more of the above mentioned (causative interrelated) complications which may lead to longterm morbidity. To facilitate the recognition of those term S.G.A. Infants who are at high risk of neonatal complications, we turned to the ponderal index as a measure to quantify intrauterine malnutrition. In two studies we tried to establish if the pondexal index might be helpful at birth to select those growth retarded infants at high risk. The first one (publication II) reports on the nutritional status (quantified by birthweight for gestational age and by the ponderal index) and the neonatal morbidity of a group of 500 term 
newborns. The second paper (publication III) presents the morbidity pattern of 46 severely S.G.A. term infants birthweight \& $P$ 2.3 for geatational age) according to their nutritional status (using again the ponderal index). Both publications point to the fact that especially alsproportionally grown term (S.G.A.) infants are at high risk of neonatal complications in comparison with proportionally grown term S.G.A. Infanto. The ponderal index turned out to be a useful measure to predict neonatal morbidity (In addition to the usual classification according to birthweight for gestational age).

Publication II demonstrates that nearly 408 of the term S.G.A. infants (infants whose birthweight is below the loth percentile for gestational age on the kloosterman curves) were clearly disproportionally grown as they had a P.I. below the 10th percentile of Miller and Hassanein (1971). But of the infants whose birthweight was above the loth percentile for gestational age 8.1\% also had a ponderal index below the 10 th percentile and were disproportionally grown. Term infants with a birthweight and a P.I. below the 10th percentiles showed more often neonatal problems (like asphyxila, acidosis, hyperviscosity, hypoglycemia, and hypothermia) than proportionally grown term S.G.A. infants. Disproportionally grown term infants with a birthweight above the loth percentile also had a greater morblalty than proportionally grown term infants with a birthwelght above the 10 th percentile, though theix morbidity remained below that of disproportionally grown term S.G.A. infants.

of the 46 term, severely S.G.A. infants (birthweight \& $\mathrm{P} 2.3$ for gestational age on the Kloosterman curves) in publication III 23 (508) were disproportionally grown (P.I. \& P 3 according to Miller and Hassanein, 1971), indicating that the percentage of disproportionally grown infants increases when birthweight for gestational age falls off. Whereas in publication II 528 of 
S.G.A. infants with a birthweight * loth percentile escaped without neonatal morbidity, this percentage was lower among the S.G.A. Infants with a birthweight < 2.3 percentile in publication IIr. In the series of ounsted et a1. (1981) only 35 of the S.G.A. infants (birthweight \& 3 rd percentile) escaped any perinatal problems, but that study was performed over a long period (1964 - 1977) during which perinatal care progressed quickly.

As there occurs a higher incidence of neonatal norbidity in severely S.G.A. infants than in moderately S.G.A. infants, the incidence of neonatal morbidity increases when the ponderal index decreases (and disproportional growth prevails). So both underweight-for-gestational age and underwelght-for-length (small ponderal index, disproportional growth) predispose term infants. to neonatal morbidity.

\subsection{Postnatal growth of newborns affected by intrauterine malnutrition}

At birth the size of a term infant correlates more with the size of the mother than with the size of the father (Tanner et al.. 1956) and term male newborns are in general longer, heavier, and have a greater head circumference than female newborns (Usher and McLean, 1969; K1oosterman, 1970). The faster 1ate fetal growth of the male fetus can be explained by testosterone production from the testioles after 32 weeks of gestation (Smith, 1977). This accelerated growth of the male as compared to that of the female continues for 3 to 6 months ater birth (Smith, 1977). Thereafter the serum testosterone levels are low in both sexes and there is no appreciable sex difference in growth rate until the advent of adolescence. Given an adequate environment, the infants shift after birth from a growth rate that is predominantly determined by maternal factors to one that is increasingly related to its own genetic background, as exemplified by the mid-parental height 
(5nith et a1, 1976). For about two third of normal infants, the linear growth rate shifts auring the first 12 to 18 months of 1ife. The number shifting upward and the number shifting downard in growth rate are about equal (Smith et al. 1976). Infants who are relatively small at birth but whose genetlc background indicate latger bize begin their acceleration toward the new growth rate aon after birth, and they have achieved a new channel of growth by 4 to 18 months of age (Smith et a1. 1976). Those who are relatively large at birth but whose genetic background is for smaller bize tend to maintain the prenatal growth rate for several months before beginning their deceleration into a lower growth channel, which is usually achieved by 8 to 19 months of age (Smith et al., 1976). Though at birth first-born term newborns are smaller than average, by d year of age they have usualIy whifted in growth rate and are sightly longer than subsequent offoprings (Smith, 1977).

Whereas in infancy major ghifts in growth rate occur, by the age of 18 months to 2 years the child enters an era of stable growth. Already toward the latter part of the first year, there is a gradual diminution in growth rate and from 2 years onwards the child grows falrly consistently at a rate of 5 to $7.5 \mathrm{~cm}$ yearly. Adolescence is the period of gonadotrophin-induced maturation and linear growth acceleration. Most Iinear growth has been achleved by the age of 18 years, with an average of $1 \mathrm{~cm}$ in further growth taking place between 28 and 21 years (Roche and Daw11. 1972).

Some of the numerous factors affecting the rate of postnatal growth and the ultimate size of a child have been mentioned already. However, numerous factors are known to play a role: genetic factors (the mid-parental height), genetic sex aifferences (due to the presence of the $Y$ chromosome), genetic raciall differences (Asiatic children tend to be smaller than either the 
black or the white child; Barr et al " 1972), soeial class or socio-economic status, parity, season (in England chllaren grow faster in the summer than in the wintex: Marshall, 1971), nutiltion (inadequate intake, malabsorption), environment (neglect. abuse), endocrine factors (testosterone, estrogens, pltuitary growth homone and somatomedin, thyrold hormonel, chronic aiseases (such as cardiac defects, renal dysfunction, chronic serious infectious disease, metabolic disorders), and mental deficiency (Doorn, 1967).

The somatic postnatal growth of S.G.A. newborns will depend on the etiology of the intrauterine growth retardation the extent of associated perinatal insults, and the above mentioned numerous factors. Infants with decreased growth potential such as those with chromosomal disorders (1ike the Turnex syndrome), with fetal intoxications (like the fetal alcohol syndrome), with congenttal malformations (1ike chondrodysplasia), or with congenital infections (1ike rubella), can be expected to grow less well after birth as the small size at birth is often due to a deficient number of cells. But in the mafority of S.G.A. Infants no cause can be identified which explains their growth retardation in utero (see 1.3).

When one surveys the literatufe dealing with the postnatal growth of S.G.A. infants, one finds a surprising dearth of good studies. Many early papers are invalidated by the lack of adequate assessment of gestational age leading to the failure to alstinguish $5 . G . \mathbb{A}$. infants from premature A.G.A. infanta (Dubowitz, 1974). Therefore only studies performed since the early seventies are worthwhile to review.

One of the best studies has been that of Fitzhardinge and steven (1972 a). They did a follow-up study of 96 Si.G.A. singleton nfants born in Montreal (Canada) in the years 1960-1966. The 
infants in the study had a gestational age of greater than 38 weeks, birthwelght at more than 2 standard deviations below the expected weight for gestational age (equivalent to a weight below the 3rd percentile), and no obvious cause for the underweight in the wey of congenital malformations, infections, chromosomal disorders and so on. Disproportionate and proportionate I.U.G.R. were not distingulshed: though all the infants were more than 2 atandard deviations below the expected weight at birth, 67 were more than $2 \mathrm{~s} \cdot \mathrm{d}$. below the expected length and 76 below the expected head circumference. At the age of 6 months the average weight and length for the group were between the 10th and 25 th percentile, but at six years $35 \%$ were still below the 3 rd percentile in weight and height and only 8 obove the 50 th percentile. A comparison at follow-up of the 45 infants whose length at birth was below the 3 rd percentile with the rest of the group (above the 3rd percentile at birth) showed no significant difference between the two, with both groups being below the 50th percentile. Assessment of growth velocity by 6 -monthly increments showed that those S.G.A. infants whose height eventually exceeded the $3 \mathrm{rd}$ percentile had a greater velocity in the first 6 months after birth than the remaining infants, but no difference in velocity after 6 months. Correlation of the growth retardation at follow-up with various maternal and enviromental factors showed a positive correlation with socio-economic status only.

The general picture which emerges from the study of Fitzhardinge and steven (1972 a) and other studies about the postnatal growth of term S.G.A. infants (Babson, 1970; Cruise, 1973; Dubowitz, 1974; Smolders-de Haas, 1974; Martel1 et al., 1978; Davies et al., 1979) is that the rates of weight gain, length and head circumference growth of S.G.A. infants are higher than in those of A.G.A. infants during the first 6 months after birth. Thereafter (none of these studies provides information about 
growth after the age of 6 years) the differences in growth rates between S.G.A. and A.G.A. infants are not significant anymore. This accelerated growth is called "catch-up" (but it does not refer to the ultimate size attained). Studies about the postnatal growth of S.G.A. Infants whose gestational age is not stated (Ounsted and Taylor, 1971; Ounsted and Ounsted, 1973; Chamberlain and Davey, 1975; Chamberlain and simpson, 1977) and which probably describe a mixture of preterm and term 5.G.A. infants, confirm the described general picture. An interesting feature ls that head circumference reaches its maximum rate of growth earlier than weight and length (Fujinura and Seryu, 1977; Davies et a1., 1979). As head circumference is closely related with brain weight (Cooke et al., 1977), the recovery of intrauterine growth retardation of the brain seems more important for the S.G.A. infant than the recovery of his weight and length growth deficit. Another interesting fact is that in animals whose maturity at birth is comparable with humans (like guinea pigs), the rate of postnatal growth is also related to the size at birth (Widdowson, 1974 b). If rats are atarved during the 'brain growth spurt. (see 2.4), a critical period of development during the first weeks of life, the subsequent rate of growth is diminished despite the avallability of a liberal supply of food and at maturity these animals have a relatively small size (Widdowson and McCance, 1963; Winick and Moble, 1966).

Davies et al. (1979) studied the somatic growth in the first 3 months after birth of disproportionally growth term S.G.A. newborns (with a ponderal index below the 3 rd percentile) and showed that these newborns gain more rapidiy in welght, length and head circumference than more proportionally grown term S.G.A. Infants (with a ponderal index between the 10th and 50 th percentile). In both groups rates of growth in each of the 3 months after birth were greater than in term A.G.A. infants. Furthermore Davies and 
Beverly (1979) demonstrated that on average S.G.A. infants increase their weight xelatively more than their length, so that by the end of the first year they have simar body proportions as A.G.A. Infants. Whereas at birth the average ponderal index of this group of $\$$.G.A. infants was relatively low in comparison with A.G.A. Infants, at 12 months of age the difference was not signifleant anymore. However, disproportionally grown term S.G.A. infanta continue to be shorter and Iighter than A.G.A. infants at 1 year of age (Davieg and Beverly. 1979). Chamberlain et al. (1975 and 1977 ) remarked that S.G.A. Infants were often relatively underweight-for-length at 22 and 42 months of age, but they did not quantify this using a weight-length ratio like e.g. the ponderal Index and did not provide information about disproportionate and proportionate I.U.G.R. at birth among the S.G.A. infants followed-up in their study.

Gruenwald (1974) supposed that I.U.G.R. In the later weeks of pregnancy (i.e. disproportionate I.U.G.R.) would result in complete catch-up growth after birth. The available literature dealing with this subject is scarce and provides only useful information about the postnatal growth of disproportionally grown S.G.A. infants during the first year of life (Davies, 1980 and 1981). But it indicates that the hypothesis of Gruenwald may not be valid. To finvestigate the ultimate outcome of this subgroup of S.G.A. Infant: we followed-up a group of disproportionally grown term infant till the age of 3 years, when they will have reached thell definite channel of growth (Smith et a1." 1976). Strict selection criteria were applied to avold confounders influencing postnatal growth. Only term born Caucasian singletons free from additional perinatal complications (like artificial delivery. asphyxia, acidosis, hypoglycemia, hyperviscosity, hyperbilirubinemia, hypothermia, and respiratory difficulties) and from fetal 
aiseases (congenital malformations, infections, chromosomal anomalies) were sellected. Disproportionate I.U.G.R. Was defined by a birthweight below the loth percentile for gestational age (Kloosterman, 1970$)$ and a ponderal index $\left(100 \times \mathrm{W} / \mathrm{L}^{3}\right)$ below the loth percentile for gestational age of Lubchencc et al. (1966). The loth percentile of the ponderal index curves of Lubchenco et al. (1966) corresponas to the 5 th percentile for gestational age of the ponderal index curves of Miller and Hasanein (1971).

At 3 years of age (mean age $38 \pm 3$ months) we reviewed their somatic growth in combination with a group of healthy controls matched for age, sex, birth rank, and social class. The average height of the parents of the two groups was comparable, excluding genetic variations. Weight, length, head circumference, skinfold, and skeletal maturity were used as parameters to establish if asproportionate intrauterine growth results in complete catch-up growth over the first 3 years of life. Skinfold measurements and the estimation of skeletal maturity have rarely been used during follow-up studies of S.G.A. infants, and were included in the examination proforma as these two measures proved to provide essential information about the nutritional status at bixth (Roord et al., 1978).

Standard physical measurements were obtalned ghortly after birth by Roord and Ramaekers (1978). Welght wa estimated with the newborn fully unclothed. The crown-heel distance was determined with the baby supine, with both legs extended and lying on a measuring scale with a fixed head-plate and a movable footplate (neonatometer). Miller and Hassanein (1971) found variations in crown-heel measurements not exceeding 2 (the influence on the ponderal index of a variation in length of \pm 1 would be $\pm(1-0.9706)= \pm 3$ of the index $)$. Head circumference was measured 24 hours after birth using a non-stretchable tape placed from the maximal occipital prominence around to the area juat 
above the eyexbows. Length was recorded until 18 months of age, whereafter helght was obtained using a stadiometer. At follow-up weight mas measured with the child largely unclothed and head circumference measurements were performed as in the neonatal period. These measurements were obtained as accurately as possible by several observers, all of whom had been carefully taught the technique of measurements and were unaware of the category. A high degree of accuracy and consistency could be achieved. At 3 years of age all physical measurements were performed by the writer using the game techniques and unaware of the category.

Rublication IV shows that despite the presence of postnatal catch-up growth in the first 6 months after birth the term infants who were disproportionally growth retarded at birth continued to be underweight-for-length and lean (relatively small skinfold values) at the age of 3 years. The upward shift in length and head circumference was greater than for weight.

Publication $V$ indicates that whereas at birth the infants malnourished in utero had a significant retardation in skeletal maturity, at 3 years of age their average skeletal maturity approached that of the healthy controls. However, those intrauterine malnourished children with a length below the national 10 th percentlle t1ll showed at 3 years of age a retarded skeletal. growth in comparison with those who had reached a length above the loth percentile for age.

\subsection{Developmental aspects of intrauterine malnutrition}

In a recent large-scale follow-up study Neligan et al. (1976) demonstrated that both children who are "born too soon' and those who are "born too small" show some jupaiment of performance when they reach school-age, and that those 'born too small' are at a greater disadvantage and appear less likely to show normal development. Their results point to the fact that when a child is 
"born too soon" "but with an otherwise normal intrauterine growth pattern, he will continue to develop normally if he can be protected from the dangerous neonatal complications of premature birth, and can be kept in an adequate nutritional state to continue his normal pattern of growth. But, when a child's growth pattern has already been impaired in wtero, his whole subsequent development may be significantly impaired in a manner which cannot be remedied by improvements in neonatal care. Except biological and clinical factors, enviromental factors, and especially the quality of the mother's care of her child, are of great importance (Drillien, 1970; Neligan et al., 1976). Desplte this latter feature the above mentioned conclusions hold out.

Gruenwald (1963) first called attention to the fact that whereas the liver, spleen, adrenals and thymus are severely reduced in size in S.G.A. infants, the brain appears to be the least affected. The human brain initiates the period of rapid weight gain during the last half of fetal life, with a peak near the time of birth which then decreases over the first year of postnatal life (Dobbing and Sands, 1979). There are two major periods of brain cell multiplication: one the neuroblasts, from 15-20 weeks of gestation and one, the glia, which commences at about 25 weeks of gestation, this second period probably end in the second year after birth (Dobbing and Sands, 1970). Approximately two-thirds of the human brain cells, as represented by DNA, accumulate prior to birth (Winick, 1968). The 'brain growth spurt" may be a period of enhanced vulnerability to nutritionall. restriction (Dobbing and Sands, 1979). Timing in relation to birth, severity and duration of intrauterine growth retardation will determine the final growth limitation of the brain. In guinea pigs (who like humans initiate the brain growth spurt in uterol adequate postnatal nutrition offsets some, though not all of the biochemical changes resulting from intrauterine growth 
retardation: especilly the quantity of DNA in the cerebellum remalned reduced at reaching maturity (chase et al., 1971). Thomas et a. (1979) demonstrated by means of stereological analysis of the brains of rats undernourished from birth (within the brain growth spurt) a deficit in the synapse to neuron ratio. The quetion arises if in human belngs the brain changes produced by intrauterine growth retardation are functionally important and reverible during the period of nutritional rehabilitation after birth *

The combination of prematurity and S.G.A. might lead to higher incidence of handicap than one of these factors alone. Commey and Fitzhardinge (1979) established major neurological handicaps in 498 of a group of premature S.G.A. infants followed-up for two years after birth. Major neurological problens (1ike cerebral palsy and epilepsia) and hearing and vision disturbances are uncomron in 5.G.A. infants born at term, but evidence of minimall brain dysfunction is present in 25 and speech deficits in about 30\% (Fitzhardinge and Steven, 1972 b) at the age of 4-6 years. Though intelijgence quotient scores do not differ appreciably From A.G.A. Infants (Babson and Kangas, 1969; Fitzharainge and Steven, 1972 b) about one-third of the S.G.A. infants are failing In chool (Fitzhardinge and steven, 1972 b; Parkinson et al.. 1981) where behawlour problemg are more often encountered than normaly (Parkinson et al." 1981). From the studies of Fitzhardinge and steven $(1972$ and b) the remarkable Feature emerged that in a group of term S.G.A. Infants selected by birthwelght only the severity of intraturine growth retardation (related to welght deficit at birth) did not show a correlation with ultimate growth achievement and with subsequent developmental ontcome. This observation induced the question if a short period of intrauterine growth retardation (recognizable at birth as disproportionate growth) might lead to an impaired postnatal 
development.

To answer this question we thoroughly revilewed at the age of about 3 years a group of chliaren who presented disproportionate I.U.G.R. at birth (synonyms: intraterine malnutrition, subacute fetal distress). The children in the study group and the controls (see the selection criteria in 2.3 ) whose growth parameters have been discussed in publications IV and $V$ were subjected to an assessment of their behaviour, neurological functioning, and language development according to age-appropriate proformata. Behaviour and language can be considered as complex cerebral. fumctions which develop and extend quickly over the first years of life. Clinical experience suggests that cerebral dysfunction is ofter accompanied by behaviour problems and also by language delay. Dysfunction of the nervous system was substantiated by assesment of the neurological development. The values of behaviour and language development were considered as possible additional indicators of cerebral dysfunction. Except the fact that this subgroup of S.G.A. infants (disproportionate I.U.G.R.) had not yet been studied in this way, the children in our study benefited in contrast with the above mentioned studies fully of the introduction of intensive prenatal and postnatal care as well as of early and high-caloric nutrition lde Leeuw, 1972: Brandt, 1981).

Publication VI shows the results of the behaviour and neurological asseasments and publication VII provides the language achievements in relation to the data presented in publication VI. Behaviour was studied using the behaviour screenling questionaire (B.S.Q.) of Richman and Graham (1971), the items of problem. behaviour concerned: 1) eating, 2) sleeping, 3) soliting, 4) activity, 5) concentration, 6) relations with other children, 7) attention seeking and dependency, 8) difficulty to manage, 9) tempers, 10) mood, 11) worries and 12) fears. As parental reports 
on specific items of behaviour might be inaccurate, a behaviour abserwtion report (B.O.R.) was composed of all children. This consisted of 8 items: 1) activity, 2) concentration, 3) attention seeking and dependency, 4) negativism, 5) insistency, 6) destructivity and aggression, 7) fidgetiness and 8) fears.

Neurological dysfunction was studied using the 26 items suitable for children of 3 years of age of the examination proforma for minor neurological aysfunction of Touwen (1979).

The Reynel1. Developmental Language Scales (Reymell, 1969) were used to test language and the results were rellated to the assessment of behaviour and neurology.

Both problematic behaviour and neurological dysfunction occurred more frequently (in about one third of the children) in the group of disproportionally grown infants. Furthermore both verbal comprehension and expresslve language were significantiy less developed in infants malnourished in utero. A firm relation coula be established between language delay and behaviour problems, a feature well known to speech therapists (Baker et al., 1980 ; Mattison et al. 1980). Language delay and neurological dysfunction were als interrelated and this applied also to neurological aysfunction and behavioux problems.

These atudies point to the fact that disproportionate intrauterdne growth retardation often results in signs of brain dysfunction at the age of 3 years and that behaviour problems, neurological dysfunction and language delay are comparable as indicators of brain dysfunction at that age. Disproportionally grown newborns turned out to be a group at high risk for deve1opment delay. 


\section{Summary}

Already in the early sixties it was emphasized that not all low birthweight infants (less than 2,500 gram) were born prior to term. Ensuing studies showed that about one third of all infants of low birthweight are small-for-gestational age (S.G.A.) and have experienced intrauterine growth retardation. Whereas the follow-up studies of low birthweight infants born during the $1950^{\prime} \mathrm{s}$ and early $1960^{\prime} \mathrm{s}$ demonstrated a significant incidence of handicaps, the results of subsequent studies with improved perinatal care indicated an increasing number of surviving children. It is now recognized that a substantid number of the infants of these early studies were of low birthweight because of growth retardation rather than preterm birth and that the prognosis of sinal-for-gestational age infants is different from the prognosis of preterm infants.

At present intrauterine growth retardation is generally defined as a birthwelght below the 3rd, 5th or loth percentile for a given gestational age. However, this definition characterizes a variety of conditions which all ultimately affect fetal growth. The etiological clasification of fetal deprivation aistinguishes adverse conditions "intrinsic" to the fetus and/or placenta (11ke chronosomal anomalies) and 'extrinsid' factors acting on the fetus and/or placenta like intraterine infections and hypertension(toxemia). Clinically, growth retarded newborns can be divided into those with obvious fetal diseases (chromosomal anomalies, congenital malformations and infections and those without. Daily practice has shown that in the vast majority of S.G.A. infants no obvious cause can be identified which may explain their retarded growth.

If genetically small infants are left out of consideration the growth retarded newborns without fetal diseases can be subdivided 
according to the timing and duration of the intrauterine growth retardation. When the growth retardation started early in the third trimester (and has a duration of months) the infant will be proportionally mall with respect to weight, length and head circumference (proportionate intrauterine growth retardation, or chronic fetal distress according to Gruenwald).

A second type of intrauterine growth retardation laisproporthonate intrauterine growth retardation, or subacute fetal distress according to Gruenwald) reflects disproportionate growth: weight is more affect than length and head circumference as the factorg modifying fetal growth are operative only in the last weeks of pregnancy and the weight-length ratio will be reduced. Disproportionate intrauterine growth retardation for "intrauterine malnutrition' as these infants appear 'wasted' at birth) and proportionate intrauterine growth retardation can be separated objectively by quantifying the degree of disproportion using a weight-length ratio like the ponderal index $\left(100 \mathrm{x} \mathrm{W} / \mathrm{L}^{3}\right)$.

In the presented papers the ponderal index was used at birth to quantify the nutritional status of term infants affected by intraterine malnutrition.

In 2.1 and publication I the possibility is considered to use the urinary total hydroxyproline excretion as a biochemical parameter for the diagnosis of "intrauterine malnutrition. This weemed concelvable as urinary hydroxyproline excretion is known to reflect the growth rate in early infancy and in young chilaren, as hydroxyprolime is a reliable lndex of bone collagen metabolism, and as skeletal growth is retarded in intrauterine malnutrition and correlates in a highly significant manner with the ponderal index. In this study the severity of the malnutrition was quantified by the deviation of the P.I. from 'normal'. By chemical analysis the total hydroxyproline excretion in the first urine sample passed after birth was determined as well as 
the creatinine excretion. As creatinine excretion is correlated with body size and muscle mass, the total hydroxyproline (mol/1) $/$ creatinine (mmol/1) or THP/Cr. ratio was used instead of the absolute values of the total hydroxyproline excretion as it gives more consistent results for subjects of the same blological age. single samples of urine could be used because these show a good correlation with 24-hour collections of urine. 5o selected term infants whose nutritional status ranged from severe disproportional growth retardation to normal were investigated. No correlation between the degree of intrauterine malnutrition and the THP/Cr. ratio could be established, indicating that urinary hydroxyproline excretion cannot be used clinically as a measure of intraterine malnutrition of the newborn, probably because near term intraterine growth is retarded already under normal conditions. The nomal range of urinary hydroxyproline excretion being already wide, intrauterine malnutrition does not add a measurable and significant decrease to the hydroxyproline excretion. As the first urine of newborns closely resembles ammiotic fluid, the determination of hydroxyproline levels in amniotio fluid to quantify intrauterine malnutrition prenatally will probably not be very useful in clinical practice.

In 2.2 and publication II the incidence of 6 common neontal complications (asphyxia, acidosis, hypothermia, hyperviocosity. hypoglycemia, and hyperbilirubinemia) was analyed in a group of 500 term infants subdivided by their distribution on the percentile blocks of birthweight for gestational age and of the ponderal index. The results showed that a small ponderal index predicts more accurately the accurrence of neonatal complications (except hyperbilinubinemia) than a low birthweight for gestational age (defined as weight below the loth percentile). In the group of small-for-gestational age infants especially those infants showing disproportional growth retardation at birth 
(aiagnosed by a small ponderal index) suffer from neonatal complications. The latter feature was further investigated in a group of term very mall-for-gestational age infants (birthweight below the 2.3 percentile for gestational age) in publication III. Again the disproportionally grown infants showed more neonatal complications than the more proportionally grown infants. From papers II and III the conclusion can be drawn that a small ponderal index (especially below the 10th percentile) selects those term (small-for-gestational age) infants at high risk of neonatal complications.

In 2.3 and publications $I V$ and $V$ the physical growth in early chillhood of a group of 25 normal term A.G.A. infants is compared with a group of 25 term S.G.A. Infants presenting clinical signs of intrauterine malnutrition and a small ponderal index at birth. Both groups were free from other perinatal morbidity and chronic diseases and were carefully matched for age, sex, bixth rank and social class. Weight, length, head circumference, skinfold, and skeletal maturity have been studied as parameters of postnatal. growth. Despite the presence of catch-up growth during the first 6 months after birth the infants malnourished in utero were still underweight-for-liength with lower mean skinfold measures and a gradier mean head circumference at the age of 3 years in comparison with the matched controls. Though at birth the infants malnourlshed in utero had a significant retardation in skeletal maturity, at 3 years of age their average skeletal maturity approached that of the controls. However, those deprived infants with a length below the national loth percentile at the age of 3 years still showed a retarded skeletal growth in comparison with those who had reached a length above the loth percentile. So it can be said that infants presenting signs of intrauterine malnutrition at birth grow less well than normal controls (despite a period of catch-up growth) and behave in this respect like S.G.A. 
infants in general. This may be due to the presence of many disproportionally grown infants in the groups of S.G.A. Infants studied by other authors.

Section 2.4 and publications VI and VII describe the behaviour, the neurological development, and the language development of the same infants described in section 2.3 and publications IV and $V$ at the age of 3 years. Behaviour was studied using the behaviour screening questionnaire (B.S.Q.) of Richman and Graham and a behaviour observation report (B.O.R.). The incidence of problematic behaviour among the infants malnourished in utero was high: hyperactivity and concentration disorders on one side and exaggerated fears on the other side were two characteristic patterns of behaviour. Neurological dysfunction and language delay occurred in about one third of the intrauterine malmourished infants. Language delay was often seen in growth reduced infants with significant behaviour problems, a problem well. known to speech therapists. Neurological dysfunction and language delay as well as neurological dysfunction and behaviour problems turned out to be interrelated also. The results demonstrate that intrauterine malnutrition often results in signs of brain dysfunction at the age of 3 years and that behaviour problems, neurological dysfunction, and language delay are comparable as indlcator for brain dysfunction at the age of 3 years. Early diagnosis of brain dysfunction by means of the described methods should be gtressed in these infants.

Finally it is obvious that infants malnourished in utero (disproportionate growth retardation, subacute fetal distress) are at high risk of neonatal complications (Iike asphyxia, acidosis, hypoglycemia, hyperviscosity, and hypothermia), disturbed physical growth and brain aysfunction in early childhood. The calculation of the ponderal index at birth deserves a place beside the estimation of birthweight for gestational age as a 
means to recognize these infants: a small value (e.g. below the 10th percentile for getational age) should irrespective of the birthwelght of the newborn be interpreted as a reason to considar the infant at an increased riak of neonatal and early childhood notbialty. 
In de jaren zestig wer in toenemende mate duidelijk dat niet alle pasgeborenen met een laag geboortegewicht (waarvoor veelal een grens van 2500 gram wordt gehanteerd) te vroeg (prematuur) geboren waren. Ongeveer één derde van alle pasgeborenen met en laag geboortegewicht bleek veel te licht van gewicht voor de opgegeven zwangerschapsauur (sma11-for-gestational age) en tijdens de zwangerschap (intrauterien) onvoldoende gegroeld te zin. Een aanziendijk percentage van de kinderen met een laag geboortegewicht die in de jaren vijftig en het begin van de jaren zestig geboren waren. bleek later meer of minder gehandicapt te zijn. Meer recente onderzoeken hebben laten zien dat een verbeterde perinatale zorg voor de wwangere moeder en har pasgeboren kind leidt tot een betere prognose van kinderen met een laag geboortegewicht. Het ontbreken in bovenvermelde studies van een onderverdeling in prematuren en in pasgeborenen die intrauteriene groeivertraging doomakten, heeft ertoe geleid dat deze onderzoeken geen goed antwoord kunnen geven op de vraag hoe de prognose van een kind met intrateriene groeivertraging ingeschat moet worden en dit wordt actueel door de sterk toegenomen mogelijkheden van de perinatale medische zorg in het latgte decennium. Verder id ondertugsen dulidelijk geworden dat pasgeborenen met een laag geboortegewicht voor de zwangerschapsduur zeker geen homogene groep vormen.

Intrateriene groeivertraging wordt in het algemeen gedefinieerd als een geboortegewicht beneden de $3 e$, 5e of 10 e percentiel voor de zwangerschapsduur. Echtex, an de hand van deze definitie wordt een groep pasgeborenen geselecteerd warwan de groeivertraging op verschillende grondslagen kan berusten. Bij de indeling naar de etiologie van de intrauteriene groeivertraging onderscheidt men "ongunstige" factoren welke hun oorsprong winden 
In de foetus en/of de placenta (zoals chromosomale aandoeningen) en 'ongunstige" exogene factoren welke inwerken op de foetus on/of de placenta lzoals intrauteriene infecties en hypertensie /toxlcoge). Bif klinisch onderzoek kunnen pasgeborenen die intrauteriene groeivertraging doomakten, worden onderschelden in kinderen met en zonder duidelijke aangeboren ziekten (zoals chromosomale aandoeningen, aangeboren afwijkingen en infecties). De dagelijkse praktijk leert echter dat de genoemde factoren slechts in een klein percentage van de pasgeborenen met intrauteriene groeivertraging een rol spelen, veelal is er geen directe oorzak an te wijzen voor de groejvertraging in utero.

In gevallen van intratuteriene groeivertraging zonder dat er sprake is van een foetale ziekte of een genetisch klein kind kan men een onderverdeling aabrengen aan de hand van de dur van groeivertraging. Als de groeivertraging vroeg in het derde trimester begint (en mandenlang durt), zullen alle lichaamsmaten (gewicht, lengte en schedelomtrek) evenredig (geproportioneerd) klein zijn. Gruenwald spreekt in deze gevallen van chronische foetale distress, hetgeen hetzelfde is als geproportioneerde Intrauteriene groeivertraging. Begint de groeivertraging pas in de laatste weken van de zwangerschap, dan zal het gewicht opvallend verlaagd zijn terwijl de lengte en de schedelomtrek nagenoeg normaal zijn. De pasgeborene zal er sterk 'vermagerd" (gedisproportioneerd) witzien en de gewicht/lengte verhouding zal kleiner uitvallen. In deze gevallen wordt gesproken van subacute foetale distres (wolgens Gruenwald) of beter: gedisproportioneerde intrauteriene groelvertraging. Gedisproportioneerde en geproportioneerde intrauteriene groeivertraging kunnen objectief worden onderscheiden door de mate van disproportlonele groei te kwantificeren met behulp van een gewicht/lengte ratio zoals de ponderal index (100 $\mathrm{x}$ gewicht in grammen/lengte in centimeters tot de derde macht). In deze dissertatie werd steeds van genoemde ponde- 
ral index gebruik gemakt om bij de geboorte de voedingstoestand van de à terme pasquborene te bepalen.

Sectie 2.1 en publicatie I behandelen de mogelijkheid om de uitscheiding van hydroxyproline in de urine te gebruiken als biochemische matstaf voor de diagnostiek van intrauterine groeivertraging bij de pasgeborene. Voor deze mogelijkheld pleiten de observaties dat de uitscheiding van hydroxyproline in de urine goed correleert met de groeisnelheid van zuigelingen en jonge kinderen, dat hydroxyproline een betrouwbare index is van het collageenmetabolisme in het skellet en dat de skeletrijping vertraagd is bij gedisproportioneerde groeivertraging en goed correleert met de ponderal index. Bij dit onderzoek werd de ernst van de intrauteriene groeivertraging gekwantificeerd door middel van de deviatie van de ponderal index ten opzichte van de 50e percentiel. Door middel van chemische analyse werd de totale hydroxyproline en de creatinine uitscheiding bepald in het eerste urinemonster dat na de geboorte werd geloosd. Ondat de creatinine uitscheiding correleert met de lichamsgrootte en de spiermassa, werd de totale hydroxyproline (mmol/1) / creatinine (mmol/1) of THP/Cr. ratio gebruikt in plats van de absolute waarden van de totale hydroxyproline uitscheiding. Deze ratio levert meer consistente resultaten op woor personen van eenzelfae biologische leeftijd. Kleine monsters urine konden worden gebruikt ondat deze goed correleren met volledige 24 uurs urine porties. 50 Geselecteerde a terme pasgeborenen werden onderzocht, hun voedingstoestand varieerde van sterk gedisproportioneerde groelvertraging tot normal. Er kon geen relatie worden vastgesteld tussen de ernst van de groeivertraging en de THP/Cr. ratio. Dit houdt in dat de urine uitscheiding van hydroxyproline voor de kliniek geen bruikbare mat kan vormen om de ernst en/of duur van de doorgemakte intrauteriene groeivertraging vast te stellen. Dit is warschijnlijk het gevolg van het feit dat de intrauteriene groei. 
nomallet al afneemt bij het bereiken van de a terme datum. Aangezien de normale variatie in de hydroxyproline uitscheiding in de urine al groot is, verlaagt intrauteriene groeivertraging de ultacheiding ervan onvoldoende om meetbare verschilien op te Leveren. De eerse urine van pasgeborenen lijkt sterk op vruchtwater en gezien het bovenstande zal het dan ook weinig wardevol zijn om het hydroxyproline-gehalte te bepalen in het vruchtwater als antenatale mat voor groelvertraging.

In sectie 2.2 publicaties II en III worden twee problemen belicht. In publicatie II werd de incidentie van 6 veel voorkomende neonatale complicatieg (asphyxie, acidose, hypothermie, hyperviscositeit, hypoglycemie en hyperbilirubinemie) onderzocht in een groep van 500 à terme pasgeborenen. De onderzoeksgroep werd onderverdeeld naar de plats van het geboortegewicht (voor de zwangerschapsduur) en de ponderal index op de percentielcurven. De resultaten lieten zien dat een kleine ponderal index een grotere voorspellende waarde heeft ten aanzien van het optreden van neonatale complicaties (met ulltzondering van hyperbilirubinemie) dan een ondergewicht voor de zwangerschapsduur (gedefinieerd als een geboortegewicht beneden de $10 e$ percentiel). Binnen de groep van pasgeborenen met een te laag geboortegewicht voor de zwangerschapsduur toonden vooral diegenen die gedisproportioneerde groejvertraging in utero doormakten (vastgesteld aan de hand van een kleine ponderal index) neonatale complicaties. Dit latste verschijnsel werd nader onderzocht in publicathe III in een groep van à terme pasgeborenen met een nog lager geboortegewicht voor de zwangerschapsduur (beneden de 2.3 percentiell. Wederom toonden de gedisproportioneerde pasgeborenen meer neonatale problemen dan de geproportioneerde pasgeborenen. Vit beide studies kan de conclusie worden getrokken dat een kleine ponderal index vooral die à terme pasgeborenen (met een laag geboortegewicht voor de zwangerschapsduur) selecteert die een 
hoog risico lopen om neoratale complicaties te ondervinden.

In sectie 2.3 en publicaties IV en $v$ wordt de lichamelijke groei in de eerste levensjaren van een groep van 25 normale à terme pasgeborenen vergeleken met een graep van 25 à terme pasgeborenen met $k i$ inische tekenen van gedisproportioneerde intrauteriene groeivertraging, vastgesteld an de hand van een kleime ponderal index bij de geboorte. Beide groepen kinderen toonden geen opvallende klinische problemen in de neonatale periode behoudens de aanwezigheid van groeivertraging, tevens waren de groepen goed vergelijkbaar qua leeftijd, geslacht, rangorde in het gezin en sociale klasse. Bij deze studie werden het gewicht, de lengte, de schedelomtrek, de huidplooidikte en de uitrijping van het skelet als parameters bestudeerd. Hoewel de gedisproporm tioneerde groep kinderen in de eerste 6 levensmaanden een duidelijke inhalgroei liet zien, hadden deze kinderen op 3 jarige leeftija nog steeds een duidelijke achterstand in gewicht (raar lengte), een verminderde huidplooidikte en een kleinere schedelomtrek in vergelijking met de controle groep. Hoewel de gedisproportioneerde pasgeborenen bij de geboorte een duidelijke vertraging in de uitrijping van het skelet hadden, bemaderde op 3 jarige leeftijd hun gemiddelde skeletrijping nagenoeg die van de controle groep. Echter, de kinderen uit de onderzoeksgroep wier lengte bij 3 jaar nog onder de loe percentieliljn lag, hadden een vertraagde skeletrijping ten opzichte van hen die een lengte boven de loe percentiellijn hadden bereikt. Uit deze onderzoeken kon worden geconcludeerd dat pasgeborenen met gedisproportionearde intrauteriene groelvertraging minder goed groelen dan normale pasgeborenen ondanks het felt dat er in de eerste 6 levensmaanden inhalgroei optreedt. Zij gedragen zich in dit opzicht als de hele groep van kinderen met een laag geboorteglwicht woor de zwangerschapsduur. Dit is warschijnlijk te verklaren uit de aanwezigheid van veel kinderen met gedisproportioneerde groelver- 
traging binnen de groepen pasgeborenen met een laag geboortegewht wor de zwangerschapsduur welke door andere onderzoekers werden ragezien.

In 2.4 en publicaties VII en VII wordt het gedrag, het neurologisch functioneren en de taalontwikkeling van de in publicaties IV en beschreven onderzoeksgraep geanalyseerd op de leeftijd van 3 jaar. Het gedrag werd bestudeerd met behulp van de vragenlijet van Richman en Graham (B.S.Q.) en door middel van een gestandadrabeerde gedragsobservatie (B.O.R.). Gedragsproblemen kwamen in grote getale voor bij de groep met intrauteriene groeivertraging. Er werden hierbij 2 karakteristieke gedragspatronen waargenomen: waar de ene groep kinderen hyperactiwiteit en concentratiestoornissen aan de dag legde, toonde de andere groep kinderen vaak een opvallend angstig gedrag. Neurologisch dysfunctioneren en een vertraagde talontwikkeling werden in ongeveer éénderde van de kinderen met intrauteriene groeivertraging vastgesteld. Een vertragde taalontwikkeling ging veelal samen met opvallende gedragsproblemen, een door logopedisten veel gezien probleem. Dok neurologisch dysfunctioneren correleerde goed met een vertraagde taalontwikkeling en met het bestaan van gedragsproblemen. Het geheel wijst erop dat intrauteriene groeivertraging vak ultmondt in de anwezigheld van tekenen van cerebraal dysfunctioneren bij na-onderzoek op 3 jarige leeftija en dat op die leeftijd gedragsproblemen, neurologisch dysfunctioneren en een vertraagde talontwikkeling onderling vergelijkbaar zijn als indicatoren voor het bestaan van cerebrale dysfunctie. Het zal duldelifk zijn dat het wroegtijalg vaststellen van het bestaan van cerebraal dysfunctioneren bij het kind met intrauteriene groelvertraging door middel van de beschreven technieken van veel belang is.

In het kort kan aan de hand van de verrichte onderzoeken gezegd worden dat pasgeborenen met gedisproportioneerde intra- 
uteriene groeivertraging een hoog risilco lopen om neonatale complicaties te krijgen (zoals asphyxie, aclaose, hypoglycemie. hyperviscositeit en hypothermie), minder goed te groelen na de geboorte en on cerebraal suboptimal te functioneren op 3 jarige leeftijd. Het is aambevelenswaardig bij de geboorte niet alleen het gewicht te relateren an de zwangerschapsduur, maar ook de ponderal index te berekenen: een kleine waarde (b.v. beneden de loe percentiel voor de zwangerschapsduur) moet onafhankelijk van het geboortegewicht van de pasgeborene als een reden worden beschouwd om het kind in te delen bij de groep van pasgeborenen met een verhoogd risico. 


\section{References for chapter I and II}

Alford CA (1971): Immunoglobulin determinations in the diagnosis of fetal infection. Pediatr. Cin. Worth Am. 18: 99-113.

Alford $C A$, Schaefer J., Blankenship WJ, Straumfjord JV, Cassady G (1967): A correlative immunologic, microbiologic and clinical approach to the diagnosis of acute and chronic infections in newborn infants. New Engl. J. Med. 277: 437-449.

Allison DJ, Walkex A, Smith QT (1966): Urinary hydroxyproline: creatinine ratio of normal humans at various ages. Clin. Chim. Acta 14: $729-734$.

Amiel-Tison C (1968): Neurological evaluation of the maturity of newborn infants. Arch. Dis. Child 43:89-93.

Babson SG, Kangas J (1969): Preschool. intelligence of undersized term infants. Am. J. Dis. Child 117: 553-557.

Babson SG (1970): Growth of low birthwelght infants. J. Pediatr. $77: 11-18$.

Babson SG, Behrman RE, LessI R (1970): Fetal growth-Liveborn birth weights for gestational age of white midale class infants. Pediatrics $45: 937-944$.

Bacsik RD (1.977): Meconfum aspiration syndrome. Pediatr. Clin. North Am. 24:463-479.

Baker I, Cantwe11. DP, Mattison RE (1980): Behaviour problems in children with pure speech disorders and in children with combined speech and language disorders. is. Abnorm. Child Paychol. 8: 245-256.

Barr GD, Allen CM, Shinefield HR (1972): Height and weight of 7.500 chilaren of three skin colors. Pediatric multiphasic program: Report no. 3. Am. J. Dis. Child. 124: 866-872.

Battaglia FC, Lubchenco LO (1967): A practical classification of newborn infants by weight and gestational age. J. Pediatr. 71 : $159-163$. 
Beargie RA, James VL, Greene JW (1970): Growth and development of sma11-for-date newborns. Pediatr. Clin. North Am. 17: 159-167. Behrman RE (1979): High-risk infant. In: Nelson Textbook of Pediatrics. Eds. VC Vaughan, RJ MoKay, and RE Behrman, 11th Edition. Saunders, Philadelphia, pp. 398-415.

Bensusan HB, Klein L (1965): Catabolism of collagen. Science 148: $1758-1759$.

Berg BJ Van Den, Yerushalmy J (1966): The relationship of the rate of intrauterine growth of infants of low birthweight to mortality, morbidity and congenital anomalies. J. Pediatr. 69: $531-545$.

Bergqvist $G(1974)$ : Viscosity of the blood in the newborn infant. Acta Paediatr. Scand. 63: 858-864.

Brent JL, Jensch RP (1967): Intrauterine growth retardation. Adv. Teratology $2: 139-227$

Birkenhäger JC (1970): The urinary excretion of hydroxyproline in metabolic aisorders of connective tissue and bone. Folia Med. Neer1. 13: 79-87.

Bissenden JG, Scott P, Wharton BA (1978): Assessment of nutrition status of the fetus by examination of amniotic fluid. Arch. Dis. Child. 53: 263 .

Bissenden JG, Scott P. Milner S, Doughty S, Ratnapala L, Wharton BA (1979): The biochemistry of amniotic fludd with poor fetal growth. Brit. J. Obstet. Gynaecol. 86: 540-547.

Bosley ARJ, sibert JR, Newcombe RG (1981): Effects of maternall smoking on fetal growth and nutrition. Arch. Dis. Child. 56: $727-729$.

Brandt I (1981): Brain growth, fetal malnutrition, and clintical consequences. J. Perinat. Med. 9: 3-26.

Brown BL, Gleicher N (1981): Intrauterine meconium aspiration* Obstet. Gynecol. 57:26-29.

Butler NR, Bonham DG (1963): Perinatal mortality survey, Living- 
stone, Edinburgh.

Cabacungan $\mathbb{N B}$, Miles CW, Abernathy RP, Ritchey SJ (1973): Hydroxyproline excretion and nutritional status of children. Am. J. Clin. Hutr. 26: 173-176.

Campbeli s (1969): The prediction of fetal maturity by ultrasonic measurement of the blparietal diameter. Br. J. Obstet. Gynae$\operatorname{col} \cdot 76: 603-609$.

Campbe11 S (1974): The assessment of fetal development by diagnostic ultrasound. Clin. Perinatol. 1: 507-525.

Chamberlain $R$, Davey $A(1975)$ : Physical growth in twins, postmature and small-for-dates children. Arch. Dis. Child. 50: 437442 .

Chamberlain RN, Simpson RN (1977): Cross-sectional studies of physical growth in twins, postmature and small-for-dates children. Acta Paediatr. Scand. 66: 457-463.

Chandra RK, Matsumura T (1979): Ontogenetic development of the immune system and effects of fetal growth retardation. I. Perinat. Med. 7: 279-290.

Chandraschkharan N. Candilsh JK (1973): The urinary 'hydroxyproline index" in hospütalised and normal Malaysian children. Trop. Geogr. Med. 25: 71-74.

Chase HP, Dantere CS, Welch NN, O'Brlen D (1971): Intrauterine undernutrition and brain development. Pediatrics 47: 491-500.

Coid CR (1973): Comparative aspects of infection during pregnancy. In: Intrauterine infections. Eds. $K$ Elliott and J Knight. Ciba Edn. Symp. 10. Elsevier, Amsterdam, pp. 117-130. Colman HI, Rienzo J (1962): The small term baby. Obstet. Gynecol. $19: 87-91$.

Commey JoO, Fitzhardinge PM (1979): Handicap in the preterm smal1-for-gestational age infants. J. Pediatr. 94: 779-786.

Cooke RWI, Lucas A, Yudkin PLN, Pryse-Davies $J$ (1977): Head circumference as an index of brain weight in the fetus and 
newborn. Early Hum. Dev. 1: 145-149.

Cruise MO (1973): A longltudinal study of the growth of low birthweight infants. I Velocity and distance growth, birth to

3 years. Pediatrics $51: 620-628$.

Davies DP, Platts P, Pritchard JM, Wilkinson PW (1979): Nutritional status of light-for-date infants at birth and its influence on early postnatal growth. Arch. Dis. Child. 54:703-706. Davies DP, Beverly D (1979): Changes in body proportions over the first year of lifie: comparisons between "light-for-dates' and "appropriate-for-dates" term infants. Early Hum. Dev. 3: $263-265$.

Davies $D P$ (1980): size at birth and growth in the first year of life of babies who are overweight and underweight at birth. Proc. Nutr. Soc. 39: 25-33.

Davies DP (1981): Growth of "small-for-dates' babies. Early Hum.

Dev. 5: $95-105$.

Davies PA, Robinson RJ, Scopes JW, Tizard JPM, Wigglesworth IS (1972): Medical care of newborn babies. Clinics in Developmental Medicine nos. 44/45. Spastics International Medical Publications. Heinemann, London.

Dawes GS (1974): Breathing before birth in animals and man. N. Eng l. J. Med. 290: 557-559.

Dobbing J, Sands J (1970): Timing of neuroblast multiplication in developing human brain. Nature $226: 639-640$.

Dobbing J. Sands J (1973): Quantitative growth and development of human brain. Arch. Dis. Child. 48: 757-767.

Dobbing J. Sands I (1979): Comparative aspects of the brain growth spurt. Early Hum. Dev. 3: 79-83.

Dobbing $J$, Sands $J$ (1981): Vulnerability of developing brain not explained by cell number/cell size hypothesis. Early Hum. Dev. $5: 227-231$.

Doorn Iu (1967): Groei en geslachtelijke rijpllng bij cerebraal 
defecte kinderen: Thesis, Leiden.

Dri11:en CM (1970): The smal-for-date infant: Etiology and prognosis. Pediatr. Clin. North Am. 17:9-24.

Dubowtiz LMS, Dubowitz $v$, Golaberg C (1970): Clinical assessment of gestational age in the newborn infant. $J$. Pedilatr. $77:$ $1-10$.

Dubowitz $V(1974)$ : The infant of inappropriate size. In: Size at birth. Eds. K Elliott and $J$ Knight. Ciba Fan. Symp. 27, Elseviex, Ansterdam, pp. 47-64.

Dunn PM (1981): Variations in fetal growth: Some causes and effects. In: Fetal growth retardation. Eds. FA van Assche and WB Robertson. Churchill Livingstone, Edinburgh, pp. 79-89.

Edwards $S$, Hartog $M$, Pennock $C_{A}$, Apley $J$ (1976): Relation of urinary total hydroxyproline: creatinine ratio to height relocity in children with retarded growth. Arch. Dis. Child. $51: 149-152$.

Elst $C W$ van der, Molteno CD, Malan AF, Heese $H$ de $V(1980)$ : The management of polycythaemia in the newborn infant. Early Hum. Dev. $4: 393-403$.

Fancourt R, Campbell S, Harvey D, Norma AP (1976): Follow-up study of small-for-dates infants. Br. Med. J. 1: 1435-1437.

Farr V, Mitchell RG, Neligan GA, Parkin JM (1966): The definition of some external characteristics used in the assessment of gestational age of the newborn infant. Dev. Med. Child Neurol. 8: $507-511$.

Ferguion AC (1978): Prolonged impaiment of cellular immunity in children with intrauterine growth retardation. J. Pediatr. 93: $52-56$

Finne PH (1966): Erythropoletin levels in cord blood as an indicator of intrauterine hypoxia. Acta Padiatr. Scand. 55: $478-489$.

Finnström 0 (1971): studies on maturity in newborn infants. IV 
Postnatal radiological examination of epiphyseal centers. Neuropaediatrie $3: 119-128$.

Fitzhardinge PM, steven EM (1972 a): The small-for-date infant. I

Later growth patterns. Pediatrics $49: 671-681$.

Fitzhardinge PM, steven EM (1972 b): The small-for-date infant.

II Neurological and intellectual sequelae. Pediatrics 50 : $50-57$.

Fox H (1976): The histopathology of placental insufficiency. J. Clin. Pathol. 29, Supp. (Roy. Coll. Path.) 10: 1-8.

Fox H (1981): Placental malformation as a factor in intraterine growth retardation. In: Fetal growth retardation. Eds. FA van Assche and WB Robertson. Churchill Livingstone, Edinburgh, pp. $117-125$

Fujikura $J$, Klionsky B (1975): The significance of meconium staining. Am. J. Obstet. Gynecol. 121:45-50.

Fujimura M, Seryu JI (1977): Velocity of head growth during the perinatal period. Arch. Dis. Child. 52: 105-112.

Futrel1 MF, Windham F, Kilgore LT (1975): Hydroxyproline index: an indicator of nutritional status. J. Am. Diet. Assoc. 67: $125-128$.

Graf U, Vest M (1971): Zur normalen Hydroxyprolinausscheidung im Urin bei Sảuglingen, Kindern and Adoleszenten. $Z$, Kinderheilk. 110: $128-139$.

Gross GP, Hathaway WE, McGaughey HR (1973): Hyperviscosity $\mathbb{L}^{\mathrm{in}}$ the neonate. J. Pediatr. 82: 1004-1012.

Gruenwald P (1963): Chronic fetal distress and placental insufficiency. Biol. Neonate 5:215-265.

Gruenwald P (1964 a): The fetus in prolonged pregnancy. Am. J. Obstet. Gymecol. 89: 503-509.

Gruenwald $\mathrm{P}(1964$ b): Infants of low birthweight among 5,000 deliveries. Pediatrics 34: 157-162.

Gruenwald P (1966): Growth of the human fetus. I Normal growth 
and its variation. Am. J. Obstet. Gynecol. 94: 1112-1119.

Gruenwald P (1974): Pathology of the deprived fetus and its supply line. In: size at birth. Eas. K Elliott and J Knight. cibe Fdn. Symp. 27, Elsevier, Amsterdam, pp. 3-26.

Haldex SA (1972): Serum IgM in diagnosis of infection in the newborn. Arch. Dis. Child 47: 382-393.

Hakanson $D O$, on $W(1980)$ : Hyperviscosity in the sma11-for-gestational age infant. Biol. Meonate $37: 109-112$.

Hanshaw JB, Schultz FW, Melish MM, Dudgeon JA (1973): Congenital cytomegalovirus infection. In: Intrauterine infections. Eds. $\mathrm{K}$ Elliott and J Knight. Clba Fan. Symp. 10, Elsevier, Amsterdam, pp. $23-43$.

Haworth JC, Ellestad-Sayed JJ, King J, Dilling LA (1980 a): Fetal growth retardation in cigarette-smoking mothers is not due to decreased maternal food intake. Am. J. Obstet. Gymecol. 137: $719-723 *$

Haworth JC, Ellestad-Sayed JJ, King J, Dilling LA (1980 b): Relation of maternal cigarette-smoking, obesity, and energy consumption to infant size. Am. J. Obstet. Gynecol. 138: $1185-1189$.

Haymond MW, Karl IE, Fagliara As (1974): Increased gluconeogenic abstrates in the small-for-gestational age infant. N. Engl. J. Med. $291: 322-328$.

Hi1l DE (1974): Experimental growth retardation in rhesus monKeys. In: Size at birth. Eds. K Elliott and J Knight. Ciba Fan. Symp. 27, Elsevier, Amsterdam, pp. 99-113.

Houston IB, Zeiss PM (1976): Intrauterine renal function and the amniotic fluid. J. Physiol. 257: 20-21 P.

Howard FM, Hill JM (1979): Drugs in pregnancy. Obstet. Gynecol. Surv. $34: 643-653$.

Howells GR, Wharton BA, McCance RA (1967): Value of hydroxyproline indices in malnutrition. The Lancet 1: 1082-1083. 
Hughes WT (1970): Infections and intrauterine growth retardation.

Pediatr. Clin. North Am. 17: 119-124.

Huisjes HJ (1981): Intrauterine growth retardation. A question of definition. In: Aspects of perinatal morbidity. Ed. HJ Husjes. Universitaire Boekhandel Nederland $B V$, Groningen, pp. $54-59$.

Jårai I, Mestyấn J, Schultz K, Lắzár A, Halász M, Krassy I (1977): Body size and neonatal hypoglycaemia in intrauterine growth retardation. Early Hum. Dev. 1: 25-38.

Jasin HE, Smiley JD, ziff $M(1962$ a): Influence of growth on total hydroxyproline. J. Clin. Invest. 41: 1368.

Jasin HE, Fink CW, Wise W, Ziff M (1962 b): Relationship between urinary hydroxyproline and growth. J. Clin. Invest. 41: 19281935 .

Jurgens-var der Zee AD, Bierman-van Eendenburg MEC, Fidler VJ, Olinga AA, Visch JH, Touwen BCL, Huisjes HJ (1979): Preterm birth. growth retardation and acidemia in relation to neurological abnormality of the newborn. Early Hum. Dev. 3: 141-154. Keirse MJNC (1981): Aetiology of intrauterine growth retardation.

In: Fetal growth retardation. Eds. FA van Assche and WB

Robertson. Churchill Livingstone, Edinburgh, pp. 37-56.

Kivirikko KI (1973): Urinary excretion of hydroxyproline in health and disease. Int. Rev. Connect. Tissue Res. 5: 93-163. Klein L, Teree TM (1966): Skeletal metabolism in early infancy: urinary hydroxyproline. J. Pediatr, 69: 266-273.

Kloos K, Vogel M (1974): Pathologie der Perinatal Periode. Thieme, stuttgart.

Kloosterman GJ (1970): On intrauterine growth. The aigniflcance of prenatal care. Int. J. Gynecol. Obstet. 8: 895-912.

KIujber L, Mestyán J, sulyok E, Soltész G (1972): Urinary hyaroxyproline excretion in normally grown and growth-retarded newborn infants. Biol. Neonate 20: 196-213. 
Kol lee LAA, Momnens LAH, TK1Jbels JWF, Veerkamp JH, Janssen AJW, Hara-Husting $\mathrm{H}$ wan (1979): Gluconeogenic key enzymes in normal and Intraterine growth-retarded newborn rats. Early Hum. Dev. 3: $345-352$.

Kollée LAA (1980): Neonatal hypoglycemia hn intrauterine growthretarded rats. Thesis, Wijmegen.

Kontras SB (1972): Polycythemia and hyperviscosity syndromes in infants and children. Peditr. Cin. Worth Am. 19:919-933.

Lafeber HN (1981): Experimental intramterine growth retardation in the guinea pig. Thesis, Rotterdam.

Lattinen o (1975): Clinical applications of urinary hyaroxyproline determination. Acta Med. Scand., Supp1. 577: 1-57.

de Lange EE (1979): De invloed van heroine en methadon op de zwangerschap en de pasgeborene. Neal. Tijdschr. Geneeskd. 123: $1154-1159$

de Leeuw $R$ (1972): Hypoglykemie bij dysmature pasgeborenen. Thesis, Amsterdam.

de Leeuw R (1973): Dysmaturiteit. Ned. Tijdschr. Geneeskd. 117: $1315-1321$.

de Leeuw $R$, de Vxies IJ (1976): Hypoglycaemie in small-for-dates newborn infants. Pediatrics $58: 18-22$.

Lin CC, Moawed AH, Rosenow PJ, River P (1980): Acia-base characteristos of fetuses with intrauterine growth retardation auring labor and delivery. Am. J. Obstet. Gynecol. 137: 553559.

Lind $\mathrm{T}$, Kendel1 A, Hytten FE (1972) : The role of the fetus in the formation of amniotic Eludd. BI. J. Obstet. Gynaecol. 79 : $289-298$

Long PA, Abell DA, Eeischer NA (1980): Eetal growth retardation and preeclampsia. Br. J. obstet. Gynaecol. 87: 13-18.

Low JA, Galbraith RS, Muir D, Killen H, Karchmar J, Campbel1 D (1978): Intrauterine growth retardation: A preliminary report 
of long-term morbidity. Am. J. Obstet. Gynecol. 130: 534-545.

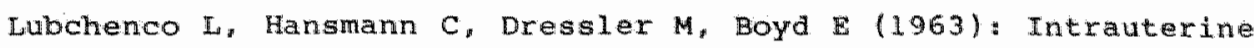
growth as estimated from liveborn birth weight data at 24 to 42 weeks of gestation. Pediatrics 32 : 793-800.

Lubchenco LO, Hansmann $C$, Boyd $E$ (1966): Intrauterine growth in length and head circumference as estimated from live births at gestational ages from 26 till 42 weeks. Pediatrics $37: 403-$ 408 .

Lubchenco LO, Bard $\mathrm{H}$ (1971): Incidence of hypoglycemia in newborn infants classified by birthweight and gestational age. Pediatrics 47: 831-838.

Lubchenco LO, Searls DT, Brazie JV (1972): Neonatal mortality rate: Relationship to birth weight and gestational age. J. Pediatr. 81: 814-822.

Lubchenco LO (1976): Congenital Malformations. In: The high risk infant. Saunders, Philadelphia, pp. 213-232.

Lubchenco Lo (1981): Assessment of weight and gestational age. In: Neonatology, pathophysiology and management of the newborn. Ed. GB Avery. 2nd Edition. Lippincott, Philadelphia, pp. $205-224$

Lugo G, Cassady G (1971): Intrauterine growth retardation. Clinicopathologic findings in 233 consecutive infants. Am* J. Obstet. Gynecol. 109: 615-622.

MacDonald HM, Mulligan JC, Allen AC, Taylor PM (1980): Neonatal. asphyxia. I Relationship of obstetric and neonatal complications to neonatal mortality in 38.405 consecutive deliveries. J. Pediatr. 96: 898-902.

Marsiall WA (1971): Evaluation of growth rate in height over periods of less than one year. Arch. Dis. Child. 46:414-420 Martell M, Falkner F, Bertolini LB, Diaz JL, Nieto F, Tenzex SM, Belitzky R (1978): Early postnatal growth evaluation in full term, preterm and small-for-dates infants. Early Hum. Dev. 1: 
$313-323$

Matthews TG, $0^{*}$ Herlihy $C(1978)$ : Stgnificance of raised immunoglobulin M levels in cord blood of small-for-gestational age Infants. Arch. Dis. Child. 53:895-898.

Mattison RE, Cantwell DP, Baker I (1980): Dimensions of behaviour in children with speech and language disorders. J. Abnorm. Child Psychol. 8: $323-338$.

Mentzer WC (1978): Polycythaemia and the hyperviscosity syndrome in newborn infants. Clin. Haematol. 7: 63-74.

Miller HC, Hassanein K (1971): Diagnosis of impaired fetal growth in newborn infants. Pediatrics $48: 511-522$.

Mi11er HC, Hassanein K (1973): Fetal malnutrition in white new-

born infants: maternal factors. Pediatrics 52:504-512.

Morrow G, Kivirikko KI, Prockop DJ (1966): Hydroxyprolinemia and increased excretion of free hydroxyproline in early infancy. J. Clin. Endocrinol. Metab. 26: 1012-1014.

Morrow G, Kivirikko KI, Prockop DJ (1967): Catabolism and excretion of free hydroxyproline in infancy. J. Clin. Endocrinol. Metab. 27: 1365-1371.

Murphy JF" Drumm JE, Mulcahy L, Daly L (1980): The effect of maternal cligarette smoking on fetal birth weight and on growth of the fetal biparietal diameter. Br. J. Obstet. Gyneecol. 87: $462-466$.

Naeye RL, Blanc W (1965): Pathogenesis of congenital rubella. J.A.M.A. $194: 109-115$.

Naeye RL, Blanc W, Paull C (1973): Effects of maternal nutrition on the human fetus. Pediatrics 52: 494-503.

Naeye RL (1979): The duration of maternal cigarette smoking, fetal and placental disorders. Early Hum. Dev. 3: 229-237.

Neligan GA, Kolvin I, Scott DMcl, Garside RF (1976): Born too soon or born too small. A follow-up study to seven years of age. Clinics in Developmental Medicine no. 61. Spastics Inter- 
national Medical Publications. Heinemann, London.

Neuberger A, Slack HGB (1953): The metabolism of collagen from liver, bone, skin and tendon in the normal rat. Biochem. $J$. $53: 47-52$.

O'Shaughnessy RW: Uterine blood flow and fetal growth. In: Fetal growth retardation. Eds. FA van Assche and WB Robertson. Churchill Livingstone. Edinburgh, pp. 101-116.

Ounsted M, Taylor ME (1971): The postnatal growth of children who were smal-for-dates or large-for-dates at birth. Dev. Med. Child Neurol. 13: 421-434.

Ounsted $M$, ounsted $C$ (1973): On fetal growth rate. Clinics in Developmental Medicine no. 46. Spastics Internatlonal Medical Publications. Heinemann, London.

Ounsted M, Moar $V$, scott WA (198I): Perlnatal morbidity and mortality in small-for-dates babies: the relative importance of some maternal factors. Early Hum. Dev. 5: 367-375.

Papadatos C, Papaevangelou G, Alexiou D, Mendris J (1969): Immunoglobulin levels and gestational age. Biol. Neonate 14: $365-373$.

Papaevangelou G, Papadatos C, Alexiou D (1972): Perinatal mortality and morbidity in 'small-for-dates' newborns. Helv. Paediatr. Acta $27: 415-424$.

Parkinson CE, Wallis $S$, Harvey $D$ (1981): School achievement and behaviour of children who were smal1-for-dates at birth. Dev. Med. Child Neurol. 23: 41-50.

Picou D, Alleyne GAO, Waterlow JC, Sealeins A (1965): Hydroxyproine and creatinine excretion in protein-depleted infants. Biochem. J. 95: $18 \mathrm{P}$.

Polani PE (1974): Chromosomal and other genetic influences on birth weight variation. In: Size at birth. Eds. K Elliott and J Knight. Ciba Fan. Symp. 27, Elsevier, Amsterdam, pp. 127160 . 
Prockop DJ, Kivirikko KI (1967): Relationship of hydroxyproline excretion in urine to collagen metabolism. Ann. Intern. Med. 66:1243-1266.

Prockop DJ, Kivirikko KI, Tuderman L, Guzman NA (1979): The biosynthesis of collagen and 1ts disorders. N. Engl. J. Med. $301: 13-23,77-85$.

Pryse-Davies $J$, Smitham JH, Napier KA (1974): Factors influencing development of secondary ossification centres in the fetus and newborn. Arch. Dis. Child. 49:425-431.

Queenan JT, Kubarych SF, Cook LN, Anderson GD, Griffin LP (1976):

Diagnostic ultrasound for detection of intrauterine growth retardation. Am. J. Obstet. Gynecol, 124:865-873.

Redmond GP (1979): Effects of drugs on intrauterine growth. Clin. Perinatol. $6: 5-19$.

Reisman LE (1970): Chromosome abnormalities and intrauterine growth retardation. Pediatr. Clin. North Am. 17: 101-110.

Renfield ML (1975): The small-for-date infant. In: Neonatology, pathophyslology and management of the newborn. Ed. GB Avery* Lippincott, Philadelphia, pp. 189-201.

Reynell JK (1969): Manual for the Reynell Developemental Language Scales. Experimental edition. M.F.E.R. Publishing Co., Windsor.

Richman N, Graham PJ (1971): A behavioural screening questionnaire for use with three-yearold chlldren. Preliminary findings. I. Child Psychiol. Psychiatry 12:5-33.

Roche AF, Davila GH (1972): Late adolescent growth in stature. Peatatrics 50: $874-880$.

Rohrer F (1921): Der Index der Köperfale als Mass des Ernăhrungszustandes. Münch. Med. Wschr. 68: 580-582.

Roord JJ, Ramaekers LHJ (1978): Quantification of intra-uterine malnutrition. Biol. Neonate 33: $273-277$.

Roord JJ, Ramaekers LHJ, Van Engelshowen JMA (1978): Intrauterine 
malnutrition and skeletal retardation. Biol. Neonate 34 : 167-169.

Salnt-Anne Dargassies $s(1962)$ : The full term newborn; neurological assessment. Biol. Neonate 4: 174-200.

Sands J, Dobbing J, Gratrix CA (1979): Cell number and cell size: a reconsideration of organ growth and development and the control of catch-up growth. The Lancet $2: 503-505$.

Scott $\mathbb{K E}$, Usher $R$ (1964): Epiphyseal development in fetal malnutrition syndrome. N. Engl. J. Med. 270: 822-824.

Scott KE, Usher $R$ (1966): Fetal malnutrition : Its incidence, causes, and effects. Am. J. Obstet. Gynecol. 94: 951-963.

Scott JR (1977): Fetal growth retardation associated with maternal administration of immunosuppressive drugs. Am. J. obstet. Gynecol. 128 : $668-676$.

Sénécal $J$. Grosse $M-C$, Vüncent A, Simon $J$, Lefrèche $J-\mathbb{N}(1977)$ : Maturation osseuse du foetus et du nouveau-né. Arch. Fr. Pediatr. $34: 424-438$.

Sheppard BL, Bonnar J (1980): Ultrastructural abnormalitles of placental villi in placentae from pregnancies complicated by intrauterine fetal growth retardation: their relationship to decidual spiral arterial lesions. Placenta 1 : 145-156.

Sinclair JC (1970): Heat production and thermoregulation in the small-for-date infant. Pediatr. Clin. North Am. 17: 147-167.

Sjöstedt $S$, Engleson G, Rooth G (1958): Dymaturity. Areh. Dia. Child. $33: 123-130$.

Smiley JD, Ziff M (1964): Urinary hydroxyproline and growth. Physiol. Rev. 44: $30-44$.

Smith DW, Truog W, Rogers JE, Greltzer Lu, Skinner AL, McCann JJ, Sedgwick Harvey MA (1976): Shifting linear growth during infancy: Illustration of genetic factors in growth from fetal life through infancy. J. Pediatr. 89: 225-230. 
Smith DW (1977): Growth and 1 ts disorders. Saunders, Philadelphia, pp. 1-17.

Smolders-de Has 1 (1974): Follow-up wat betreft de somatische groei. Maandschr. Kindergenerk. 42:177-185.

soderling B (1953): Pseudoprematurity. Acta Paediatr. Scand. 42: $520-525$

Stein ZA. Susger MW (1976): Prenatal nutrition and mental competence. In: Malnutrition and intellectual development. Ed. JD Lloyd-Stil1. MTP, Lancaster, England, pp. 39-79.

Stetten MR (1949): Some aspects of the metabolism of hydroxyproline, studied with the aid of isotopic nitrogen. J. Biol. Chem. 181: $31-37$.

stevens $\mathrm{K}$, with $\mathrm{FH}(1980)$ : Incidence of neonatal hyperviscosity at sea leve1. J. Pediatr. $97: 118-119$.

Tannex JM, Healy MJR, Lockhart RD, Mackenzle JD, Whitehouse RH (1956): Aberdeen growth study. I The prediction of adult body measurements from measurements taken each year from birth to 5 years. Arch. Dis. Child. 31: 372-381.

Tejani N, Mann LI (1977): Diagnosis and management of the smallfor-gestational-age fetus. Clin. Obstet. Gynaecol. 20: 943955.

Teller WM, Genscher U, Burkharat H, Rommel KC (1973): HydroxyproLine excretion in various forms of growth failure. Arch. Dis. chi1d. $48: 127-132$.

Thalhammer 0 (1964): Pranatale Dystrophie. $z$. Kinderheilkd. 91 : $193-212$.

Thomas YM, Bedi KS, Davies CA, Dobbing $\mathfrak{J}$ (1979): A stereological analysis of the neuronal and synaptic content of the frontal and cerebellar cortex of weanling rats undernourished from birth. Early Hum. Dev. 3: 109-126.

Thomson AM, Billewicz WZ, Hytten FE (1968): The assessment of fetal growth. Br. J. Obstet. Gynaecol. 75: 903-916. 
Touwen BCL (1979): Examination of the child with minor neurological dysfunction. 2nd Edition. Clinics in Developmental Medicine no. 71. Spastics International Medical publications. Heinemann, London.

Treffers PE, de Leeuw R, Huidekoper BL, Gubler F, Leschot NJ,

Verjaal M (1981): Congenital anomalies. A survey of 39,828 infants born during 21 years. In: Aspects of perinatal morbidity. Ed. HJ Huisjes. Universitaire Boekhandel Nederland BV, Groningen, pp. 93-114.

Turner G (1971): Recognition of intrauterine growth retardation by considering comparative birth-weights. The Lancet 2 : $1123-$ 1124.

Tympner KD (1971): Die Bedeutung quantitativer ImmunoglobulinBestimmungen (IgM, IgA) für die Diagnostik und Theraple von Infectionen in der Neugeborenen Periode. Monatschr. Kinderheilkd. $119: 287-291$.

Udenfriend $s$ (1966): Formation of hydroxyproline in collagen. Science $152: 1335-1340$.

Urrusti J, Yoshida P, Velasco L, Frenk S, Rosado A, Sosa A, Morales M, Yoshida $T$, Metcoff $J$ (1972): Human fetal growth retardation: I Clinical features of sample with intrauterine growth retardation. Pediatrics 50: 547-558.

Usher $R$, McLean $F$, Scott KE (1966): Judgment of fetal age. II clnical significance of gestational age and an objective method for its assessment. Pediatr. Clin. North Am. 13: 835848.

Usher $\mathbb{R}$, McLean $F(1969)$ : Intrauterine growth of live-born Caucasian infants at sea level: standards obtained from measurements in 7 dimensions of infants born between 25 and 44 weeks of gestation. J. Pediatr. 74: 901-910.

Usher RH (1970): C1inical and therapeutic aspects of fetal malnutrition. Pediatr. Clin. North Am. 17: 169-183. 
Usher RH, McLean FH (1974): Momal fetal growth and the significance of fetal growth retardation. In: Sclentific Foundations of Paedidrics. Eds. JA Davis and J Dobbing. Heinemann, London, pp. 69-80.

Vergluys C (1980)" Keuze van voor Nederland brulkbare perinatale groelcurven. T. Kindergeneesk. 48: 158-167.

Warkany J. Monroe BB, Sutherland BS (1961): Intrauterine growth retardation. Am* J. Dis. Child. 102: 249-279.

Warshaw JB (1974): Factors affecting fetal growth. In: Modern perinatal medicine. Ed. L Gluck. Year Book Medical Publishers. Chilcago, pp. $335-345$.

Warshaw JB (1979): The growth retarded fetus. Clin. Perinatol. 6: $353-363$

Waterson AP (1979): Virus infections (other than rubella) during pregnancy. Br. Med. J. 2: 564-566.

Wharton BA, Foulds JW, Fraser ID, Pennock CA (1971): Amniotic fluid total hydroxyproline and intrauterine growth. Brit. J. Obstet. Gynaecol. 78: 791-797.

Wharton BA, Gough G, Williams A, Kitts S, Pennock CA (1972): Urinary total hydroxyproline: creatinine ratio. Range of normal, and clinical application in British children. Arch. Dis. Child. 47: 74-79.

Wharton BA, Gough $G$, Pennock CA (1973): The relationship of height and weight velocities of adolescent boys to the total hydroxyprolinescreatinine ratio in their random urines. clin. Science $44=359-365$.

Whitehead RG (1965): Hydroxyproline:creatinine ratio as an index of nutritional status and rate of growth. The Lancet 2:567570 .

Whitehead RG (1969): The assessment of nutritional status in protein-malnourished children. Proc. Nutr. Soc. 28: 1-16.

Widdowson EM, MCCance RA (1963): The effect of finite periods of 
undernutrition at different ages on the composition and ubsequent development of the rat. Proc. R. Soc. Lond. (Biol.) $158: 329-342$.

Widdowson EM (1970): Harmony of growth. The Lancet 1: $901-905$. Widdowson EM (1974 a): Changes in body proportions and composition during growth. In: scientific foundations of paediatrics. Eds. I Davis and $J$ Dobbing. Heinemann, London, pp. 153-163.

Widdowson EM (1974 b): Imnedilate and long-term consequences of being large or small at birth: A comparative approach. In: Size at birth. Eds. K Elliott and J Knight. Ciba Fan. Symp. 27. Elseviex, Amsterdam, pp. 65-76.

Wigglesworth JS (1967): Pathological and experimental aspects of foetal growth retardation. Proc. R. Soc. Med. 60: 879-891. Winick M, Noble A (1966): Cellular response in rats auring malnutrition at various ages. J. Nutr. 89: 300-306.

Wirth FH, Goldberg KE, Lubchenco LO (1979): Neonatal hyperviscosity: I Incidence. Pediatrics 63: 833-836.

Wright EV (1976): Chromosomes and human fetal development. In: The biology of human fetal growth. Eds. DF Roberts and $M$ Thomson. Taylor and Francis, London, pp. 236-252.

Younoszal MK, Haworth JC (1968): Excretion of hydroxyproline in urine by premature and normal full-term infants and those with intrauterine growth retardation during the filrat three days of 1ife. Pediatr. Res. $2: 17-21$.

Younoszai MK, Kacic A, Dilling L, and Haworth JC (1969): Urinary hydroxyproline:creatinine ratio in normal term, pre-term, and growth-retarded infants. Arch. Dis. Child. 44:517-520* 


\section{PUBLICATIONS PRESENTED IN THIS THESIS:}

Publication I

Intratuterine malnutrition and urinary hydroxyproline excretion.

F.J. Walther and L.H.J. Ramaekers: Journal of Perinatal Medicine $8(1980), 272-277$.

Publication II

The ponderal index as a measure of the nutritional status at birth and its relation to some aspects of neonatal morbidity. F.J. Walther and L.H.J. Ramaekers: Journal of Perinatal Medicine $10(1982), 42-47$.

Publication III

Neonatal morbidity of S.G.A. infants in relation to their nutritional status at birth.

F.J. Walther and L.H.J. Ramaekers: Acta Paediatrica Scandinavica $71(1982), 437-440$.

Publication IV

Growth in early childhood of newborns affected by disproportionate intraterine growth retardation.

F.J. Walther and L.H.J. Ramaekers: Acta Paediatrica Scandinavica $71(1982), 651-656$. 
Publication $v$

Skeletal maturity at birth and at the age of 3 years of infants malnourished in utero.

F.J. Walther, L.H.J. Ramaekers, J.M.A. van Engelshoven: Early Euman Development 5 (1981), 139-143.

Publication VI

Developmental aspects of subacute fetal aistress: Behaviour problems and neurological dysfunction.

F.J. Walther and L.H.J. Ramaekers: Early Human Development 6 (1982), $1-10$.

Publication VII

Language development at the age of 3 years of infant: malnourished in utero.

F.J. Walther and L.H.J. Ramaekers. Neuropaediatrics 13 (1982), $77-81$. 


\section{MALNUTRITION AND \\ URINARY HYDROXYPROLINE EXCRETION}

\section{Summary}

The purpose of this study was to investigate if the excretion of hydroxyproline in the first urine of newborns could be used as a blochemical parameter for the diagnosis of intrauterine malnutrition preliminary to investigation of amniotic fluid. Hydroxyproline in the urine 1 s considered a reliable index of bone collagen metabolism and correlates well with skeletal growth which is retarded $\mathbb{i n}$ intrauterine malnutrition (12).

A precisely defined diagnosis of malnutrition and its severity is necessary first of al1. In order to quantify the degree of thalnutrition of newborns the deviation of the ponderal index (100 x weight in grams/length in centimeters) ${ }^{3}$ ) from "nomal" (defined as the 50 centile of the data of Lubchenco et al. (9)1 was used. By chemical analysis the total hydroxyproline excretion in the first urine sample passed after birth was determined as well as the creatinine excretion. As creatinine excretion is correlated with body size and muscle mass, the total hydroxyproline (mmol/l) / creatinine (mmol/1) or THP/Cr. ratio was used instead of the absolute values of the total hydroxyproline excretion as it gives more conslstent results for subjects of the same biological age. single samples of urine could be used because they show a good correlation with 24-hour collections of urine.

50 Selected normal and malnourished term infants were investigated, all were Caucasian babies without congenital malformations, congenital. infections, and chromosomal abnormalities, whereas smal1-for-dates due to chronic fetal distress and genetically determined small-for-dates were excluded. No correlation 
between the degree of intrauterine malnutrition (definea as the deviation of the ponderal index from 'normal growth') and the THP/Cr. ratio could be established (FIg. 1). Other studies, not defining the degree of intraterine malnutrition, show a conslderable overlap between normal and malnourished term infants. This study proves that urinary hydroxyproline excretion cannot be used clinically as a measure of intraterine malnutrition of the newborn, probably because intrauterine growth is retarded already under normal conditions in the last trimester (5). The normal range of urinary hydroxyproline excretion being already wide. starvation does not add a measurable and significant decrease to the hydroxyproline excretion.

\section{Introduction}

Both amniotic fluid and urine of newborns contain hydroxyproline, an amino-acid related to the collagen metabolism and particularly the collagen matrix. Phases of rapid growth of the human body are accompanied by a high collagen turnower resulting in an increased excretion of hydroxyproline in the urine, whereas malnourishment and retarded growth lead to a diminished output $(11,15)$.

In normal pregnancy the total hydroxyproline/creatinine (THP/ Cr.) ratio in amniotic fluid shows a rise around 15-19 week of gestation followed by a prolonged fall towards term (13). This coincides with the rapid increase in length of the fetus.

Theoretically the THP/Cr. ratio in amiotic fluid might be used as a biochemical measure of assessing intrauterine growth. This was investigated in a preliminary report by Bissender et al. (2) showing significant lower amnlotic THP values in European pregnancies with intrauterine malnourished infants in comparison with pregnancies with normally grown babies. But was there was a considerable averlap of the values, the clinical wse of THP estimation without further evaluation was considered to be 
Iimited.

Becaume mniotic fluid is not readily available for research purposes, the first urine after birth can be used instead. This was done by Younoszal et al. (16). They could not demonstrate aignificant differences in the first specimen of urine after birth in normal term infants and malnourished newborns. No data on the degree of malnourishment are available however.

Intrauterine malnutrition is the most Erequent cause of S.G.A., and these infants are usually recognizable clinically as being wasted and showing disproportional growth. This dissociation of weight and length can be objectively determined by the use of the Ponderal Index (P.I.) of Rohrer (100 $x$ weight in grams/(length in centimeters $)^{3}$ ). By comparison of the P.I. with the 50 centile of the data of Lubchenco et al. (9) (arbitrarily considered as beling the index of appropriate normal growth) the degree of intrauterine malnutrition can be quantified according to Roord and Ramaekers (11). Furthermore these authors concluded. that though the ponderal index can be used as a measure of malnutrition, birthweight alone is not a correct parameter for the definition of starvation. Therefore the malnourished newborn can have a weight well above the small-for-gestational age (S.G.A.) borderline of the loth centlle and still be undernourished.

In this study we tried to establish a correlation between the degree of intrauterine malnutrition and the THP/Cr. ratio in the first urine volded by 50 selected term newborns. This in order to find out if hydroxyproline excretion can be used as a biochemicall parameter for diagnosis of intrauterine malnutrition by investigating the amniotic fluid in a later trial.

Material and Methods

The patients consisted of 50 newborn singletons of both sexes and from all gocial classes, with a nutritional state varying from 
severe malnourishment to normal growth. They were borm at a gestational age of 38 or more weeks. Those showing algns of wasting were admitted to the Department of Neonatology for a variety of reasons, the others were healthy newborns of the Obstetric Department. Gestational age was calculated from the first day of the last menstrual period and verifled by the Dubowitz score, those showing a difference of more than one week were excluded from the study.

Excluded were non-Caucasians and infants with congenital malformations, congenital infections, chromosomal abnormalities and small-for-ates aue to chronic fetal distress (5). Rohrer" ponderal index $\left(100 \times \mathrm{W} / \mathrm{L}^{3}\right)$ was determined and the deviation from 'normal' (50 centile of the data of Lubchenco et al. (91)) calculated according to Roord and Ramaekers (11).

Immediately after birth first urine samples were collected in plastic bags, which were emptied as soons as they contained 15 mi. of urine, a quantity always met at the first voidance. Urine was stored frozen at $-10^{\circ} \mathrm{C}$. Creatinine in the urine was determined by the classical method of Jaffe after dialysis to remove non specific chromagens of low molecular origin.

Total urinary hydroxyproline was estimated as described by Goverde and Veenkamp (3). which method is in good agreement with that of Prockop-kivirikko (7). The ratios of total hydroxyproline $($ mol/1)/creatinime $(m m o l / 1)$ were calculated. Single samples were used as Younoszai et a1. (17) and Howells et al. (6) showed a good correlation between THP/Cr. ratios in 24 hourg collections and in random urine samples. 24-Hour sampling seemed therefore unnecessary.

\section{Results}

In analyzing the 50 mewborns proved to show a continum of normal growth to an increasing degree of wasting whereas 3 newborns also 
Bhowed postmature characteristics (Clifford* stages I/III).

The mean and range for welght and height are given in $\mathrm{Tab}$. $I$, the distribution on the percentile charts of the Rohrer index (9) in Tab. II. Fig. 1 represents the correlation between deviation from "normal" ponderal index 150 centile for the individual gestational week) and the THP/Cr. ratio in the first urine volded after birth. No significant relationship between those two parameters could be established la11 points were used in calculating the regression equation: $Y=0.115-0.038 \mathrm{X} ; \mathrm{r}=-0.141, \mathrm{n}=50$, M.S.). Also no correlation was found between the absolute THP values or $\mathrm{THP} / \mathrm{Cr}$. ratio and weight, length and body surface at birth. Girls tended to a lower $\mathrm{THP} / \mathrm{Cr}$. ratio than boys 10.108

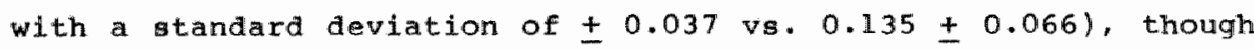

Table I Mean and range of weight and length of the study group.

\begin{tabular}{|l|l|l|l|l|}
\hline \multicolumn{2}{|l|}{} & \multicolumn{2}{l|}{ Weight } & \multicolumn{2}{l|}{ Length } \\
\hline \multicolumn{2}{|l|}{$g$} & cm \\
\cline { 2 - 5 } & mean & range & mean & range \\
\hline Study group & 3071 & $1630-4130$ & 50.3 & $43.1-55.0$ \\
\hline
\end{tabular}

Table II Distribution of the study group on the percentile charts of the Rohrer index.

\begin{tabular}{|c|c|}
\hline Percentile ranges & Number of studied newborns \\
\hline P50-75 & 6 \\
P25-50 & 17 \\
P10-25 & 16 \\
P 10 & 11 \\
& \\
Tota1 & 50 \\
\hline
\end{tabular}

*lifford SH (1954): Postmaturity - with placental dysfunction. J. Pediatr. 44: 1-13. 
these differences were not statistically significant ( $P, 0.05$ ). The mean THP/Cr. ratio of the whole group amounted to 0.124 with a range of $0.040-0.331$ and a standard deviation of 0.055 .

\section{Discussion}

The THP/Cr. ratio has been shown to be related to collagen turnover and to reflect the rate of growth in children. The largest amounts of hydroxyproline are excreted with the urine during the first three months of life. Thereafter it falis quickly till 12 monthis of age followed by a much slower decrease until pubertal growth spurt $(4,14)$.

The ratio of total hydroxyproline/creatinine is used instead of the absolute values of the total urinary hydroxyproline excretion because it gives more consistent results for subjects of the same biological age, as creatinine excretion is correlated with

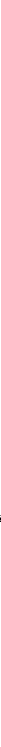

Fig. 1 Correlation between Rohrer index deviation from 'normal' and total hydroxyproline (mol/1)/creatinine (mmol/1) ratio in the first urine passed by newborns. 
body ize and muscle mass (1). Whereas in children over 6 months of age the major portion of urinary hydroxyproline is peptidebound and only 5 or less is in the free form, infants during the first three months of life excrete about a third of the total hyaroxyproline in the free form $(4)$.

Klujber et al. (B) found that premature infants, intrauterine malnourished tern infants and normally grown infamts excreted about the ame proportion of free hydroxyproline during the first three weeks of life, which means that total urinary hydroxyproline measurements can be used in that period.

Although our values are in good agreement with the values found by Younoszai et al. (16) we could not find any correlation between the degree of growth retardation and THP excretion. The explanation for this is probably the fact that intrauterine growth is retarded under normal circumstances in the last trimester according to Gruenwald (5). The normal range of urinary THP excretion being already wide, starvation does not add a measurable and significant decrease to THP excretion.

other parameters have to be searched for "as prenatal diagnosis of intrauterine malnutrition by means of biachemical analysia of amniotic fluld seems important. More promising may be the amilotic or urinary 3-methyl-histidine excretion. This amino-acid 18 almost exclusively present in skeletal muscle protelns and is excreted without further metabolism or recycling during their catabollim (10) in rats. However, the afficult quantitative estimation of this amino-acid hampers its clinical research up ti11 now.

\section{References}

1. Alligon DJ, walker A, Smith QT (1966): Urinary hydroxyprolinescreatinine ratio of normal humans at various ages. Clin. Chim. Acta 14: 729 . 
2. Bissenden JG, scott $P$, Wharton $B A$ (1978): Assessment of nutrition status of the fetus by examination of amniotic fluid. Arch. Dis. Child. 53:263.

3. Goverde BC, Veenixamp FJN (1972): Routine assay of total urinary hydroxyproline based on resincatalysed hydrolysis. Clin. Chim. Acta $41: 29$.

4. Graf U, Vest $M(1971)$ : Zur normalen Hydroxyprolinausscheidung im Urin bei Säuglingen, Kindern und Adoleszenten. $z$. Kinderheilk. 110: 128 .

5. Gruenwald P (1974): Pathology of the deprived fetus and its supply Iine. In: Size at birth. 27th Ciba Fdn. Symp. 3-26.

6. Howells GR, Wharton BA, McCance RA (1967): Value of hydroxyproline indices in malnutrition. The Lancet I: 1082 .

7. Kivirikko KI, Laitinen 0, Prockop DJ (1967): Modification of a specific assay for hydroxyproline in urine. Anal. Biochem. 19: 249.

8. Klujber I, Mestyán J, Sulyok E, Soltész G (1972): Urinary hydroxyproline excretion in normally grown and growth-retarded newborn infants. Blol. Neonate 20: 196.

9. Lubchenco Lo, Hansmann C, Boyd E (1966): Intrauterine growth in length and head circumference as estimated from live births at gestational ages from 26 till 42 weeks. Pediatrica $37: 403$.

10. Nagabhushan VS, Rao BS (1976): Metaboliam of 3-methyl hist1dine in experimentally induced protein-energy malnutrition in rats: Urinary excretion and muscle content of 3-methyl histidine. Life Sciences $18: 639$.

11. Roord JJ, Ramaekers LHJ (1978): Quantification of intra-uterine malnutrition. Bllol. Neonate 33: 273 .

12. Roord JJ, Ramaekers LHJ, Van Engelshoven JMA (1978): Intrauterine malnutrition and skeletal retardation. Blol. Neonate $34: 167$. 
13. Wharton BA, Foulds JW, Fraser ID, Pennock CA (1971): Amniotic fluia total hydroxyproline and intrauterine growth. Brit. J. Obstet. Gynacol. 78: 791 .

14. Wharton BA, Gough G, Williams A, Kitts 5, Pennock CA (1972): Urinary total hydroxyproline:creatinine ratio range of normal and clinical application in British chilaren. Arch. Dis. Child. 47: 74 .

15. Whitehead RG (1969): The assessment of nutritional status in proteln-malnourished children. Proc. Nutr. Soc. $28: \mathbb{1}$.

16. Younoszai MK, Haworth JC (1968): Excretion of hydroxyproline in urine by premature and normal full-term infants and those with intraterine growth retardation during the first three days of life. Pediat. Res. $2: 1.7$.

17. Younoszai MK, Kacic A, Dililing L, Haworth JC (1969): Urinary hydroxyprolinescreatinine ratio in normal ter, pre-term and growth-retarded infants. Arch. Dis. Child. 44: 517. 


\section{PUBLICATION II: THE PONDERAL INDEX AS A MEASURE OF THE \\ NUTRITIONAL STATUS AT \\ BIRTH AND ITS RELATION TO \\ SOME ASPECTS OF NEONATAL MORBIDITY.}

\section{Summary}

The purpose of this study was to investigate if the ponderal index might be a better measure to predict neonatal morbidity than birthwelght for gestational age. The ponderal index (100 $x$ $\left.W / L^{3}\right)$ assesses whether an infant appears relatively 'fat' or "thin" at birth by quantification of the dissociation of weight and length and is of great help to recognize wasted infants irrespective of their distribution on the percentile lines of birthwelight for gestational age. Except that the ponderal index is more informative about the nutritional status at birth, it is: relatively independent of race, sex, birthrank, and gestational age at term (11). Therefore the ponderal index is an easier tool for rapid diagnosis of intrauterine malnutrition at birth than birthweight for gestational age. The relation between the ponderal index and neonatal morbidity and between birthweight and neonatal morbidity was studied in a group of 500 term infants of various birthweight. The distribution of the infanta by birthweight differed significantly from the distribution by ponderal. index (Tab. I): whereas their average birthweight centred around the 25 th percentile (7), their average ponderal index centred close by the 45 th percentile (11). One thind of the S.G.A. infants and $8 \%$ of the A.G.A. infants were wasted. 6 Common neonatal problems were investigated: asphyxia, acidosis, hypoglycemia, hypothermia, hyperviscosity and hyperbilirubinemia. Asphyxia, acidosis, hypoglycemia, hypothermia, and hyperviscosity were 
signiflcantly more frequently diagnosed in (wasted) infants with a mall ponderal Index, (Tab. II), whereas only hypoglycemia, hypothermia, and hyperviscosity could be related to a low birthweight for geatational age (Tab. III). Especially the combination of wating and underweight pointed to a high incidence of neonatal morbidity (Tab. IV). Hyperbilirubinemia was rare in both wasted and underweight infants.

It seems warrantable to conclude that like birthwelght the ponderal Index is a reliable measure of neonatal morbidity. Therefore the calculation of the ponderal index at birth deserves a place beside the estimation of birthwelght for gestational age.

\section{Introduction}

Intrauterine malnutrition is generally defined by low birthweight for a gestational age calculated from the last normal period and corroborated by olinical assessment of the infant at bilth (16). However, not all infants affected by intrauterine malnutrition will be included in such a definition as an unknown percentage of newborns whose birthwelght does not fall below the normal for gestational age, have not achieved their full growth potential (3). Clinically these infants will be recognized by manifest soft tisue logs, urually called 'wasting" .

To facilitate the diagnosis of intraterine malnutrition at birth it is useful to incorporate body length in the assessment and to calculate Rohrer"s ponderal index $\left(100 \times \mathrm{w} / \mathrm{L}^{3}\right)$ which adesses whether an infant appears relatively 'fat' or 'thin' by quantification of the dissociation of weight and length (3, 12). Wasted infants will show a relatively small ponderal index irrespective of their distribution on the percentile lines of birthweight for gestational age. Lubchenco et al. (9) and Miller and Hassanein (11) provided standard curves of the ponderal index (P.I.) for gestational age. Since Gruenwald (3) widely explained 
its benefits several authors have used the P.I. as criterion to define the state of nutrition of their study groups. These studies have demonstrated that the P.I. at birth is correlated with skinfold thickness (11), skeletal retardation (13, 17), postnatal growth $(1,17)$ and behaviour problems and neurological dysfunction at pre-school age (18).

It is known that small-for-gestational age (S.G.A.) infants (whose birthweight is below the loth percentile for gestational age) have a higher incidence of asphyxia " hypoglycemia (19), hypothermia (14), and hyperviscosity (4, 19) in the neonatal period. Unlike birthweight the relation between the P.I. (as a quantitative measure of the nutritional status at birth) and neonatal morbidity has not yet been properly evaluated. For that purpose the incidence of 6 common neonatal problems (asphyxia, acidosis, hypothermia, hypoglycemia, hyperviscosity, and hyperbilirubinemia) was examined in a group of 'unselected' term infants in relation to birthweight and to p.I. distribution.

\section{Material and Methods}

The subjects in this study consisted of 500 consecutive live-born infants admitted to the neonatal ward directly after birth. All were Caucasian singletons born at a gestational age between 38 and 42 weeks, as verified by the Dubowitz score (2). Excluded were infants of diabetic mothers, infants with Rh or $A B O$ hemoIytic disease, and infants wh fetal diseases (congenital infections and anomalies, chromosomal aberrations). 55 of the infants were admitted for observation after an artificial delivery, 228 because of signs of intrauterine malnutrition, 8 because of overweight, and 158 for a variety of reagons.

Weight and length were measured after birth using methods previlously described (12). of each infant the percentlle of birthweight for gestational age was established allowing for sex 
and bicth order (7). Furthermore the P.I. (100 weight in grams/ length ${ }^{3}$ in $\mathrm{cm}$ ) was calculated for each infant and its distribution on the percentile charts of Miller and Hassanein (II) was established. The next information of all infants was collected: Apgar scores at 1 and 5 minutes after birth; arterial umbilical pH; rectal temperature at admission; blood glucose levels at $I$. $2,3,6,12,24$ and 48 hours after birth; venous haematocrit levels if capillary haematocrit vallues from a pre-warmed heel amounted to $70 \%$ or more at 1 and/or 3 hours after birth (19); and serum bilirubin levels in case of neonatal jaundice. The variables assessed in this study were defined as follows. Neonatal asphyxia was diagnosed in infants who had an Apgar score of $0-3$ at 1 and/or 5 minutes and required at least one minute of positive pressure ventilation before respiration occurred. Acidosis was defined as an arterial umbilical pH $<7.09$ (5). Hypothermia was defined as an admission rectal temperature $<35.5^{\circ} \mathrm{C}$. Hypoglycemia was defined as a blood sugar concentration $\leqslant 1.6$ mol $1 /$. Hyperviscosity was defined as a venous haematocrit $\geqslant 65 \%$. Hyperbilirubinemia was defined as a total bilirubin concentration $>200 \mu m o l / 1$. As a routine clamping of the umbilical cord took pllace before 1 minute after birth of the infants. All vital problems were managed by a paediatrician in the delivery room. All infants in the study were subjected to an early feeding practice. The distribution of discrete variables was compared by chisquare.

\section{Results}

The ditribution of the infants by birthweight for gestational age and by P.I. is presented in Tab. I. The distribution by birthweight differs significantly from the distribution by ponderal index. Whereas 119 of the 500 (23.88) infants had a birthweight below the loth percentile for gestational age land were 
S.G.A.), only 80 of the $500(16.0 \%)$ infants had a P.I. below the 10th percentile (and were wated). As 46 of the $500(9.28)$ infants had both a birthweight and a P.I. below the 1oth percentiles, there exists a firm correlation between these two parameters $\left(\mathrm{X}^{2}=59.639, \mathrm{DF}=1, \mathrm{P}(0.0005)\right.$.

$73 / 119$ (61.38) S.G.A. infants had a P.I. on or above the 10th percentile and were not severely wasted. 34 Infants had a P.I. below the loth percentile and a birthweight on or between the loth and 90 th percentiles, indicating that 8.18 of the A.G.A. (appropriate-for-gestational age) infants were clinically wasted.

Tab. II shows that asphyxia $\left(x^{2}=12.921, D F=5, p(0.025)\right.$, acidosis $\left(x^{2}=11.674, D F=5, p<0.05\right)$, hypoglycemia $\left(x^{2}=\right.$ 14.671, $\mathrm{DF}=5, \mathrm{p}<0.025)$, hypothermia $\left(\mathrm{X}^{2}=37.221, \mathrm{DF}=5, \mathrm{p}<\right.$ $0.0005)$, and hyperviscosity $\left(x^{2}=17.235, D F=5, p(0.005)\right.$ were significantly more often diagnosed in infants with a small P.I. A statistically significant correlation between the P.I. and hyperbilirubinemia was absent. As 11 of the 42 infants with asphyxia also presented acidosis, a significant correlation between acidosis and asphyxia could be established $\left\langle\mathrm{x}^{2}=15.845, \mathrm{DF}=1\right.$, $p(0.005)$.

Infants whose birthweight for gestational age is low, had a higher incidence of hypoglycemia $\left(x^{2}=12.327, D F=5, p(0.05)\right.$, hypothermia $\left(\mathrm{X}^{2}=33.484, \mathrm{DF}=5, \mathrm{p}<0.0005\right)$ and hyperviscosity $\left(X^{2}=44.680, D F=5, p<0.0005\right)$, (Tab. III).

Asphyxia, acidosis, and hyperbilirubinemia were not igniticantly related to $5.6 . A$. Infants, though the incidence of asphyxia was slightly higher in S.G.A. infants.

One or more of the 6 investigated neonatal problems were diagnosed in $57 / 119(47.98)$ S.G.A. infants, in $41 / 80$ (51.28) infants with a P.I. below the 10th percentile, and in $30 / 46$ (65.2\%) infants whose birthweight and P.I. fell below the loth percentiles. 
Tab. IV point out that in general infants with a birthweight and a P.I. below the loth percentlles showed more often neonatal problems than wasted A.G.A. Infants and non-wasted S.G.A. infants. Hyperviscosity is an exception to this rule as it was more often geen in both wasted and non-wasted S.G.A. Infants. Hyperbilirubinemid centred around the 50th percentiles of both birthweight and the ponderal 1 index and its incidence was not increased in any of the 3 subgroups defined above.

Table I Distribution of the study group on the percentile charts of birthweight and of the ponderal index (percentages)

\begin{tabular}{l|ccccccc}
\hline $\begin{array}{l}\text { Birth- } \\
\text { weilght }\end{array}$ & $<10$ & $10-25$ & $26-50$ & $51-75$ & $76-90$ & $>90$ & $\begin{array}{l}\text { Total } \\
\text { (100\%) }\end{array}$ \\
\hline$<10$ & 46 & 22 & 5 & 5 & 1 & 1 & $80(16.0 \%)$ \\
$10-25$ & 24 & 23 & 16 & 9 & 1 & 1 & $74(14.8 \%)$ \\
$26-50$ & 29 & 37 & 33 & 30 & 7 & 2 & $138(27.6 \%)$ \\
$51-75$ & 15 & 25 & 20 & 33 & 23 & 16 & $132(26.4 \%)$ \\
$76-90$ & 3 & 4 & 7 & 8 & 12 & 8 & $42(8.4 \%)$ \\
$>90$ & 2 & 3 & 2 & 8 & 7 & 12 & $34(6.8 \%)$ \\
\hline Total $(100 \%)$ & 119 & 114 & 83 & 93 & 51 & 40 & 500 \\
& $(23.8 \%)$ & $(22.8 \%)$ & $(16.6 \%)$ & $(18.6 \%)$ & $(10.2 \%)$ & $(8.0 \%)$ & \\
\hline
\end{tabular}

Table II Distribution of neonatal morbidity on the percentile block of the ponderal index (percentages of the percentile blocks)

\begin{tabular}{|c|c|c|c|c|c|c|c|}
\hline $\begin{array}{l}\text { neatal } \\
\text { morbidity }\end{array}$ & $\begin{array}{l}<10 \\
n=80\end{array}$ & $\begin{array}{l}10-25 \\
n=74\end{array}$ & $\begin{array}{l}26-50 \\
n=138\end{array}$ & $\begin{array}{l}51-75 \\
n=132\end{array}$ & $\begin{array}{l}76-90 \\
n=42\end{array}$ & $\begin{array}{l}>90 \\
n_{i}=34\end{array}$ & $\begin{array}{l}\text { Total } \\
n=500\end{array}$ \\
\hline Asphy xía & $14(17.5)$ & $6(8.1)$ & $11(8.0)$ & $9(6.8)$ & $2(4.8)$ & $0(0)$ & $42(8.4)$ \\
\hline Achollosís & $15(18.7)$ & $7(9.4)$ & $10(7.2)$ & $10(7.6)$ & $3(7,1)$ & $1(2.9)$ & $460.2)$ \\
\hline Hyperviscosity & $10(12.5)$ & $9(12.2)$ & $9(6.5)$ & $1(0.7)$ & $1(2.4)$ & $2 \quad(5,9)$ & $32(6,4)$ \\
\hline Hy pogly omia & $7(8.7)$ & 1) (1.3) & $2(1.4)$ & $4(3.0)$ & $4(9.5)$ & $0(0)$ & $18(3.6)$ \\
\hline Hy pother mia & $19(23.7)$ & $5 \quad(6.7)$ & $7(5.1)$ & $6(4.5)$ & $1(2.4)$ & $0(0)$ & $38(7.6)$ \\
\hline Hyperbilirubinemia & $4(5.0)$ & $0 \quad(0)$ & $10(7.2)$ & $11(8.3)$ & $3(7.1)$ & $0(0)$ & $28(5.6)$ \\
\hline
\end{tabular}


Table III Distribution of neonatal morbidity on the percentile blocks of birthweight for gestational age (percentages of the percentile blocks)

\begin{tabular}{|c|c|c|c|c|c|c|c|}
\hline Birth- & $<10$ & $10-25$ & $26-50$ & $51-75$ & $76-90$ & $>90$ & total \\
\hline morbidity & $\mathrm{n}=119$ & $\mathrm{na}=1114$ & $m=83$ & $n=93$ & $\mathrm{n}=51$ & $n=40$ & $n=500$ \\
\hline Asphyxia & $17(14.3)$ & $6 \quad(5.3)$ & $9(10.8)$ & $4(4.3)$ & $3 \quad(5.9)$ & $3 \quad(7.5)$ & $42 .(8.4)$ \\
\hline Acidosis & $15(12.6)$ & $12(10.5)$ & $6(7.2)$ & $3(3.2)$ & $6(11.8)$ & $4(10.0)$ & $46(9.2)$ \\
\hline Hy perviscosity & $23(19.3)$ & $4(3.5)$ & $3 \quad(3.6)$ & $1(\mathbb{1} .1)$ & $1 \quad(2.0)$ & $0 \quad(0)$ & $32(6.4)$ \\
\hline Hy poglycemia & $5 \quad(4.2)$ & $4 \quad(3.5)$ & $2 \quad(2.4)$ & $2(2.1)$ & $0 \quad(0)$ & $5(125)$ & $18(3.6)$ \\
\hline Hypothermia & $22(18.5)$ & $11 \quad 9.6\rangle$ & $2(2.4)$ & $2(2.1)$ & $1 \quad(2.0)$ & $0 \quad(0)$ & $38(7.6)$ \\
\hline Hyperbilirubinemia & $6 \quad(5.0)$ & $4 \quad(3.5)$ & $5 \quad(6.0)$ & $9(9.7)$ & $2(3.9)$ & $2(5.0)$ & $28(5.6)$ \\
\hline
\end{tabular}

Table IV Neonatal morbidity in 3 subgroups (percentages)

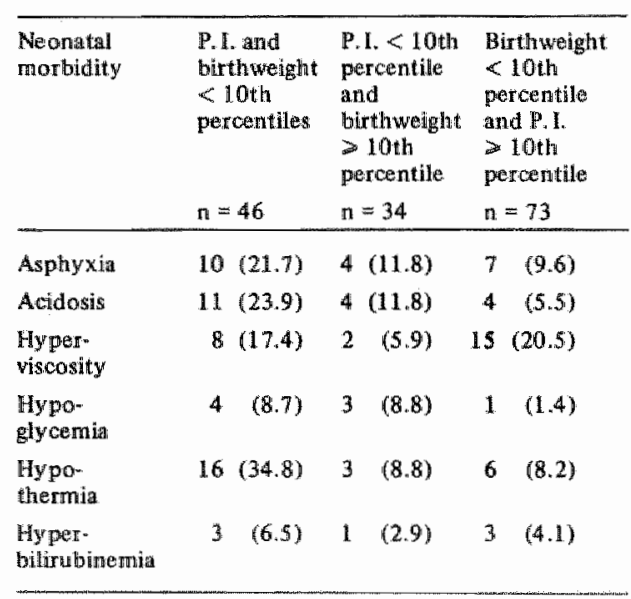

\section{Discussion}

Except the indicated limitations, assegsment of fetal growth by means of birthweight for gestational age regularly throws up problems in daily practice. For example insufficient information about the gestational age may hamper the interpretation of birthweight, whereas infants of different race, sex, and birthrank cannot be compared without the consultation of different atandara graphs of intrauterine growth. The use of the ponderal index may then be of great help as it is relatively independent of race. 
wex, birthrank, and gestational age at term (11). As the P.I. also point to wated infants whose birthweight is appropriate for gestational age (about 8 in this study) and quantifies Intraterine malnutrition, its advantages are obvious in daily practice. However, birthweight for gestational age has yielded important information about the relationship between intrauterine growth retardation and neonatal morbidity and mortality. It continues therefore to deserve its place in the classification of infants at birth. In need of more information about the nutritional status at birth it is advantageous to consider the P.I.

of the six neonatal problems assessed in this study only hypoglycemia has been analysed in relation to the p.I. before. Jăraí et al. (6) investigated a mixed group of preterm, term, and postterm S.G.A. infants using different indices of body proportions and pointed to the slignificance of soft tissue wasting (rather than low bilrthweight for gestational age itself) in the development and diagnosis of neonatal hypoglycemia. The same conclusion emerges from this study. But it also shows that hypoglycemia occurred often in overweight infants (P.I.) 75th percentile and/or birthweight 90 th percentile) whose mothers were free from diabetes. The cause of this phenomenon remained unGlear.

Generally speaking it can be said that the P.I. is equal to or surpasses birthweight for gestational age as a tool to predict neonatal problems like asphyxia, acidosis, hypoglycemia, and hypothermia. Though hyperviscosity is more common in infants with a small P.I." It accurs especially in those infants whose bifthwelght falls below the 10th percentile. A proper explanation of this fact 1 s unknown to us and will need further study.

Though low values of the arterial umbilical pH correlated well with a low Apgar score (as shown by Huisjes and Aarnoudse in a recent study (5)) and the necessity of positive pressure ventila- 
tion, this relation was not complete as only one fourth of the asphyxia cases presented with severe acldosis and the other way round. This phenomenon has been laid down in a publication of Litschgi et al. (8) who described that especially the comblnation of a low Apgar score and acidosis resulted in an increased incidence of neurological morbidity. As this combination was mostly diagnosed in the underweight infants who were wasted, this group will be at high risk of developmental problems as a result of this problem. Hyperbilirubinemia is relatively rare in wasted and underweight infants. This is probably due to an advanced stage of functional maturity of the liver post partum brought on by a large blood volume and a higher haematocrit (15).

\section{References}

1. Davies DP, Platts P, Pritchard JM, Wilkinson PW (1979): Nutritional status of light-for-date lifants at birth and its influence on early postnatal growth. Arch. Dis. Child. 54: 703.

2. Dubowitz L, Dubowitz V, Golaberg C (1970): Clinical assessment of gestational age in the newborn infant. J. Pediatr. $77: 1$.

3. Gruentald P (1974): Pathology of the deprived fetus and its supply line. In: size at birth. 27th Ciba Fan. Symp." Elsevier, Amsterdam, pp. 3-26.

4. Hakanson DO, Oh (1980): Hyperviscosity in the small-forgestational age infant. Biol. Neonate 37: 109 .

5. Huisjes: HJ, Aarnoudse JG (1979): Arterial or venous umbillical pH as a measure of neonatal morbidity? Early fum. Dev. 3: 155 .

6. Jấrai I, Mestyấn J, Schultz K, Lázấr A, Halasz M, Krassy I (1977): Body size and neonatal hypoglycemia in intraterine growth retardation. Early Hum. Dev. 1: 25. 
7. Kloosterman GJ (1970): on intrauterine growth. The gignificance of prenatal care. Int. J. Gynaec. Obstet. $8: 895$.

B. Litschgi M, Beuz $\Im J$, Glatthar $E$ (1974): Aktuelle und prognotische Bedeutung des arterielien Nabelschnur-pH fur die postpartale zustandsdiagnostik. Z. Geburtsh. Perinat. 178: 23.

9. Lubchenco LO, Mansmann $C$, Boyd $\mathrm{E}$ (1966): Intrauterine growth in length and head circumference as estimated from live births at gestational ages from 26 till 42 weeks. Pediatrics $37: 403$.

10. Lubchenco Lo, Bard H (1971): Incidence of hypoglycemia in newborn infants classified by birthweight and gestational age. Pediatrics 47: 831 .

11. Miller HC, Hassanein $K$ (1971): Diagnosis of impaired fetal growth in newborn infants. Pediatries 48: 511 .

12. Roord JJ, Ramaekers LHJ (1978): Quantification of intrauterIne malnutrition. Biol. Neonate 33: 273 .

13. Roord JJ, Ramaekers LHJ, Van Engelshoven JMA (1978): Intrauterine malnutrition and skeletal retardation. Biol. Neonate 34: 167.

14. Sinclair JC (1970): Heat production and thermoregulation in the mal1-for-date infant. Pediatr. Clin. North Am. 17: 147.

15. Stockhausen HB $v$, Struve $M$ (1979): Investigation of accelerated metabolic function in small for gestational age inEants. Eur. I. Pediatr. 132: 169.

16. Usher RH (1970): Clinical and therapeutic aspects of fetal nutrition. Pediatr. Clin. North Am. 17: 169.

17. Walther FJ, Ramaekers IHJ, Van Engelshoven JMA (1981): Ske1etal maturity at birth and at the age of 3 years of infants malnourished in utero. Eraly Hum. Dev. 5: 139.

18. Walther FJ, Ramaekers LHJ (1982): Developmental aspects af subacute fetal distress: Behaviour problems and neurological 
aysfunction. Barly Hum. Dev, 6: 1 .

19. Wirth FH, Goldberg KE, Lubchenco LO (1979)* Neonatal hyperviscosity: I Incidence. Pediatrics 63: 833. 


\section{PUBLICATION III: NEONATAL MORBIDITY OF S.G.A. INFANTS IN RELATION TO THEIR NUTRITIONAL STATUS AT BIRTH}

\section{Summary}

46 Consecutively born term infants with a birthweight $\leqslant$ the 2.3 percentile for gestational age were divided into two groups according to their nutritional status at birth quantified by the ponderal index $\left(100 \mathrm{x}\right.$ weight/length $\left.{ }^{3}\right)$. Though all infants had a ponderal index below the 50th percentile, those with a ponderal index below the 3rd percentile (about half of the study group) were more frequently affected by asphyxia, hypoglycemia, hypothermia, and hyperviscosity than their more proportionally grown counterparts. On this account the identification of disproportionally grown small-for-gestational age infants by using the ponderal index as a yardstick of the nutritional status at birth, is necessary because they constitute a high-risk group among small-for-gestational age infants.

\section{Introduction}

sma11-for-gestational age (5.G.A.) infantg are anything but homogeneous in their physical appearance at birth. Some are af normal length but look wasted and are therefore disproportionally mal1, while others are proportionally small. The former infants probably experienced growth retardation during the later weeks of intrauterine life, whereas the latter ones were affected during the whole last trimester. Gruenwald (1) introduced the terms subacute and chronic fetal distress to describe disproportionate and proportionate intraterine growth retardation at birth. Recently Davies et al. (2) established that disproportionally grown S.G.A. infants grow more rapidly after birth than propor- 
tionally grown S.G.A. infants, and emphasized the importance of the nutritional status at birth for prognostic purposes.

As the incidence of both forms of intrauterine growth retardation is not wel known and as the incidence of neonatal morbidity may be different in disproportionally and proportionally grown S.G.A. Infants, we studied a group of S.G.A. Infants whose nutritional status at birth was determined by use of the ponderal index (F.I.).

\section{Subjects and Methods}

Studied were 46 consecutively born term infants whose weight was on or bellow the 2.3 percentile ( 2 S.D. from the mean) for gestational age, allowing for sex and birth order (3) and for maternal height (4). Al1 were Caucasian and singletons. None had any congenital malformation, chromosomal anomaly, or intraturerine infection. The infants were studied prospectively. Weight, length and head circumference were measured after birth using methods previously described (5).

The ponderal index (100 $\mathrm{x}$ weight in grams/length ${ }^{3}$ in $\mathrm{cm}$ ) was calculated for each infant and two groups were identifled using the distribution of the P.I. on the percentile charts of Miller amd Hassanein (6): group 1 included 23 disproportionally grown S.G.A. infants whose P.I.'s were below the 3rd percentile for gestational age, group 2 included 21 proportionally grown S.G.A. Infants whose P.I."s exceeded the 10 th percentile for gestational age. Two infants whose P.I. was between the $3 x d$ and the 10 th percentiles were excluded from the ultimate analysis.

Hypertensive disorders defined by the presence of a diatolic blood pressure exceeding $90 \mathrm{~mm}$ (1) and smoking habits of all mothers were registered. The next ata about the infants were collected: sex; birth rank; gestational age in completed weeks from the mother's last normal menstrual period and verified by 
the Dubowitz score (7): the mode of delivery and the presence of acute fetal distresg at antepartum monitoring: placental weights after removal of the umbilical cord and the membranes.; Apgar scores at 1 and $5 \mathrm{~min}$. after birth and the presence of signs of postasphyxial respiratory distress; arterial umbilical pH; rectal temperature at admisaion to the neonatal ward; blood glucose levels at $1,2,3,6,12,24$ and 48 houra after bỉrth; venous haematocrit levels if caplllary haematocrit values from a prewarmed heel amounted to $70 \%$ or more at 1 and/or 3 hours after birth (8): and serum bilirubin if neonatal jaundice occurred.

Asphyxia was defined as an Apgar score of $0-3$ at $1 \mathrm{~min}$. and/or an arterial umbilical pH below 7.09 (9). Hypoglycemia was defined as a blood sugar concentration below 1.6 mol/1, hyperviscosity as a venous haematocrit exceeding $65 \%$, hypothermia as an admission temperature $\leqslant 35.0^{\circ} \mathrm{C}$, and hyperbilirubinemia as a total bilirubin concentration > $200 \mu$ mol/1. As a routine clamplng of the umbilical cord took place before 1 minute after birth. Vital problems were managed by a paediatrician in the delivery room. All infant in the study were subjected to an early feeding practice.

Statistical significance of differences between means was assessed by the student's t-test. The distribution of discrete vartable in the two groups wa compared by chi-square.

\section{Results}

Twenty-three (508) of the S.G.A. infants were disproportionally grown (group 1) and 21 (468) proportionally grown (group 2). Both groups showed a slight preponderance of boys over girls: in group 1 the ratio boys/girls was 12 : 11 and in group 212 : 9 . Firstborns preponderated over higher birth ranks in group 1 (16/23). but constituted a minority in group $2(6 / 21)$, the difference is statistically significant $(\mathrm{p}<0.01)$. Hypertensive disorders 
Mean values of growth parameters at birth in disproportionally (group 1) and proportionally (group 2) grown S.G.A. infants (standard deviation)

\begin{tabular}{|c|c|c|c|}
\hline & $\begin{array}{l}\text { Group } 1 \\
n=23\end{array}$ & $\begin{array}{l}\text { Group } 2 \\
n=21\end{array}$ & $p$ \\
\hline $\begin{array}{l}\text { Gestational age, whs } \\
\text { Weight. } \mathrm{g} \\
\text { Length, } \mathrm{cm} \\
\text { Ponderal index } \\
\text { Head circumference, cm } \\
\text { Placental weight } \mathrm{g}\end{array}$ & $\begin{array}{l}40.2(1.1) \\
2337(256) \\
48.1(1.8) \\
2.09(0.12) \\
32.7(0.8) \\
388(62)\end{array}$ & $\begin{array}{l}40.0(1.1) \\
2473(160) \\
46.9(1.2) \\
2.38(0.10) \\
32.7(1.1) \\
415(74)\end{array}$ & $\begin{array}{l}\text { N.S. } \\
<0.001 \\
<0.02 \\
<0.001 \\
\text { N.S. } \\
\text { N.S. }\end{array}$ \\
\hline
\end{tabular}

N. N.: not siggnificant.

(23\%) and smoking habits were comparable, the overall incidence of smoking during pregnancy was high (68\%). Table 1 demonstrates that the disproportionally grown infants are lighter and longer than the proportionally grown infants at comparable mean gestational ages, whereas their mean head circumference measurements were comparable. In $56 \%$ of the disproportionate group and in $33 \%$ of the proportionate group placental welights were below the 5 th percentile of gestational age ( $p>0.05)$, mean placental weights did not differ significantly but were relatively low for gestational age (3). Placental insufficiency, defined as necrosis of more than $10 \%$ of the placental parenchyma, was diagnosed in 4 disproportionally grown infants and in none of the proportionate group $(\mathrm{p}<0.05)$.

Artificial deliveries because of signs of acute fetal alstress at monitoring occurred to the same extent in both groups $(5 / 23$ in group 1 and $3 / 21$ in group 2). Asphyxia and congequentilal respiratory distress occurred more often in group $1(7 / 23)$ than in group $2(2 / 21), p<0.05$. The same applied for hypoglycenla $(4 / 23$ in group 1 and $0 / 21$ in group $2, p<0.025)$, hyperviscosity $(7 / 23$ in group 1 and $I / 21$ in group $2, p<0.025)$ and hypothermia (6/23 in group 1 and $1 / 21$ in group $2, p<0.05)$. The mean values of the 
concerning parameters (table 2) present the same picture, though mean arterlal umbilical $\mathrm{pH}$ and capillary haematocrit values fail to reach statistical significance. Hyperbilirubinemia occurred in only 2 infantg in each group.

Table 2 Means of parameter of neonatal morbidity in disproportionally (group 1) and proportionally (group 2) grown S.G.A. Infants (standard deviation)

\begin{tabular}{|c|c|c|c|}
\hline & $\begin{array}{l}\text { Group } 1 \\
n=23\end{array}$ & $\begin{array}{l}\text { Group } 2 \\
n=21\end{array}$ & $p$ \\
\hline Apgar at $1 \mathrm{~min}$ & $6.3(2.2)$ & $7.8(2.1)$ & $<0.05$ \\
\hline Apgiant ant 5 min & $8.6(1.2)$ & $9.4(0.8)$ & $<0.02$ \\
\hline Art umbil. $\mathrm{pH}$ & $7.19(0.14)$ & $7.23(0.10)$ & N.S. \\
\hline Lowest bloodsugar, mmol// & $2.3(0.7)$ & $2.8(0.7)$ & $<0.025$ \\
\hline Temperature, ${ }^{\circ} \mathrm{C}$ & $35.5(0.7)$ & $36.1(0.4)$ & $<0.005$ \\
\hline Cap. haematocrit, \% & $68.5(10.5)$ & $64.7(6.3)$ & N.S. \\
\hline
\end{tabular}

\section{Discussion}

Using a P.I. below the $3 \mathrm{xd}$ percentile for gestational age as a cut-off point about half of the S.G.A. Infants in this study were disproportionally grown. This agrees well with the figure of 60 \% presented by Davies et al. (2) studying a group of infants with a birthweight below the 5 th percentile for gestational age. In our atudy the mean $P$.I. of the proportionally grown infants is well below the 50th percentile and ilke Davies et al. (2) we are of the opinion that S.G.A. infants are mainly disproportionally grown. However, this may apply only to well nourished mothers in view of the study of Woods et al. (10) who demonstrated that in a South African population of undernourished mothers proportionally grown S.G.A. infants prevailed.

Miller and Hassanein (6) demonstrated that birthweight for gestational age alone falls to reflect the nutritional status of many newborns at birth and that the P.I. needs to be used as an additional yardstick. Using this classification our study provides evidence that disproportionally grown S.G.A. infants are at 
a higher risk for neonatal complications than their proportionally grown counterparts: asphyxia, hypoglycemia, hypothermia, and hyperviscosity occurred more frequently in the alsproportionate group. Despite early intervention the overall inclidence of asphyxia in both groups was high in comparison with the flgure of $0.5 \%$ in a large group of term infants presented by MacDonald et a1. (11).

Probably due to the early feeding of the infants the overall incidence of hypoglycemia (98) was much lower than the figure of $25 \%$ reported in S.G.A. Infants in the early seventies (12, 13$)$. In the whole group hyperviscosity (188) occurred in about the same percentage as in the reports of Hakanson and oh (14) and Wirth et al. (B) about S.G.A. infants, but the incidence in the disproportionate group (308) was much higher. This may be correlated with the fact that intrauterine asphyxia was more often assoclated with disproportionate growth (15). As those infants showing hyperviscosity were treated by a plasma exchange transfusion (16) and as they probably have an advanced stage of functional liver maturity due to their larger blood volume (17), the incidence of hyperbilirubinemia was low.

Though placental insufficiency occurred more often in the group of disproportionally grown S.G.A. infants in this study, the origin of intrauterine growth retardation in both study groups often remained unknown. Extensive studies (18) have bhown that primary failure of placental function is found in only a relatively small proportion of placentae from deprived fetuses. As the mean placental weights in both groups of infants are equally low, a deflicient supply of oxygen or nutrients to the placenta seems a more attractive explanation. Possibly the high incidence of smoking during pregnancy is also of great importance as smoking has a direct toxic effect on the fetus (19). 


\section{References}

1. Gruenwald P. Pathology of the deprived fetus and its supply 1ine. In: Elliott $K$, Knight J, eds. Size at birth. Ciba Fan Symp 27. Amsteram: Elsevier, 1974; 3-26.

2. Davies DP, P1atts P, Pritchard JM, Wilkinson PW. Nutritional status of light-for-date infants at birth and its influence on early pogtnatal growth. Arch Dis Child 1979; 54:703-06.

3. Kloosterman GJ. On intraterine growth, the significance of prenatal care. Int J Gymecol Obstet 1970; 8: 895-912.

4. Tanner JM, Thomsom AM. Standards for birthweight at gestation periods from 32 to 42 weeks, allowing for maternal height and weight. Arch Dis Child 1970, 45: 566-69.

5. Roord JJ, Ramaekers LHJ. Quantification of intraterine malnutrition. Biol Neonate 1978; 33: 273-77.

6. Miller HC, Hassanein K. Diagnosis of impaired fetal growth in newborn infants. Pediatrics $1971 ; 48: 511-22$.

7. Dubowitz LMS, Dubowitz $V$, Golaberg $\mathrm{CL}$. Clinical assessment of gestational age in the newborn infant. I Pediatr 1970; 77: $1-10$.

8. Wirth FH, Goldberg KE, Luchenco LO. Neonatal hyperviscosity, I Incidence. Pediatrics 1979; 63: 833-36.

9. Hulsjes HJ, Aarnoudse JG. Arterlal or venous umbilical pH as a measure of neonatal morbidity. Early Hum Dev 1979; 3: $155-61$.

10. Woods DL, Malan AF, de $V$ Heese $\mathrm{A}$. Patterns of retarded fetal growth. Early Hum Dev 1979; 3: 257-62.

11. MacDonald HM, Mulligan JC, Allen AC, Taylor PM. Neonatal asphyxia, I Relationship of obstetric and neonatal complications to neonatal mortality in 38,405 consecutive deliveries. J Pediatr $1980 ; 96: 898-902$.

12. Lubchenco LO, Bard $\mathrm{H}$. Incidence of hypoglycaemia in newborn infants classified by bixth weight and gestational age. 
Pediatrics $1971 ; 47: 831-38$ *

13. de Leeuw $R$, de Vries IJ. Hypoglycaemia in small-for-dates newborn infants. Pediatrics $1976 ; 58: 18-22$.

14. Hakanson $D O$, On $W$. Hyperviscosity in the small-for-gestational age infant. Biol Neonate 1980; 37; 109-12.

15. Linderkamp 0 , Versmold HT, Messow-Zahn $K$, Muller-Holve W, Riegel KP, Betke $K$. The effect of intra-partum and intrauterine asphyxia on placental transfusion in premature and ful1-term infants. Eur J Pediatr 1978; 127:91-99.

16. Mackintosh TF, Walker CHM. Blood viscosity in the newborn. Arch Dis Child 1973; 48:547-53.

17. Burckhard $v$ Stockhausen $H$, struve $M$. Investigation of accelerated metabolic function in small for gestational age infants. Eur J Pediatr 1979; 132: 169-77.

18. Fox H. The histopathology of placental insufficlenty. I Clin Path 1976; 29, suppl 10: 1-8.

19. Naeye RL. Effects of maternal cigarette smoking on the fetua and placenta. Br J Obstet Gynaecol 1978; 85: 732-37. 


\section{Summary}

A group of term newborns affected by disproportionate intrauterine growth retardation as expressed by a small ponderal (100 $x$ $\mathrm{W} / \mathrm{L}^{3}$ ), was followed-up with appropriate normally grown controls matched for age, sex, birth rank and socilal class. Despite catch-up growth during the first six months after birth the study group was still underweight-for-length with lower mean skinfold measures at the age of 3 years in comparison with the controls. This indicates that, despite its late onset in pregnancy, disproportionate intrauterine growth retardation continues to influence growth in early childhood.

\section{Introduction}

Several authors $(1,2,3)$ have pointed out that intrauterine growth retardation (IUGR) cannot be diagnosed from birthweight and gestational age alone as these do not reflect the rates of growth in individual cases: some infants attain their birthweight by uniform glow growth, whereas others have experienced growth retardation in late pregnancy only. Unless there is some pathological or genetic condition within the fetus to account for its sow fetal growth rate, its cause must be considered to be an insufficient supply line (2). Clinically these infants can be divided into several types depending on the relative growth of the head and body length to the rest of the organs of the body $(1,2,4,5,6)$. Whereas with adequate fetal growth weight, length 
and head circumference are appropriate for gestational age, in mild and short-lived growth retardation only weight will be reduced due to loss of subcutaneous adipose tissue and muscle tissue (wasting). If weight and length are small bui head circumference is appropriate moderate, prolonged fetal growth retardation exists. A reduction of weight, length and head circumference suggests severe, prolonged growth retardation. So small-forgestational age (S.G.A.) infants are far from homogeneous in their physical appearance at birth. Even being born appropriatefor-gestational age (A.G.A.) does not necessarily indicate an optimal intrauterine growth rate as some A.G.A. infants have (1ike many S.G.A. infants) signs of recent weight loas (3).

It will be clear that a more rellable method of assessing fetal growth at birth is needed. A weight-for-length ratio eliminates the problem caused by large variations in length and weight within the group of S.G.A. infants when mearuring relative body weight. Several authors have proposed Rohrer's ponderal index (100 $\mathrm{x}$ weight in grams/length ${ }^{3}$ in $\left.\mathrm{cm}\right)$ to that purpose $(1,2,5)$. This index assesses whether an infant appears relatively 'fat" or 'thin' by quantification of the dissociation of weight and length. Infants who are small with respect to weight and length tend to have proportionate growth and their ponderal index is (near) normal. They experienced moderate or severe prolonged intrauterine growth retardation and their growth pattern has been described as chronic fetal distress (2), type 1 IUGR $(4,5)$ or proportionate IUGR $(6,7)$. Infants who are small with reapect to weight only are disproportionally grown and their small ponderal. index points to them being leaner, due in major part to less body fat as indicated by diminished skinfolds $(3,8)$ and due to a lesser muscle bulk (9). They experienced mild IUGR in the last few weeks of pregnancy only and have been described as subacute fetal distress (2), type II IUGR (4,5), and disproportionate IUGR (7). 
So by using the ponderal index an impression can be obtained about the duration and severity of IUGR, although this clinical classification is by no means infallible as there is or will be a conslderable overlap both in the clinical picture and also in the etiology of the types of IUGR. At least the use of the ponderal index attempts to bring some order into the diagnosis of IUGR so that different studies will be able to define exactly what type of infant is considered (5).

Recently Davies et al. (10) demonstrated significantly higher growth rate: (weight, length and head circumference) in severely wasted infants (ponderal index \& $3 \mathrm{rd}$ percentile) than in less wated infants (ponderal index $>10$ th percentile) during the first 3 months after birth. As it is not known how this type of intrauterine malnutrition (I.U.M.) affects growth in early chilahood, a group of disproportionally grown S.G.A. infants was followed-up from birth till the age of 3 years.

\section{Material and Methods}

25 Consecutively born S.G.A. infants (birthweight below the 10th percentile for gestational age of the kloosterman curves (11)) who showed clinically evident wasting, had a ponderal index below the 5 th percentile of Miller and Hassanein (1) and were free from fetal diseases (congenital infections, congenital anomalies, and chromosomal aberrations), where prospectively studied. 25 Healthy normally grown infants (birthweight between the loth and the goth percentiles for gestational age (11) and ponderal index well aboven the loth percentile (1)) acted as controls. All infants were Caucasian singletons born at a gestational age between 38 and 42 weeks, as verified by the Dubowitz score (12).

The two groups were carefully matched for place of delivery, duration of admission to the hospital, feeding practice when leaving the wards (breast feeding or formula feeding), gesta- 
tional age, sex (each group consisted of 12 girls and 13 boys), birth rank, social class and age at follow-up. The infants were drawn from 2 previous studies in which we established highly significant correlations between ponderal index and skinfold thickness (8) and between ponderal index and skeletal retardation (13). Using methods previously described $(8,13)$ welight, length, head circumference, and skinfold thickness were measured after birth. At the age of 3 months $( \pm 1$ week), 6 months ( \pm 1 week), 9 months ( \pm 1 week), 12 months ( \pm 2 weeks), 18 months ( \pm 2 weeks), 24 months ( \pm 2 weeks) and 30 months ( \pm 2 weeks) weight and length measurements were repeated. At a mean age of 38 (\$3) months (range 31-42 months) head circumference, triceps and subscapular skinfolds were estimated in combination with measurements of weight and length. Skinfolds were measured with a Holtain caliper and the techniques described by Tanner and Whitehouse (14).

For both groups means and standard deviations of weight, length, and ponderal index values were calculated at all indicated points of time. By means of a two-stage Bayesian model (15) mean growth velocity curves were constructed using all available weight, length, and (calculated) ponderal index values. These curves were converted into curves expressing the difference in weight (in $\mathrm{kg} /$ month), length (in $\mathrm{cm} /$ month) and ponderal index growth velocities between both groups (I.U.M. group minus controls) and their $95 \%$ confidence bands. Using the head circumference values obtained at birth and at re-assessment the mean head circumference growth in $\mathrm{cm}$ per month over the period was calculated for each group. The skinfold measurements at three year of age were compared with the standard values for British children provided by Tanner and Whitehouse (14). In all instances means and standard deviations with $p$ values were determined by unpaired two-tailed t-tests: 
Results

Table $l$ provides data about the clinical course of the pregnancies concerned, table 2 presents the mean values for gestational age, weight, length, head circumference, ponderal index, and abdominal skinfold thickness at birth in both groups of Infants as well as the mean (measured) height of their parents the parents were not weighed, so their ponderal index could not

Table 1 Data on the clinical course of the pregnancies:

\begin{tabular}{lll}
\hline Parameter & $\begin{array}{l}\text { I.U.M. } \\
\text { infants } \\
n=25\end{array}$ & $\begin{array}{l}\text { Controls } \\
n=25\end{array}$ \\
\hline Primigravidae & 17 & 17 \\
Toxemia & 14 & 2 \\
Smoking & 12 & 11 \\
IUGR $>36$ weeks of gestation & 21 & 0 \\
IUGR not diagnosed & 4 & 0 \\
Artiticial delivery & 0 & 0 \\
\hline
\end{tabular}

Table 2 Mean values of growth parameters at birth

\begin{tabular}{|c|c|c|c|}
\hline Parameter: & $\begin{array}{l}\text { L.U.M. infaullts } \\
\text { (SD) }\end{array}$ & $\begin{array}{l}\text { Controls } \\
\text { (SD) }\end{array}$ & $p$ \\
\hline Gestational age. weeks & $34.5(1.3)$ & $39.7(0.2)$ & NS \\
\hline Weight, $\mathrm{kg}$ & $2.37(0.23)$ & $3.43(0.40)$ & $<0,001$ \\
\hline Lenglh, con & $48.3 \cdot 11.59$ & $50.8(1.8)$ & $<0.000$ \\
\hline Head circumference, $\mathrm{cm}$ & $33.111 .3)$ & $34.5 \because 1.0)$ & $<0.001$ \\
\hline Ponderal index & $2.13 \cdot 10.10)$ & $3.61(0.15)$ & $<0.001$ \\
\hline Abdom. skinfold, mrn & $2.3(0.4)$ & 3.710 .61 & $<0,001$ \\
\hline Height mothers, cm & 16369.29 & 16518.7 & NSS \\
\hline Height fathers. cm & $173(7.5)$ & $175(9.3)$ & NS \\
\hline
\end{tabular}

be calculated). Though the I.U.M. Infants are clearly underweight-for-length, their mean length and head circumference values are also smaller in comparison with the controls. Till 6 months of age the I.U.M. infants show a significant greater welght growth velocity than the controls (fig. 1). Despite the above average rate of weight growth the mean weight growth curve of the I.U.M. group remains permanently bellow the loth percentile of the mational weight growth curve (16) (fig. 2). 13 out of 25 I.U.M. Infants and 2 out of 25 controls had a weight below the national loth percentile at the age of 3 years. 


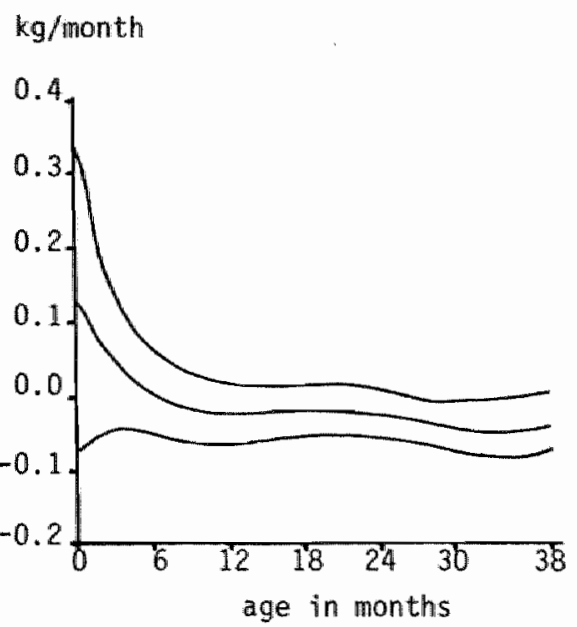

Flg. 1 Difference in mean weight growth velocities. The centre Iine expresses the difference in weight growth velocity (I.U.M. group minus controls) for chronological age. expressed as $\mathrm{kg} /$ month. The exterior lines constitute the 95 . confidence bands.

The length growth velocity of the I.U.M. group is slightly greater during the first 12 months after birth than that of the controls (fig. 3). At 12 months of age the group of I.U.M. infants crosses the loth percentile of the national length growth curve (16), (fig. 4). Ultimately 9 out of 25 I.U.M. infanta and 3 out of 25 controls remained below the national 10 th percentile.

In comparison with the controls the mean ponderal index curve of the I.U.M. group rises quickly after birth due to the initially greater weight growth velocity (fig. 5). From 9 tild 18 months the meari ponderal index af both groups are comparable, whereafter the mean ponderal index of the I.U.M. group lags behind as their weight gain is overshadowed by their gain in length. At the age of 3 years the I.U.M. group is still underweight for length (table 3), but the differences in length and head circumference between I.U.M. Infants and control have grown much smaller than 
at birth. The mean head circumference growth velocity over the 3-year period arnounted to $0.43 \mathrm{~cm} /$ month for the I.U.M. group and $0.41 \mathrm{~cm} /$ month for the controls, but the difference is not statistLcally signiflcant. 4 out of 25 I.U.M. Infants had a head circumference below the 5 th percentile of Nellhaus/(17) versus none of the controls at the age of 3 years.

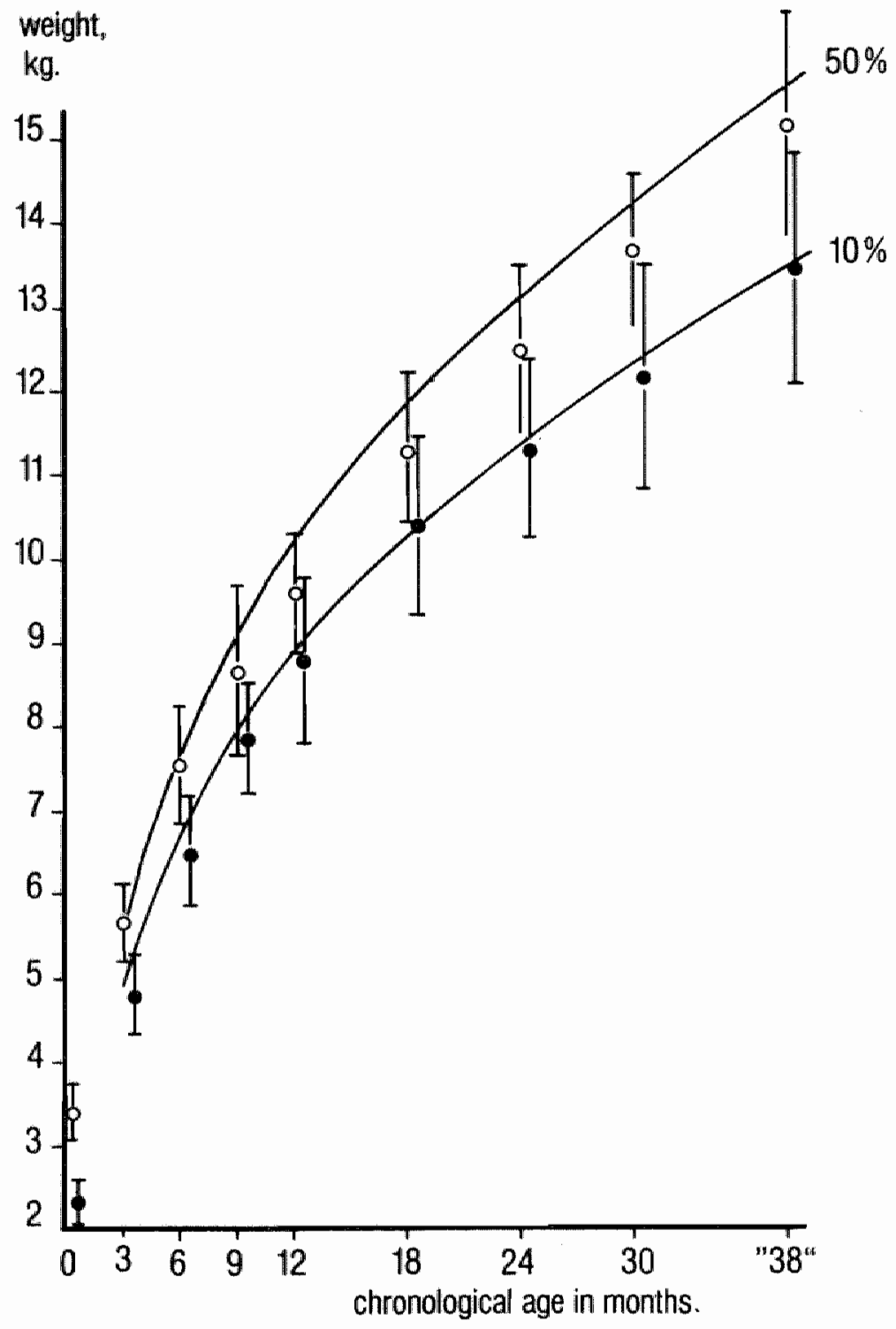

Fig. 2 Mean welght growth curves, in comparison with national standards (16). 0, controla: -, I.U.M. infants. 


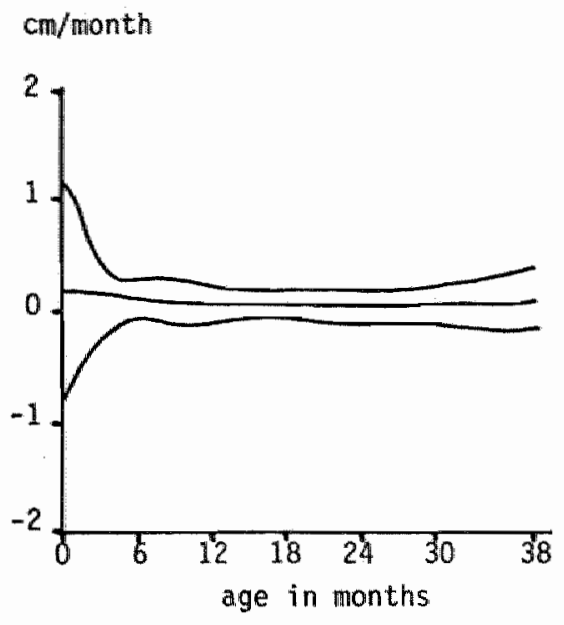

Fig. 3 Difference in mean length growth velocities. The centre line expresses the difference in length growth velocity (I.U.M. group minus contrals) for chronological age, expressed as $\mathrm{cm} /$ month. The exterior lines constitute the 95 confidence bands.

At the age of 3 years the mean triceps and subscapular skinfolds of the controls compare well with the 50th percentiles for British children of Tanner and Whitehouse (14), while the skinfolds of the I.U.M. infants remain well below these standards. The differences between the 2 groups are highly significant (p 40.001 , table 3 ) and regemble the situation at birth (table 2).

Table 3 Mean values of parameters at 3 years of age

\begin{tabular}{|c|c|c|c|}
\hline Patramelars & $\begin{array}{l}\text { 1.U. M. infonts } \\
\text { GSD }\end{array}$ & $\begin{array}{l}\text { Controls } \\
\text { SDi }\end{array}$ & $p$ \\
\hline Age, months & $37.9(3.4)$ & $37.9(3.4)$ & $\mathbb{N 5}$ \\
\hline Wenhth $6 \mathrm{gg}$ & $13.5(11.4)$ & $15.2(1.3)$ & $<0.001$ \\
\hline Length, cm & $95.3(3.7)$ & $97,3 \cdot 4,0)$ & $<0.05$ \\
\hline Heafl circumference. crit & $49.1(1.8)$ & $50.2(10.0)$ & $<0.05$ \\
\hline Ponderat index & $1.50(0.141$ & $(.6,5,10.14)$ & $<0.05$ \\
\hline Triceps skinfold. mn & $9.6(1.1)$ & $11,1(1,3)$ & $<0.60$ \\
\hline Subscapular skinfold mm & $5.9(0.6)$ & $6.7(0.5)$ & $<0.001$ \\
\hline
\end{tabular}




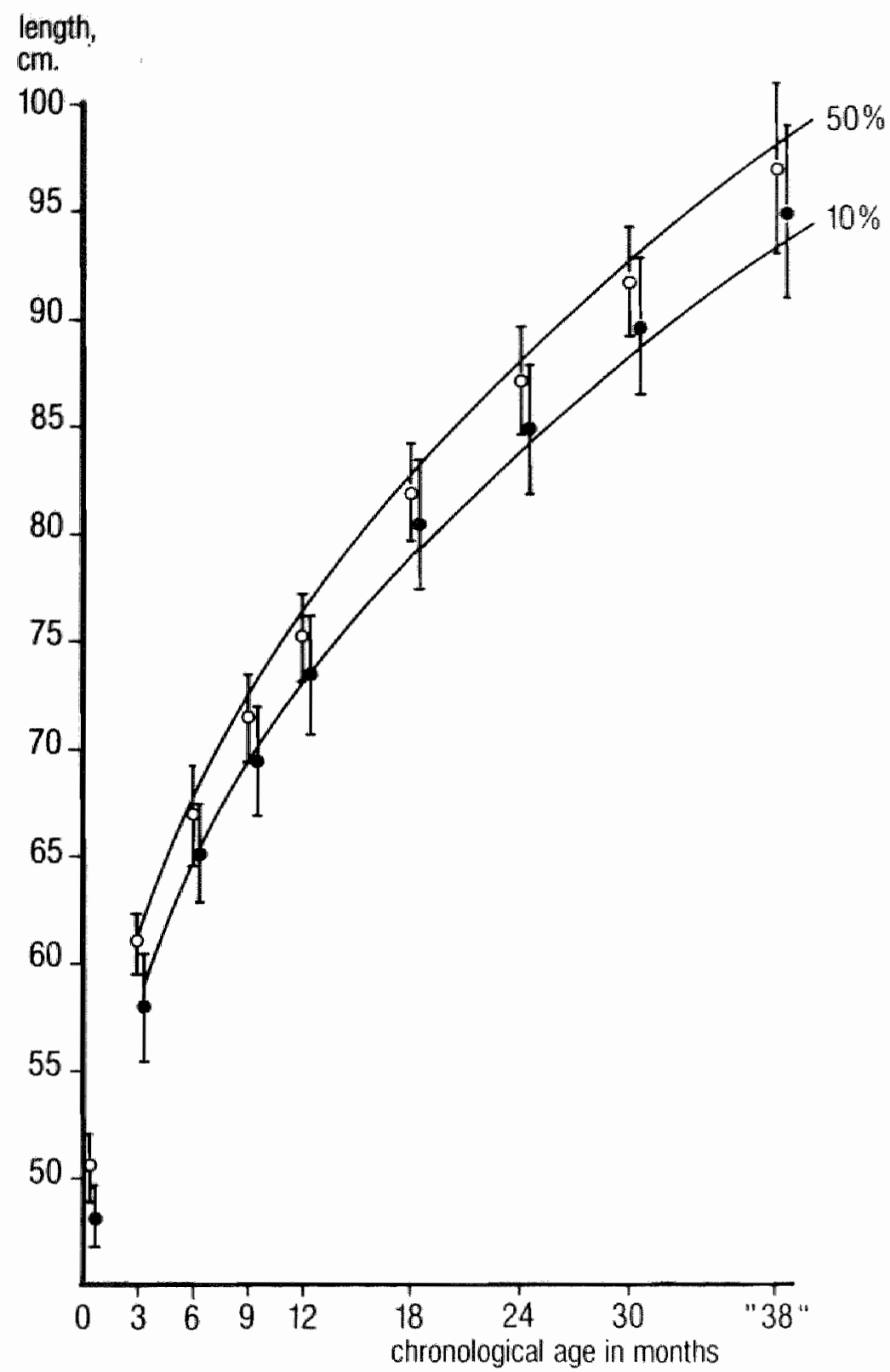

Fig. 4 Mean length growth curves, in comparison with national standards (16). O, controls; *, I.U.M. infants * 


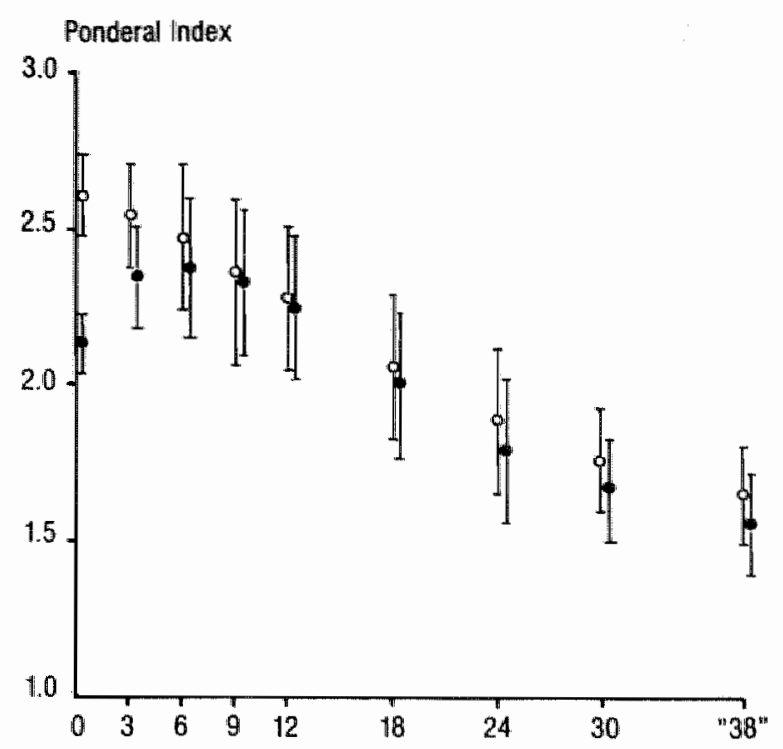

Chronological agein months

Fig. 5 Mean ponderal index values from 0 till 3 years of age. o, controls; :, I.U.M. Infants.

\section{Discussion}

Despite the presence of postnatal catch-up growth the infants who showed disproportionate intrauterine growth retardation at birth (the I.U.M. group) continued to be underweight-for-length and lean at the age of 3 years. The upward shift in length and head circumference is greater than that for welght. However, when disproportionally grown infants are considered individually there is still a considerable divergity in growth proflles, a stuation common within populations of S.G.A. Infants (18).

Though a Bubgroup of S.G.A. Infants was studied, the resulta of this study compare well with those of authors (18-22) who followed-up S.G.A. Infanta defined by birthwelght for gestational age only and who established that S.G.A. infants are lighter, maller and have a smaller head circumference at pre-school age. Chamberlain et al. $(20,21)$ remarked that S.G.A. Infants were 
relatively underweight-for-length at 22 and 42 months of age but did not quantify this by using a weight-length ratio, like e.g. the ponderal index.

Davies et al. (10) showed that in the first 3 months after blith disproportionally grown term S.G.A. Infants (with a ponderal index below the $3 r d$ percentile) gain more rapidiy in weight, length and head circumference than more proportionally grown term S.G.A. infants (with a ponderal index between the loth and 50 th percentiles) whereas in both groups rates of growth in each of the 3 months after birth were greater than in normal term infants.

This study partially confirms the findings of Davies et al. (10), but also shows that the catch-up growth in disproportionate intrauterine growth retardation is not complete at the age of 3 years. In fact disproportionate intrauterine growth retardation leads to a growth pattern resembling that of the whole group of S.G.A. infants in early childhood. Possibly this is due to the presence of many disproportionally grown infants in the groups of S.G.A. infants studied. A most interesting finding is the development of the ponderal index in the two groups. At birth the difference is large, at 12 months of age the difference is very ama11, but at the age of 3 years the difference is again statistlcally ignificant. The change from birth till the age of 12 months has also been reported by Davies and Beverly (23), but the picture at $2-3$ years of age is an unknown feature. Nutritional habits of both groups did not differ widely and eating problems were equally common (24). Though matching of social class was done t birth, the distribution of the social class hardy changed in the ensuing years. However, the I.U.M. infants turned out to be more often hyperactive than the control at the age of $3(24,25)$ and this may be the reason why their mean weight gain was retarded resulting in a low ponderal index. 
Gruenwald (2) supposed that intrauterine growth retardation in the later weeks of pregnancy (i.e. disproportlonate growth) would result in complete catch-up growth after birth. This study denles this postulation and provides evidence that even intrauterine growth retardation of short duration may have longterm adverse effects upon later phyilical growth. Further follow-up studies are necessary to establish the ultimate growth potential of infants affected by disproportionate growth retardation.

\section{References}

1. Miller HC, Hassanein K. Diagnosis of limpaired fetal growth in newborn infants. Pediatrics 1971, 48: 511-22.

2. Gruenwald P. Pathology of the deprived fetus and its supply line. In: Elliott $K$, Knight $J$, eds. Size at birth. Ciba Fan Symp 27 (new series). Amsterdam: E1sevier, 1974: 3-26.

3. Usher RH. clinical and therapeutic aspects of fetal malnutrition. Pediatr C1in North Am 1970; 17: 169-83.

4. Urrust1 J, Yoshida P, Velasco L et al. Human fetal growth retardation: $I$. Clinical features of sample with intrauterine growth retardation. Pediatrics 1971; 50:547-58.

5. Rosso P, Winick M. Intrauterine growth retardation. A new syatematic approach based on the clinical and biochemical characteristics of this condition. J Perinat Med 1974, 2: $147-60$

6. Woods DL, Malan AF, Heese H de V. Patterns of retarded fetal growth. Early Hum Dev 1979: 3: 257-62.

7. Renfleld ML. The small-for-date infant. In: Avery GB, ed. Neonatology, pathophysiology and management of the newborn. Philadelphia: Lippincott, 1975: 189-201.

8. Roord JJ, Ramaekers LHJ. Quantiflication of intrauterine malnutrition. Biol Neonate 1978; 33: 273-77. 
9. Widdowson EM, Crabb DE, Milner RDG. Cellular development of some organs before birth. Arch Dis Child 1972; 47:652-59.

10. Davies DP, Platts P, Pritchard JM, Wilkinson PW. Nutritional status of light-for-date infants at birth and its influence on early postnatal growth. Arch Dis Child 1979; 54: 703-06.

11. Kloosterman GJ. On intrauterine growth, the significance of prenatal care. Int. I Gynaecol Obstetr 1970; 8: 895-912.

12. Dubowitz LMS, Dubowitz $V$, Goldberg $C$. Clinical assessment of gestational age in the newborn infant. J Pediatr 1970:77: $1-10$.

13. Roord JJ, Ramaekers LHJ, Van Engelshoven JMA. Intrauterine malnutrition and skeletal retardation. Biol Neonate 1978; 34 : $167-69$.

14. Tanner JM, Whitehouse RH. Revised standards for triceps and subscapular skinfolds in British children. Arch Dis Child $1975 ; 50: 142-45$.

15. Lindley DV, Smith AFM. Bayes estimates for the linear model. J R S S (B) $1972 ; 34: 1-41$.

16. Wieringen JC van, Wafelbakker $F$, Verbrugge HP, De Haas JH. Groeidiagrammen Nederland 1965. Ned. Instituut $v$ Preventieve Geneeskunde Two Leiden. Groningen: "Woltters-Wororaror, "Nob.

17. Nellhaus $G$. Head circumference from birth to elghteen years. Pediatrics $1968 ; 41: 106-14$.

18. Fitzhardinge $\mathrm{PM}$, Steven $\mathrm{EM}$. The sma11-for-date infant. I. Later growth patterns. Pediatrics $1972 ; 49: 671-81$.

19. Babson SG. Growth of low-bixth-weight infants. I pediatr $1970 ; 77: 11-18$.

20. Chamberiain $\mathbb{R}$, Davey $\mathbb{A}$. Physical growth in twins, postmature and small-for-dates children. Arch Dis Child 1975; 50: 43742 . 
21. Chamberlain RN, Simpson RN. Cross-sectional studies of physical growth in twins, postmature and small-for-dates children. Acta Paediatr Scand 1977; 66: 457-63.

22. Martell M, Falkner $F$, Bertolini LB et al. Early postnatal growth evaluation in full term, preterm and small-for-dates infants. Early Hum Dev 1978; 1: 457-63.

23. Davies DP, Bewerly D. Changes in body proportions over the first year of 1 ife: comparisons between 'light-for-dates' and 'appropriate-for-dates' term infants. Early Hum Dev 1979: 3: $263-65$.

24. Walther FJ, Ramaekers LHJ. Developmental aspects of aubacute fetal distress: Behaviour problems and neurological dysfunction. Early Hum Dev 1982; 6: 1-10.

25. Walther FJ, Ramaekers LHJ. Language development at the age of 3 years of infants malnourished in utero. Neuropediatrics $1982 ; 13: 77-81$. 


\section{PUBLICATION V: SKELETAL MATURITY AT BIRTH AND AT THE AGE OF 3 YEARS OF INFANTS MALNOURISHED IN UTERO}

\section{Summary}

Twenty-five term infants malnourished in utero and 25 matched controls were studied at birth and at $2 \frac{1}{2}-3 \frac{1}{2}$ years of age. At birth the infants malnourished in utero had a significant retardation in skeletal maturity in comparison with the control group. At $2 \frac{1}{2}-3 \frac{1}{2}$ years of age the average skeletal maturity of the intrauterine malnourished children approached that of the controls. However, those with a length below the national loth centlle still showed a retarded skeletal growth in comparison with those who had reached a length above the loth centile for age.

\section{Introduction}

One of the characteristics of infants malnourished in utero (I.U.M.) is the fact that their skeletal maturity at birth is retarded (6). Ualing the ponderal index as a measure of the nutritional atate of these infants at birth, Roord et al. (4) etablished close relation between ponderal index $\left(100 \mathrm{x} / \mathrm{L}^{3}\right)$ and akeletal maturity at birth.

The ultimate catch-up of akeletal maturity in I.U.M. infants 13 unknown in the long term, however. As part of a prospective study we investigated 25 I.U.M. Infants and 25 controls, matched

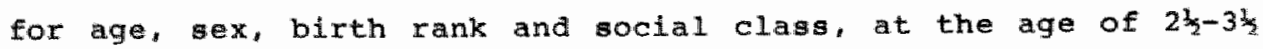
years (average 3 years and 2 months) in order to see whether the retarded skeletal maturity diagnosed at birth among the I.U.M. group caught up during the first years of life. 


\section{Methods}

Thirty one term I.U.M. Infants (4) were studied at birth in comparison with 25 normally grown term infants, adnitted to the neonatal ward. All were Caucasian singletons born at a gestational age between 38 and 42 weeks, verified by the Dubowitz score. Intrauterine malnutrition was defined as: (1) clinically evident wasting: (2) ponderal index $\left(100 \times w / L^{3}\right)$ on or below the 10th centile of Lubchenco et al. (3): and (3) absence of signs of congenital malformation, congenttal infection and chronosoma malformation. Weight and length were recorded at birth and the ponderal index calculated. Skeletal maturity was determined within 2 days after birth by means of an anterior-posterior X-ray film of the knee and a lateral film of the foot (4). The maturity standards of Russel1 (5) based on amenorrhoea in weeks were used.

At $2 \frac{1}{2}-3 \frac{1}{2}$ years of age 25 of the 31 I.U.M. children (4 had moved to other regions; 2 families did not assent to re-investigation) were extensively assessed for growth, behaviour, neurology and language development. As the original 25 controls were all born after artificial deliveriea, it was necessary to define a new group of 25 controls from healthy attenders of local child health clinics without perinatal problems or chronic diseases. These new controls were matched for age, sex, birth rank and social class. Weight and height were measured in all children and the ponderall index calculated. By means of an anterior-posterfor $X-r a y$ of the left hand and wrist skeletal maturity in months of age was established using the Tw2 rating system described by Tanner and Whitehouse (8).

\section{Results}

Mean values and standard deviations for weight, length, ponderal index and skeletal maturity at birth are presented in table 1 . 


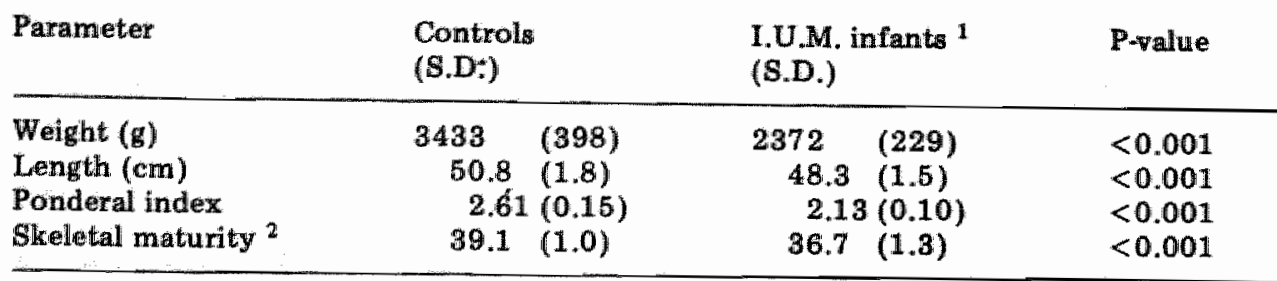

1 Figures of the 25 I.U.M. infants re-investigated at $2 \frac{1}{2}-3 \frac{1}{2}$ years of age.

2 Expressed as amenorrhoea in weeks, mean amenorrhoea of controls was 39.7 weeks and of I.U.M. infants 39.5 weeks.

Table 2 Mean growth parameters at $2 \frac{1}{2}-3 \frac{1}{2}$ years (average 37.9 montha) of age

\begin{tabular}{lccl} 
Parameter & $\begin{array}{l}\text { Controls } \\
\text { (S.D.) }\end{array}$ & $\begin{array}{l}\text { I.U.M. infants } \\
\text { (S.D.) }\end{array}$ & P-value \\
\hline Weight (kg) & $15.2(1.3)$ & $13.5(1.4)$ & $<0.001$ \\
Length (cm) & $97.3(4.0)$ & $95.3(3.7)$ & N.S. \\
Ponderal index & $1.65(0.14)$ & $1.56(0.14)$ & $<0.05$ \\
Skeletal maturity 1 & $37.1(4.3)$ & $36.2(5.4)$ & N.S. \\
\hline
\end{tabular}

1 Expressed as bone "age' in months of age.

N.S., not significant.

The figurea obtained at $2 \frac{k}{2}-3 \frac{t}{2}$ years of age are shown in table 2 * statistical analysis was done by using paired t-tests.

Figures 1 and 2 show the actual measurements of skeletal maturity at birth in relation to gestational age and at 2 by -3 ly years of age in relation to age in months, respectively.

Tables 1 and 2 , as well as figures 1 and 2 clearly show that at the age of 3 years the significant differences in skeletal maturity between the I.U.M. children and normal controls, established at birth, have disappeared. Though the mean ponderal index value at birth and at 3 years of age are lower in the I.U.M. group, no correlation between ponderal index and skeletal maturIty at follow-up could be established despite the firm relation between these two at birth $(x=0.67, p<0.001)$ (4). Nine children of the I.U.M. group had a length at follow-up below the national loth centile for age (9). Their mean age was 39.7 months, but their mean skeletal maturity only 34.4 months. The 16 
skeletal maturity

in weeks of gestation

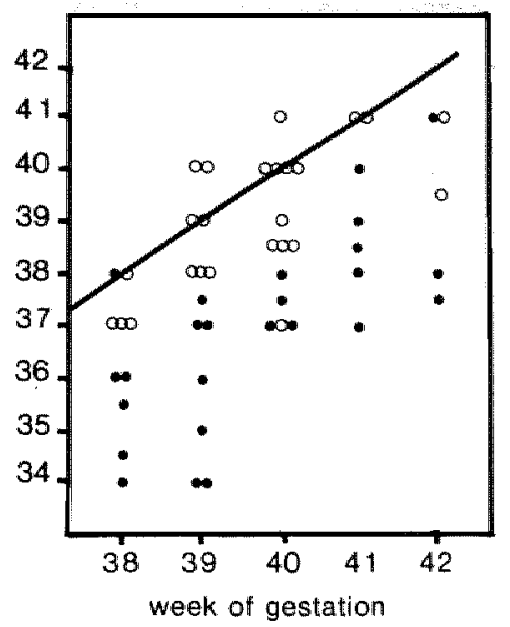

Figure 1 skeletal maturity at birth in relation with gestational age. o, controls; -. I.U.M. infants.

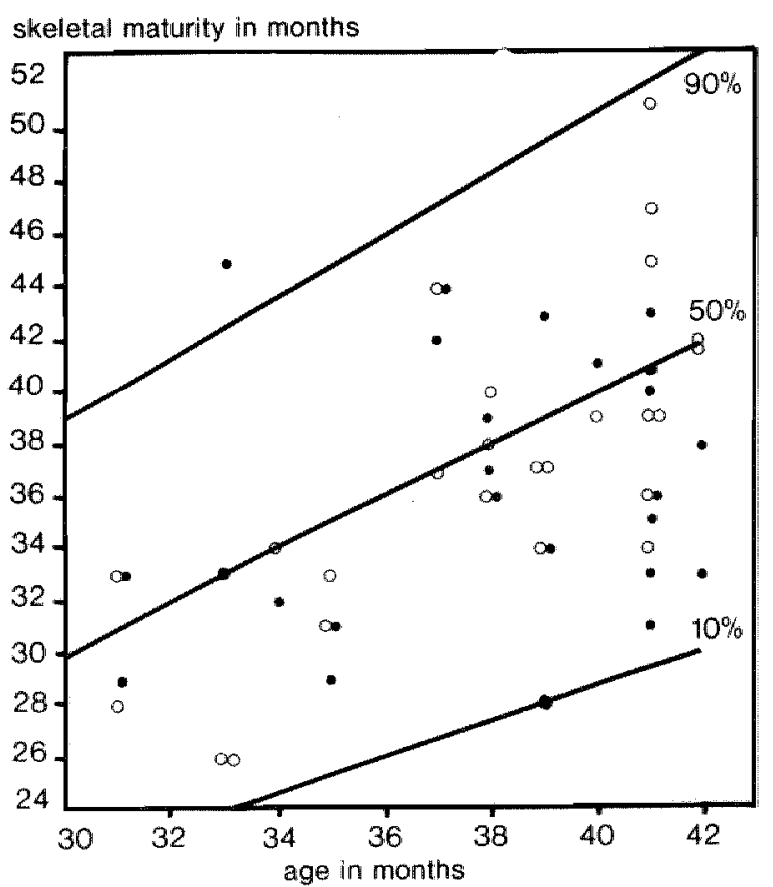

Figure 2 skeletal maturity at $2 \frac{1}{2}-3 \frac{1}{2}$ years of age (average 3 years and 2 months) in relation with chronological age. o. controls; •, I.U.M. infants. 
I.U.M. children with a length above the loth centile for age had a mean age of 36.9 months and mean skeletal maturity of 37.2 months. Mis difference of 5 months was statistically significant $(p<0.025)$.

\section{Discussion}

At birth the duration and severity of the adverse fetal environment is reflected by the degree of skeletal growth retardation (4). In the ensuing months and years physical recovery takes place. In this study chilaren previously malnourished in utero show lower mean values for weight, length and ponderal index at the age of 3 years In comparison with matched controls, but the differences are becoming smaller than at birth. This same finding applies to skeletal maturity. Only those with a length below the national loth centile of length for age show retarded skeletal growth, which implies a relation between length and skeletal maturity. This fact was also reported by Fitzhardinge and steven (1) studying S.G.A. chilaren after the age of 4 years. They used the Greulich-pyle atlas (2) for the estimation of skeletal maturity which represents more rapidly maturing children than that of Tanner and Whitehouse ( 8 ).

Tannex et al. (7) showed a high correlation between height at 3 years of age and adult height, which would imply that about one third of the intrauterine malnourished children will grow up into relatively mall adults. This is difficult to understand as these children mostly have a retarded skeletal maturity at 3 years of age, which might be a sign that they have a greater potential for prolonged linear growth.

Further study of these chllaren is necessary. Also it will be necessary to determine the time when, between 0 and 3 years of age, I.U.M. children start to catch-up in skeletal maturity. A study by our group is being conducted to answer this question. 


\section{References}

1. Fitzhardinge $P M$ and Steven EM (1972): The small-for-date infant. I. Later growth patterns. Pediatrios, 49,671-681.

2. Greulich WW and Pyle SI (1959): Radiographic atlas of skeletal development of hand and wrist. 2nd Edn. Stanford University Press, California.

3. Lubchenco Lo, Hansmann $C$ and Boyd $E$ (1966): Intrauterine growth in length and head circumference as estimated from live births at gestational ages from 26 to 42 weeks. Peaiatrics, 37, 403-408.

4. Roord JJ, Ramaekers IHJ and Van Engelshoven JMA (1978): Intrauterine malnutrition and skeletal retardation. Biol Neonate, 34, 167-169.

5. Russel1 JGB (1973): Radiology in obstetrics and antenatal paediatrics * Butterworth, London.

6. Scott KE and Usher R (1964): Epiphyseal development in fetal malnutrition syndrome. New Engl J Med, 270, 822-824.

7. Tanner JM, Healy MJR, Lockhart RD, Mackenzie JD and Whitehouse $\mathbb{R H}$ (1958): The prediction of adult body measurem ments from measurements taken each year from birth to five years. Arch Dis Child, 31, 372-381.

8. Tanner JM, Whitehouse RH, Marshall WA, HealY MJR and Goldstein H $(1975)$ : Assessment of skeletal maturlty and prediction of adult height (TW 2 method). Academic Press, Londen.

9. Van wieringen JC (1.972): Secular changes of growth, 1964-1966 height and weight surveys in The Netherlands in hilatorical perspective. Nederlands Instituut $v$ Praeventileve Geneeskunde TNO, Leiden. 


\section{PUBLICATION VI: DEVELOPMENTAL ASPECTS OF SUBACUTE FETAL DISTRESS: BEHAVIOUR PROBLEMS AND NEUROLOGICAL DYSFUNCTION}

\section{Summary}

A group of term linfants malnourished in utero and classified as subacute fetal distress at birth were followed up with a group of normally grown term infants matched for age, sex, birth rank and social clabs. Both groups were free from other perinatal morbidity and chronic diseases. At three years of age behaviour was atudied using the behaviour screening questionnaire of Richman and Graham and a behaviour observation report, whereas neurological dysfunction was assessed according to the proforma of Touwen. Both problematic behaviour and neurological dysfunction accurred more frequently in the subacute fetal distress group. Behaviour problems are comparable to neurological signs as indicators for brain dysfunction.

\section{Introduction}

Gruenwald (6) firgt called attention to the fact that the weight of most organs of small-for-gestational age (S.G.A.) infants are reduced. While the liver, spleen, adrenals and thymus are severe$1 y$ reduced in size, brain and pancreas appear to be the least affected. The human brain initiates the period of rapid weight gain during the last half of fetal life, with a peak near the time of birth which then decreases over the first year of postnatal ife (3).

There are two major periods of brain cell multiplication: one (the neuroblasts), from 15 to 20 weeks of gestation and one (the glia) which commences at about 25 weeks of gestation. This second 
period probable ends in the second year after birth (2). Approximately two-thirds of the human brain cells, as represented by DNA, accumulate prior to birth (20). The 'brain growth spurt' may be a period of enhanced vulnerability to nutritional restriction (3). Timing in relation to birth, severity and duration of intrauterine growth retardation will determine the final growth limitation of the brain. In guinea pigs (who, like humans, initiate the brain growth spurt in utero) adequate postnatal nutrition offsets some, though not all of the biochemical changes resulting from intrauterine growth retaraation (1). Thomas et al. (16) demonstrated by means of stereological analysis of the brains of rats undernourished from birth (within the brain growth spurt) a deficit in the synapse to neuron ratio. The question arises whether the brain changes produced by intrauterine growth retardation are functionaliy important and reversible during the period of nutritional rehabilitation after birth. At school age problematic behaviour is more frequently encountered in S.G.A. Infants than amongst infants without perinatal morbidity (10). Richman et al. (13) showed that cne rate of behaviour problems at three years of age is very similar to that in later childhood and early adolescence. Early detection of behaviour problems is therefore possible but well-defined criteria have to be used as most behaviour problems at preschool age consist of exaggeration or inappropriate prolongation of normal behaviour patterns. The behaviour screening questionnaire (BSQ) developed by Richman and Graham (12) is a valid screening tool in this field (13), epectally if substantiated by observation of the child's behavlour. Behaviour is a complex function of the nervous system, dyfunction of this system can be further substantiated by neurological assessment. A proper tool therefore is the examination proforma for minor neurological dysfunction of Touwen (17). This consists of an observation of the child"s motor behaviour and the 
testing of specific nervous functions.

Using behaviour and neurological examination as parameter we asessed at the age of 3 years the outcome of a group of term Infants who were malnourished in utero and were classifled as subacute fetal distress due to their disproportional growth at birth. According to Gruenwald (7) the growth retardation in theme infanta started a few werk before birth, they appeared wasted at birth due to loss of subcutaneous adipose tissue and loose skinfolds (14). In earlifer studles we reported about their physical growth $(18,19)$.

\section{Subjects and Methods}

25 Term infants showing disproportlonal growth and a subnormal nutritional state at birth (subacute fetal distress) were prospectively studied in comparison with 25 normally grown term infants of both sexes and from all social classes. All were Caucasian singleton born at gestational age of between 38 and 42 weeks, as verified by the Dubowitz acore (4).

The study group was drawn from 2 previous studies in which we established highly significant correlations between ponderal index (weight in grams $x$ 100/length ${ }^{3}$ in $\mathrm{cm}^{\prime} \mathrm{s}$ ) and skinfold thicknes (14) as well as skeletal retardation (15). Selected were those infant who: 1) showed elinically evident wasting, 2) had a ponderal index on or below the loth centile of Lubchenco et al. (9). 3) were free from fetal diseases (congenital infections and anomalies, chromogomal aberrations) and 4) did not have further perinatal complicationsl such as artificial delivery asphyia, hypothermia, hyperbilirubinemia, hypoglycaemia and hyperviscosity). All had a birthweight on or below the loth centile of the Kloosterman curves (B).

The control group consisted of infants with a ponderal index above the 25th centile (9), a birthweight well above the 10 th 
centlie (8) and an uneventful perinatal perlod. The two groups were matched for age, sex, birth rank and social class. All children were free from chronic and/or debilitating diseases from birth onwards. In none of the families severe relational or parental problems were present and all families were representative for their social class.

At a mean age of 3 years and 2 months (range 31-42 months) behaviour and neurology were assessed. The behaviour screening questionnaire (BSQ) was completed by the first author in a short interview with the mother (sometimes accompanied by the father). The 12 items of the behaviour scale were taken from the 60 questions dealing with the current health, development and behaviour of the child as described by Richman and Graham (12). The items of problem behaviour concerned: 1) eating, 2) sleeping, 3) soiling, 4) activity, 5) concentration, 6) relations witn other children, 7) attention seeking and dependency, 8) difficulty to manage, 9) tempers, 10) mood, 11) worries and 12) fears. A 3point rating scale was used: a score of 0 indicates that the problem behaviour is absent, a score of 1 that it is sometimes present or present to a mild degree and a score of 2 that it occurs frequently or to a marked degree. Activity could only be scored as 0 (normal) and 2 (hyperactive). The score of each child was summed, a score of 10 or more points interpreted as showing moderate to severe behaviour problems (13). All items were also analysed seperately.

As parental reports on specific items of behaviour might be inaccurate all children were also clinically assessed in the presence of the parent(s) by a second examiner (T.K.) to avolid bias. A behaviour observation report (BOR) was used, consisting of 8 items: 1) activity, 2) concentration, 3) attention seeking and dependency, 4) negativism, 5) insistency, 6) destructivity and aggression, 7) fidgetiness and 8) fears. These items were 
formulated according to the lines used in the BSQ and again a 3 -point score was used. A sumed score of 7 or more lusing the same $40 \%$ cut-off point as in the BSO) was interpreted as the pregence of moderate to severe behaviour problems auring observation.

Meurologlcal dysfunction was studied using the 26 items sultable for chilaren of 3 years of age of the examination proforma for minor neurological dysfunction of Touwen (17). A score of o meant an optimal and a sore of 1 a suboptimal performance for chronological age of the item by the individual chila. The items tested are presented in table 4. Summed scores were calculated and all 1tems were also analysed separately.

The atudy was carried out blindly, none of the examiners knew the history or former examination results of the children. Statistical analyses were performed by means of the $x^{2}$-test.

\section{Results}

To provide a picture of the children in this study, some perinatal figures are presented in table 1 (see also reference 19).

Using the summed BSQ scores the differences between the two groups just falled to reach statistical significance $\left(\mathrm{X}^{2}=3.323\right.$, DF 4). The controls had a mean summed BSO score of 6.1 (s.d. 3.6) and the subacute fetal distress group of 7.6 (s.d. 4.1).

Table 1 Mean parameters at birth of the subacute fetal distres group and the controls (see ref. 19)

\begin{tabular}{lccc}
\hline & $\begin{array}{l}\text { Subacute fetal } \\
\text { distress group } \\
\text { (S.D.) }\end{array}$ & $\begin{array}{l}\text { Controls } \\
\text { (S.D.) }\end{array}$ & P \\
\hline Birthweight (kg) & $2.37(0.23)$ & $3.43(0.40)$ & $<0.001$ \\
Ponderal index & $2.13(0.10)$ & $2.61(0.15)$ & $<0.001$ \\
Gestational age (wks) & $39.5(1.3)$ & $39.7(1.2)$ & n.s. \\
Present age (mth) & $37.9(3.4)$ & $37.9(3.4)$ & n.s. \\
\hline
\end{tabular}

n.s. not significant. 
Cell frequency counts of controls and subacute fetal

distress children in the behaviour screening questionnaire $(B S Q)$

\begin{tabular}{|c|c|c|c|c|c|c|c|c|c|}
\hline \multirow[t]{2}{*}{ Itemis BSQ } & \multicolumn{3}{|c|}{$\begin{array}{l}\text { Subacute fetal distress group } \\
(n=25)\end{array}$} & \multicolumn{3}{|c|}{ Controls $(n=25 \mathrm{j}$} & \multicolumn{3}{|c|}{ Staivitios } \\
\hline & score $=0$ & seore $=1$ & seore $=2$ & score $=0$ & scost $=1$ & $\operatorname{sen} x=2$ & $x^{2}$ & $\mathrm{DF}$ & $\tilde{\mathbf{p}}$ \\
\hline Eating & 18 & 4 & 3 & 14 & 9 & 2 & 2.676 & 2 & nositio \\
\hline Sheeping & 20 & 3 & 2 & 19 & 1 & 5 & 2.400 & 2 & n.s. \\
\hline Soilling & 18 & 0 & 7 & 23 & 0 & 2 & 3.593 & 1 & $<0.09$ \\
\hline Activity & 7 & $a$ & 18 & 13 & 0 & 12 & 3.030 & 1 & $<0,04$ \\
\hline Concentration & 8 & 4 & 13 & 10 & 9 & 6 & 4.837 & 2 & $<0.05$ \\
\hline Rellations & 17 & 1 & 7 & 19 & 0 & 6 & 1.574 & 2 & $\mathrm{n}, \mathrm{s}_{\mathrm{n}}$ \\
\hline \multicolumn{10}{|l|}{ Attention } \\
\hline serking/dependency & 19 & 1 & $s$ & 14 & 4 & 7 & 3.023 & 2 & as $s$ \\
\hline Difficulty to managc & 12 & 4 & 9 & 10 & 6 & 9 & 0.585 & 2 & mis. \\
\hline Tempers & 11 & 4 & 10 & 12 & 7 & 6 & 1.883 & 2 & as.s. \\
\hline Mood & 23 & 1 & 1 & 22 & 3 & 0 & 2.455 & 2 & m.s. \\
\hline Worries & 21 & 2 & 2. & 24 & 0 & 1 & $3.3 \mathrm{I}$ & 2 & n.s.s. \\
\hline Fears & is & $\$$ & 2 & 24 & 0 & 1 & 13.526 & 2 & $<0,0000$ \\
\hline Total & 189 & 32 & 79 & 204 & 39 & 57 & 4.821 & 2 & $<0,05$ \\
\hline
\end{tabular}

Table 3 Cell frequency counts of controls and subacute fetal distress children in the behaviour observation report (BOR)

\begin{tabular}{|c|c|c|c|c|c|c|c|c|c|}
\hline \multirow[t]{2}{*}{ Itterns BOR } & \multicolumn{3}{|c|}{$\begin{array}{l}\text { Subacute fetal distress group } \\
(n=2 S) \text {. }\end{array}$} & \multicolumn{3}{|c|}{ Conirols $(n=25)$} & \multicolumn{3}{|c|}{ Statistics } \\
\hline & score $=0$ & score $=1$ & score $=2$ & score $=0$ & scone $=1$ & score $=2$ & $x^{2}$ & DF & 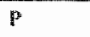 \\
\hline Actiwity & 7 & 1 & 17 & 13 & 5 & 7 & 9.030 & 2 & $<0.006$ \\
\hline Concentration & 9 & 2 & 14 & 1.5 & 5 & 5 & 7.283 & 2 & $<0.01$ \\
\hline \multicolumn{10}{|l|}{ Atkention } \\
\hline seeking / dependency & 17 & 1 & 7 & 17 & 3 & $s$ & $1.3 \$ 1$ & 2 & n.s. \\
\hline Negatiwisim & 16 & 3 & 6 & 19) & 2 & 4 & 0.862 & 2 & n.s.s. \\
\hline Insistency & 19 & 0 & 6 & 21 & 0 & 4 & 0.125 & 1 & nest \\
\hline Destruetiwily/aggression & 20 & 0 & 5 & 22 & 0 & 3 & 0.149 & 1 & ns: \\
\hline Fidgetiness & 21 & 0 & 4 & 23 & 0 & 2 & 0.189 & I & n.s. \\
\hline Fienars & 13 & 3 & 9 & 24 & 0 & $!$ & 14.840 & 2 & $<0,0003$ \\
\hline Total & 122 & 10 & 68 & 15.4 & is & 31 & 16538 & 2 & $* 0.0122$ \\
\hline
\end{tabular}

However, 4 of the 12 items of the $B S Q$ were more frequentiy encountered in the group of subacute fetal diftress children. The were solling, hyperactivity, concentration disorders and fears (table 2 ).

The summed BOR scores showed that behaviour problems were significantly more common in the subacute fetal distres group (mean score 5.8 and s.d. 3.2) than in the controls (mean score 3.1 and s.d. 2.6), $\left(\mathrm{x}^{2}=11.800, \mathrm{DF}=5, \mathrm{p}<0.02\right)$. Table 3 demonstrates that in this assessment also hyperactivity, concentration disorders and fears occurred more often in the subacute 
fetal distress group. A firm linterrelationship could be established between the summed $B S Q$ and $B O R$ scores $\left(X^{2}=18.706, D F=\right.$ 6. $p(0.005)$

Table 4 Cell frequency counts of controls and subacute fetal diatress children in the neurological assessment

\begin{tabular}{|c|c|c|c|c|c|c|c|}
\hline \multirow[t]{2}{*}{ 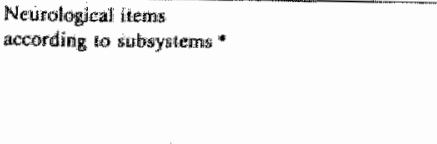 } & \multicolumn{2}{|c|}{$\begin{array}{l}\text { Subacale fetal } \\
\text { thisthess group } \\
(n-295\end{array}$} & \multicolumn{2}{|l|}{$\begin{array}{l}\text { Continots } \\
\{\text { a : } 25,\}\end{array}$} & \multicolumn{3}{|c|}{ Statistita } \\
\hline & $\operatorname{score}=0$ & $\sec 0 \cos =1$ & $\operatorname{scor}=0$ & $\operatorname{scofic}:=1$ & $x^{2}$ & $\mathrm{DF}$ & p \\
\hline \multicolumn{8}{|l|}{ 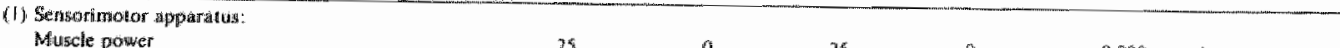 } \\
\hline Mulscite power & 25 & 0 & 25 & 0 & 0000 & 1 & n.s. \\
\hline 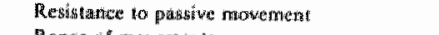 & 24 & 1 & 25 & i) & 1020 & 1 & ns \\
\hline Ramger of ripowernents & 22 & 3 & 25 & 0 & . 3.1911 & I. & $<0.104$ \\
\hline Tondon refkes & 23 & 2 & 25 & d & 2083 & 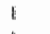 & 月1.5. \\
\hline 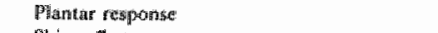 & 19 & 6 & 22 & $y$ & 1.319 & i & W. \\
\hline Skin reflexed & 24 & $\mathbb{i}$ & 25 & $\theta$ & 1.020 & 1 & $n . s$ \\
\hline \multicolumn{8}{|l|}{ (2) Pótiure: } \\
\hline Situnding pererat & 14 & III & $2 !$ & 4 & 4.667 & 1 & $<0.02$ \\
\hline Extendod arms. standing & 18 & 7 & 20 & 5 & $0.63 \mathrm{x}$ & 1 & M.s. \\
\hline Willing & 19 & 6 & 19 & B & 0,00 & 1 & s.s. \\
\hline Cufitist & 14 & $\|$ & 20 & 5 & 3.309 & 1 & $<0.04$ \\
\hline Inspection of the buck /spine & 23 & 2 & $x_{4}$ & 1 & 0.355 & 1 & $\mathrm{n}$ \\
\hline Lying in prone/stiphio posingen & 23 & 2 & 24 & 1 & 0.355 & 1 & 较.5 \\
\hline \multicolumn{8}{|l|}{$\begin{array}{l}\text { (3) Gross molor lifaclions: } \\
\text { Wralking on fuptowe }\end{array}$} \\
\hline Wralking on tiphose & 24 & 1 & 24 & 1 & 0.000 & 1 & ns.s. \\
\hline Watking on healsi & 18 & 7 & 21 & 4 & 1.049 & 1 & $\mathrm{~ns}$ \\
\hline Sianding on one leg & 23 & 2 & 25 & 0 & $20 k 3$ & 1 & n.s. \\
\hline Hopping oq one leg & 28 & 0 & $2 s$ & ) & 0.090 & 1 & a.s. \\
\hline \multicolumn{8}{|l|}{ (d) Coordination of the extremities: } \\
\hline 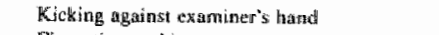 & 24 & I & 25 & 1) & 1.020 & 1 & n.s. \\
\hline Fingerip toxuchiag test & 21 & 4 & 25 & 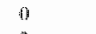 & 4,348 & $\sharp$ & $<000$ \\
\hline Sranding with ayes elosed & 1 13 & 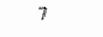 & 22 & 3 & 2.000 & 1 & n.s. \\
\hline \multicolumn{8}{|l|}{ (S) Q wality of anotilety: } \\
\hline Sitting fspeed, sriwoothness, adecluary of & 14 & I甘 & 23) & 2 & 8420 & 1 & $<0,02$ \\
\hline 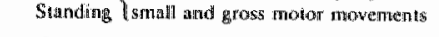 & 16 & 9 & 21 & ut & 2590 & 1 & ต.s. \\
\hline \multicolumn{8}{|l|}{ (6) (Dys) kinesiat } \\
\hline Ghloretiform rowernemes & 20 & 5 & 25 & 0 & 5555 & 目 & $<0.0$ \\
\hline Alutentic movitimentis & 24 & 1 & 25 & 0 & 1.1720 & $\|$ & ก.ร. \\
\hline \multicolumn{8}{|l|}{ (7) Vinual systean: } \\
\hline Position and egre andwetinh & 25 & 0 & 25 & 0 & $a(A)$ & 1 & fies. \\
\hline 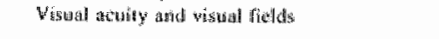 & 24 & 目 & 25 & u & $1,112 i)$ & 1 & 的. 8 \\
\hline \multicolumn{8}{|l|}{9 Mrotitifng: } \\
\hline 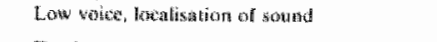 & 25 & 0 & 29 & ) & 0.00 & i & n.:. \\
\hline Total & 540 & 101 & 611 & 39 & 30.74 & : & $=0.0901$ \\
\hline
\end{tabular}

"Adapted frown Totanem [1?]

At the neurological examination no major neurological defects like cerebral and epilepsia were diagnosed (table 4). The controls presented a mean score of 1.6 (s.d. 1.5) and the subacute fetal distress group of 4.0 (s.d. 2.1). This difference was statistically significant $\left(\mathrm{X}^{2}=21.765, \mathrm{DF}=9, \mathrm{p}(0.005)\right.$. 6 Of the 26 neurological items showed significant differences to the detriment of the subacute fetal distress group: range of move- 
ments, standing posture, gait, fingertip touchlng test, quallty of motility sitting, and choreiform movements. Hearing and vision (one child used epectacles) were never appreciably affected.

Problematic behaviour and neurological dysfunction turned out to be firmly interrelated. The sumed neurological scores correlated well with the summed $\mathrm{BSO}$ scores $\left(\mathrm{X}^{2}=9.040\right.$, DF $=2$, $\mathrm{p}$ * $0.025)$ and the summed $B O R$ scores $\left(X^{2}=12.430, D F=3, p(0.01)\right.$.

Table 5 Incidence of problematic behavilour and neurological dysfunctions in both groups

\begin{tabular}{|c|c|c|c|}
\hline & \multicolumn{2}{|c|}{ Problematic behaviour } & \multirow[t]{2}{*}{ Neurollogical dysfunction } \\
\hline & $\mathrm{BSQ}$ & $\mathrm{BOR}$ & \\
\hline Subarute fetal distress group & $8 / 25$ & $8 / 25$ & $9 / 25$ \\
\hline Camtrols & $4 / 25$ & $2 / 25$ & $1 / 25$ \\
\hline Torall & $12, / 50$ & $10 / 50$ & $10 / 50$ \\
\hline
\end{tabular}

Individual scores are presented in table 5, the cut-off point of the BSQ score was 10 or more points, of the BOR score 7 or more points and of the neurological score 5 or more (the mean score of the control group plus 2 standard deviations). 2 Children of the control group scored high in the BSQ (both scores = 10). whereas their behaviour during the observation turned out to be normal (BOR scores of both children = 5).

\section{Discussion}

The behaviour screening questionnaire (BSQ) is able to select out 100\% children with moderate to severe behaviour problems but only Just over a third of those with mild behaviour problems (13). Richman et al. (13) reported that using a cut-off score of 10 points on the BSQ there are about 6 false positives (1.... children assigned to the group of problematic behaviour who on clinical assessment have no or a dubious behaviour problem) and about 10 false negatives (1.e*, children in the group of normal. 
behaviour who on clinical assessment appear to have a mild behavLour problem).

A combination of BSQ with clinical observation (BOR) i therefore more valuable than the BSO alone. In this way 2 out of 25 controls were found to have a moderate to severe behaviour problem, an inclaence comparable to the figure of approximately 7 of a ample of 705 chilaren living in a London borough obtained by Richman and co-workers (13). The incidence of problematic behavLour among the subacute fetal distress infants (8 out of 25) 1 s therefore really high. Our findings compare well with those of Neligan et al. (10) for term controls and S.G.A. Infants at 5-7 years of age, In spite of the fact that subacute fetal distress accounte only for a (probably large) subgroup of the S.G.A. population. Hyperactivity and concentration disorders on one side and exaggerated fears on the other alde are two characteristic patterng of behaviour of these children which emerged from our study.

The overall neurological plcture is clearly different among both groups and as none of the children had significant vision and hearing disorders, the 9 (out of 25) subacute fetal distress Infanta and the 1 (out of 25) child of the contral group can be realiatically be classifled as showing neurological dysfunction. Fitzhardinge and steven (5), atudying term S.G.A. Infants at 4-6 year of age, established a low Incldence of major neurological defecta (and then especially among those who had sustalined severe neonatal asphyxil) and a high incidence (about 25\%) of 'minimal brain dyafunction'. Almost the same picture emerges from the study of Neligan et al. (10) among term S.G.a. infants at the age of 5-7 years. Though we assessed a subgroup of S.G.A. infants (subacute fetal distress) at a younger age with a different investigation scheme, our result are comparable with these two stuales $(5,10)$. 
As both neurological dysfunction and behaviour problems reflect a brain dysfunction. it is not amaing to find the interrelationship between these assessments. The cause of the brain dysfunction in the subacute fetal distress infants is most probably related to the intrauterine malnutrition which they experienced as this was the only variable parameter between the two groups in the study which were also carefully matched to rule out environmental factors as good as possible.

Precht1 (11), realizing that brain lesions are not static and that brain development depends on innate capacities and personal/ environmental experience, suggests that if the brain becomes damaged rewiring may occur to a considerable degree. This hypothesis may explain why only one-third of the children in the subacute fetal distress group showed behaviour problems and/or neurological dysfunction.

Concluding, this study shows that despite the relatively short duration of intrauterine malnutrition, subacute fetal alstress often results in signs of brain dysfunction at the age of 3 years. Behaviour problems are comparable to neurologlcal igns as indicators for brain dysfunction.

\section{References}

1. Chase HP, Dabiere CS, Welch NN and $0^{\prime B r i e n}$ D (1971): Intrauterine undernutrition and brain development. Pediatrics 47 . $491-500$

2. Dobbing $J$ and Sands $J(1970)$ : Tiling of neuroblast multiplication in developing human brain. Nature $226,639-640$.

3. Dobbing $J$ and Sands $J$ (1979): Comparative aspects of the brain growth spurt. Ear1y Hum Dev 3, 79-83.

4. Dubowitz LMS, Dubowitz $V$ and Goldberg $C$ (1970): C1inlcal assessment of gestational age in the newborn infant. J Pediatr $77,1-10$. 
5. Pitzardinge $\mathrm{EM}$ and steven EM (1972): The small-for-date infant. II Neurological and intellectual sequalae. Pediatrics $50,50-57$.

6. Gruenwald $P$ (1963): Chronic fetal distress and placental Ingufficlency. BLol Neonate 5, 225-265.

7. Gruenwald P (1974): Pathology of the deprived fetus and its supply line. In: Size at Birth. pp. 3-26. Editors: K Elliott and J Knight. Ciba Fan Symp 27 (new series). Excerpta Medica, Amsterdam.

8. Kloosterman GJ (1970): On intrauterine growth, the significance of prenatal care. Int J Gynaecol Obstetr 8, 895-912.

9. Lubchenco LO, Hansmamn $C$ and Boyd $E$ (1966): Intrauterine growth in length and head circumference as estimated from live births at gestational ages from 26 till 42 weeks. Pediatrics $37,403-408$.

10. Neligan GA, Kolvin I, Scott D MCI and Garside RE (1976): Born too soon or born too small. Clinics in Developmental Medicine no. 61. Spastics International publications. Heinemann, London.

11. Prechtl HFR (1978): Minimal brain dysfunction syndrome and the plasticity of the nervous system. Adv Biol Psych 1 , 96-105.

12. Richman $\mathbb{N}$ and Graham PJ (1971): A behavioural screening questionnalre for wise with three-year-old children. Preliminary findings. I Child Psychol Psych $12,5-33$.

13. Richman N, Stevenson JE and Graham PJ (1975): Prevalence of behaviour problems in 3-year-old children: an epidemiological atudy in a London borough. J Child Psychol Psych 16, 277-287.

14. Roord JJ and Ramakers LHJ (1978): Quantification of intrauterine malnutrition. Biol Neonate $33,273-277$.

15. Roord JJ, Ramaekers LHJ and Van Engelshoven JMA (1978): Intrauterine malnutrition and skeletal retardation. Biol 
Neonate $34,167-169$.

16. Thomas YM, Bedi KS, Davies CA and Dobbing J (1979): A stereological analysis of the neuronal and synaptic content of the frontal and cerebellar cortex of weanling rats undernouriahed from birth. Early Hum Dev 3, 109-126.

17. Touwen BCL (1979): Examination of the child with minor neurological dysfunction. 2nd Edition. Clinics in Developmental Medicine no. 71. Spastics International Medical Publications. Heinemann, London.

18. Walther FJ, Ramaekers LHJ and Van Engelshoven JMA (1981): skeletal maturity at birth and at the age of 3 years of infants malnourished in utero. Earty Hum Dev 5, 139-143.

19. Walther FJ and Ramaekers LHJ (1982): Growth in early childhood of newborns affected by disproportionate intrauterine growth retardation. Acta Paediatr Scand 71, 651-656.

20. Winick $M$ (1968): Changes in nucleic acid and protein content of the human brain during growth. Pediatr Res 2, 352-355. 


\section{PUBLICATION VII: LANGUAGE DEVELOPMENT AT THE AGE OF 3 YEARS OF INFANTS MALNOURISHED IN UTERO}

\section{Summary}

To evaluate if language testing might provide useful information about the developmental outcome at pre-school age of term infants malnourished in utero, a group of these infants was studied in combination with a group of normally grown term infants matched for age, sex, birth rank and social class. Both groups were free from significant neonatal morbidity and debilitating diseases. Intraterine malnutrition was defined as underweight for gestational age and the presence of wasting to belect those S.G.A. infants wth recognizable signs of malnutrition at birth. The Reyme11 Developmental Language Scales were used to test language and the results were related to a separate assessment of behavlour and neurology.

Both verbal comprehension and expressive language were significantly less developed in infants malnourished in utero. A fIrm relation was established between language delay and behavlour problems. It was concluded that language development can be used to asses the developmental progress of infant malnourished in utero 1 f performed in combination with behaviour assesment. Many of these infants will benefit by speech therapy during behaviour therapy at pre-school age.

\section{Introduction}

Animal and human studies have shown that nutritional restriction during the brain growth spurt leads to definite chemical and morphological changes of the brain lDobbing et al., 1979; Thomas et 1., 1979; Winick, 1969). In humans this vulnerable period 
starts during intrauterine life (Dobbing et al." 1979) and so intrauterine malnutrition may result into functional brain damage. This is partially reflected by the high incidence of school failures among small-for-gestational age (S.G.A.) infants (Neligan et al., 1976) despite the fact that their average Io scores are aften in the normal range (Babson et al., 1969; Fitzharainge et al., 1972).

Language may be one of the many possible expressions of brain dysfunction as a result of nutritional restriction during the brain growth spurt. As language develops quickly over the age range of 2 to 5 years and as it is dependent on the blological maturation of the brain (Rutter et al., 1972), it may be useful as a testable higher cerebral function at pre-school age. Fitzhardinge et a1. (1972) reported that S.G.A. infants frequently showed speech problems at the age of 3 to 4 years and had to be referred to a speech therapist.

To evaluate if language testing might provide useful information about their developmental outcome, we studied a group of term infants malnourished in utero and a group of matched normally grown controls at the age of 3 years. The Reynell Developmental Language Sicales (Reynel1, 1969 a) were used to test language development as these scales have a high sensitivity at 3 years of age. As language achievements may be influenced by behaviour and neurological dysfunction, the results are reluted to the outcome of a previous study of these same infants' behavioural and neurological development (walther et al., 1981).

The study group consisted of term infants with a birthweight below the 10 th national percentile (Kloosterman, 1970) and with clinically evident wasting due to a reduced quantity of subcutaneous adipose tissue (Roord et al., 1978 a). The degree of wasting at birth was quantified by the use of the ponderal. Index (100 $x$ weight/length ${ }^{3}$ ) according to MHLler et al. (1971). 
Gruenwald (1974), and Roord et al. (1978 a), who proposed the ponderal index as a measure of the nutritional state at birth. By using theae two parameters we selected infants who were underweight-for-geatational age and underweight-for-length. Gruenwald (1974) showed that the intrauterine growth retardation in these Infanta atarted only a few weeks before birth due to an insufficlent supply line (subacute fetal distress). In our opinion these infants are easily recognizable as presenting intrauterine malnutrition (I.U.M.) at birth.

\section{Subjects and Methods}

25 Consecutively born term infants showing intrauterine malnutrition were prospectively studied in comparison with 25 normally grow term infants. All were caucasian singletons born at a gestational age of between 38 and 42 weeks, as verifled by the Dubowitz score (Dubowitz et al., 1970).

The infants participated in two earlier studies in which we established highly significant correlations between ponderal index (weight in grams $\times 100 / 1 \mathrm{ength}^{3}$ in $\mathrm{cm}$ ) and skinfold thickness (Roord et al., 1978 a) as well as skeletal retardation (Roord et al., 1978 b). The underweight infants (1) showed clinically avident wasting, (2) had a ponderal index below the $5 \mathrm{th}$ percentile of Miller et al. (1971). (3) had a birthweight below the loth percentile of the Kloosterman grid (Kloosterman, 1970), and (4) were free from fetal diseases lcongenital infections and anomalies, chromosomal aberrations) and from significant neonatal morblidty. The control group consisted of healthy non-wasted infants who had a ponderal index and a birthweight well above the 10th percentile and an uneventful perinatal period. The two groups were exactly matched for age, sex (12 girls and 13 boys in each group), birth rank and social class. Hearing and vision were intact in all children, chronic diseases were absent and none of 
them was bilingual. In their families severe relational or parental problems were absent.

The children were assessed with the Experimental Edition of the Reynell Developmental Language scales at a mean age of 3 years and 2 months (range $31-42$ months). The R.D.L.S. (Reynell, 1969 a) consists of 3 scales: (1) The Verbal Comprehension scale A uses toys and requires no speech, some hand function is necessary as the child has to point out non-verbally that he understands the examiner, (2) The Verbal Comprehension scale $B$ is an adaptation of scale A for handicapped children without speech and hand function, nearly all responses can be performed by eyepointing, and (3) The Expressive Language Scale which is divided into three sections. The expressive language structure section taps the very earliest stages of pre-language, from the earllest vocalizations to the correct use of complex sentences with subordinate clauses. The expressive language vocabulary section assesses the child's ability to name simple objects, pictures, and actions as well as to describe words (and not so much his knowledge of them). In the expressive language content section the ability to verbalize connected thoughts is investigated: the child has to describe 5 different pictures without leading questions. As none of the children were known to be severely handicapped the verbal comprehension scale $A$ and the expresive language scale could be used. The verbal comprehension scale was carried out first as this requires no speech and provides sufficient relaxation to obtain appropriate responses to the expressive language scale from young children. Two experienced speech therapists performed the tests, the mother was always within reach to put the child at his ease.

The raw scores of the different test ltems were turned into developmental age scores according to the standardization sample (Reyne11, 1969 a). The significance of differences of mean values 
wa determined by the student paired two-tailed t-test.

\section{Results}

In Table $I$ the mean growth parameters at birth are presented to provide a plcture of the children admitted to this study. In general the group of infants malnourished in utero (I.U.M.) was more difficult to test than the group of controls. Testing often lasted longer due to marked hyperactivity and poorer concentration abilities of these chilaren. Most children fully completed both language scales, however.

Table I Mean growth parameters at birth

\begin{tabular}{|c|c|c|c|c|c|}
\hline \multirow[b]{2}{*}{ Birthwelghti, gh } & \multicolumn{2}{|c|}{ cantrols $(s . d)$} & \multicolumn{2}{|c|}{ 1. U. M. infants (s.d) } & \multirow{2}{*}{$\frac{p}{<0.001}$} \\
\hline & 3.433 & $(398)$ & 2,372 & $(229)$ & \\
\hline Length, cm & 50.8 & $(1.8)$ & 48.3 & $(1.5)$ & $<0.00 \|^{\circ}$ \\
\hline Head circumferenco, cm & 34.5 & $(1.0)$ & 33.1 & (1.3) & $<0.001^{c}$ \\
\hline Ponderal index & 2.64 & $(0.15)$ & 2.13 & $(0.10)$ & $<0.001^{\circ}$ \\
\hline Qestational age, wooks & 39.7 & $(1.2)$ & 39.5 & $(1.3)$ & N.S. \\
\hline
\end{tabular}

N. S.: not signiticant

$t=10.9154, D^{*} 24 \quad{ }^{t} t=7.2043$, DF $24 \quad c t=8.4913$, DF $24 \quad d t=14.2973$, DF 2.4

Table II Language assessment (R.D.L.S.), mean raw scores and developmental ages in months

\begin{tabular}{|c|c|c|c|c|c|c|c|c|}
\hline \multirow[b]{2}{*}{ Verbal comprehension } & \multicolumn{2}{|c|}{$\begin{array}{l}\text { Controls } \\
\text { (s.d.) } \\
\text { raw score }\end{array}$} & \multicolumn{2}{|c|}{ diex,age } & \multicolumn{2}{|c|}{$\begin{array}{l}\text { A. U. M. infants } \\
\text { (s. d) } \\
\text { raw scone }\end{array}$} & dev. age & \multirow{2}{*}{$\begin{array}{l}\mathrm{p} \\
<0.0 \mathrm{~s}^{\mathrm{a}}\end{array}$} \\
\hline & 41.0 & $(6.6)$ & 44.1 & $(6.6)$ & 37.3 & $(8.1)$ & $40.2 \quad(7.4)$ & \\
\hline 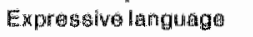 & 35.2 & $(9.3)$ & 35.9 & $(18.6)$ & 30.0 & $(12.2)$ & $310 \quad(10.7)$ & $<0.025$ \\
\hline structur: & 14.2 & (3.2) & 29.0 & $(90)$ & 13.6 & $(3.11)$ & $26.1(6.9)$ & $\mathbb{N} \cdot S_{i}$ \\
\hline wocabultury & 15.6 & (4.3) & 42.9 & $(120)$ & 12.2 & $(7,1)$ & $35.7 \quad(21.3)$ & $<0,03^{\circ}$ \\
\hline content & 5.4 & (3.8) & 30.0 & $(17.2)$ & 4.3 & $(3.5)$ & $24.1 \quad(17.5)$ & N.S. \\
\hline Mag an age & & & 37.9 & $(3.4)$ & & & $37.9(3.4)$ & M. S. \\
\hline
\end{tabular}

$t=2.1620, D F 24 \quad b t=2.4137, D F 24 \quad C_{t}=2.3579, D F 24$

The mean raw scores and corresponding mean developmental ages of the language assessment are presented in Table II. The achievements were worse for the I.U.M. children than for the controls. The differences amounted to 4 months for verbal comprehension and 5 months for expressive language and were statistically significant at the $5 \%$ level. Girls tended to score higher than boys on both scales (a common phenomenon), but the same differences between both groups were found in either sex. 
Table III Relation of language achievement to behaviour problems and neurological dysfunction

\begin{tabular}{llll}
\hline Language achievement & $\begin{array}{l}\text { Behaviour } \\
\text { problems }\end{array}$ & $\begin{array}{l}\text { Neurological } \\
\text { dysfunction }\end{array}$ \\
\hline Delayed & 2 controls & 0 & 0 \\
& 8I. U. M. infants & 6 & 4 \\
\hline & 23 controls & 2 & 1 \\
Adequate & 17 I. U. M. infants & 2 & 5 \\
\hline a see reference 24 & & \\
\hline
\end{tabular}

Figure 1 shows that many children were more advanced in verbal comprehension in comparison with the standard. Only one child lof the I.U.M. group) had a very low score, 1.e. more than 2 standard deviations below the standard mean for chronological age. Many

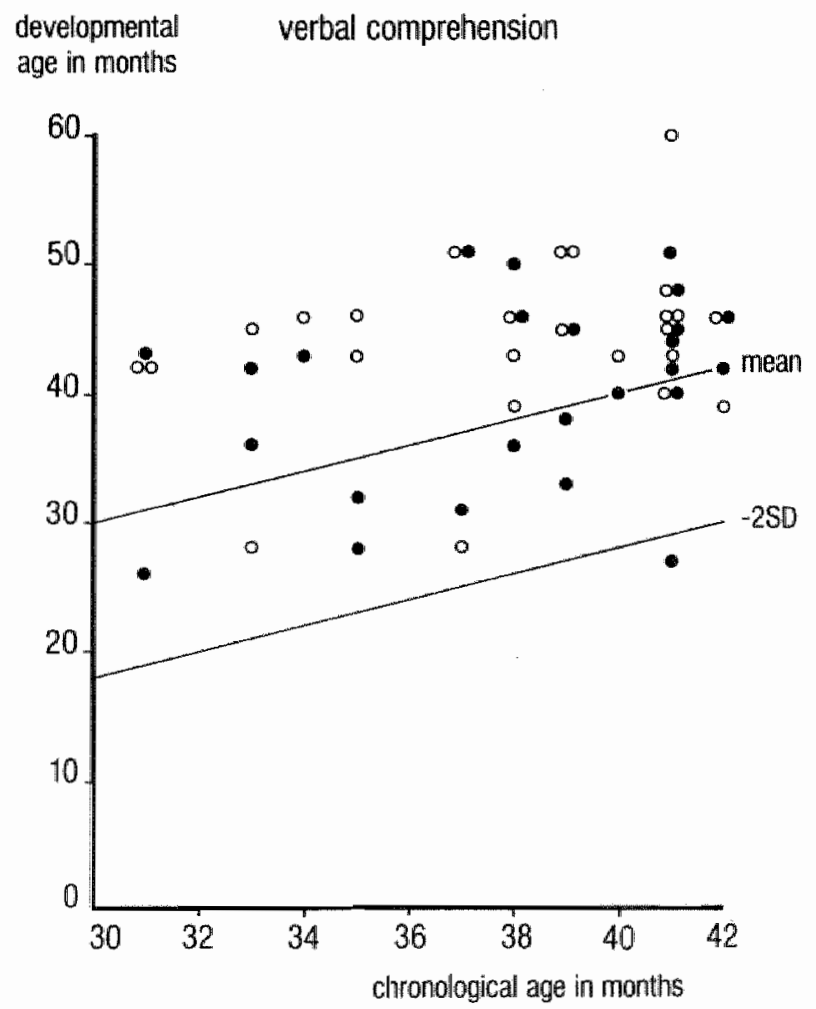

Figure 1 Verbal comprenension, developmental age in montha versus chronological age in months; $0=$ controls and $=I \cdot U \cdot M \cdot$ infants. 


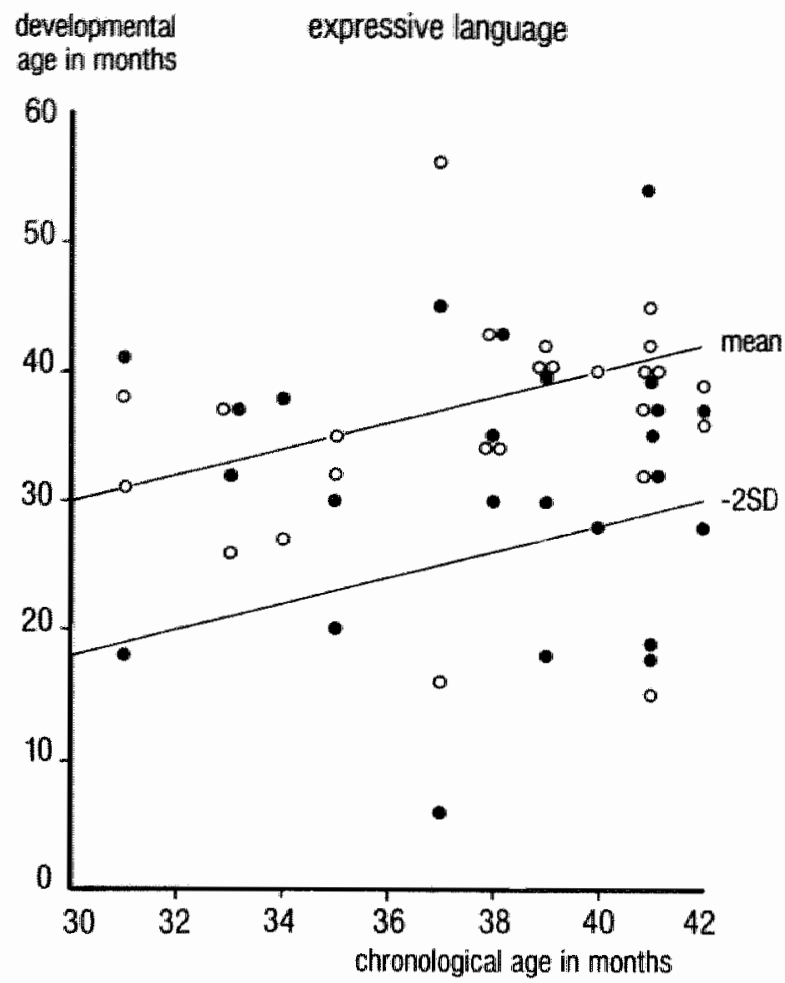

Figure 2 Expressive language, developmental age in months versus chronological age in months; $0=$ controls and $b=$ I.U.M. infants.

more children presented an expressive language delay (figure 2): 2 controls and 8 I.U.M. children scored 2 or more standard deviations below the standard mean. 6 of these 10 children were of lower ability in verbal comprehension as they scored more than one standard deviation below the mean. Of the three sections of expressive language only the vocabulary scores showed statistically significant differences to the detriment of the I.U.M. group with 1 control and 6 I.U.M. children scoring more than 2 standard deviations below the standard mean. As structure develops quicker than vocabulary and content is the last of the three expressive language sections to develop (Reynell, 1969 a) at the test age, the latter section provides too little information to 
be representative. Expressive language structure scores were relatively low in both groups but the mean walues were comparable.

Finally 2 (out of 25) controls and 8 (out of 25) I.U.M. children were classified as language retarded on the verbal comprehension and/or expressive language scales (with scores of 2 or more standard deviations below the standard mean). Using the criterion that language delay implies an achievement < 2/3 chronological age, the same chilaren were identified. The incldence of behaviour problems in I.U.M. Infants with language delay was high, whereas neurological dysfunction occurred to about the same extent in I.U.M. Infants with and without language dellay (Table III). The relation of language delay to behaviour problems is statistically highly significant $\left(x^{2}=12.5\right.$, DF $=1, p(0.0005)$.

\section{Discussion}

Ideally language assessment procedures measure verbal comprehension, expressive language, articulation, and intelifibility (Randall et al., 1974). The latter performance can only be rated subjectively and does not add much information as most children are easily intelligible at the age of 3 years (Randall et al.. 1974), therefore it was onitted in this study.

Initially we tried to investigate articulation by means of the "Utrecht articulation test" (Peddemors-Boon et a1., 1.977) for 3-6 year old children. But practice soon learned that the test was too extensive (106 items) and took too much time after the completion of the R.D.L.S. for these young children. As severe articulation defects will affect the structural aspects of expressive language (because the child uses short and incomplete sentences. Reyne11, 1969 b), without affecting the vocabulary and content sections, and as articulation difficulties are a poor indicator of the child"s true language development at the age of 
3 years (Randall et al., 1974), the use of the articulation test was discontinued. The statistically not significant differences In expressive language structure in this study show that severe articulation defects are not more common among the children malnourished in utero.

The higher level of performance on the verbal comprehension scale in comparison with the standardization sample of Reynell has been described before (Randall et al." 1974; stevenson et a1., 1976) and did not influence the identification of language delay.

Due to the absence of agreed criteria for language delay at different ages, the prevalence of the problem is not well known. In pediatric practice the most widely used criterion is referral to a speech therapist (Bax et al., 1980; Fiedlex et al., 1971; Schwartz et al., 1975) which leads to widely varying prevalence figures. Mackelth and Rutter (1972) report that at school entrance 18 of the chilldren show a marked language handicap whereas another 4 to 58 present the sequelae of earlier language difficulties. At the age of 3 years the prevalence rate of delayed language development varles from 2.58 (Randall et al., 1974) to 6.88 (Stevenson et a1., 1976) and 8.58 (Silva, 1980). The high rate of (eapecially expressive) language delay among the I.U.M. group in this study (32\%) is therefore remarkable.

In a tudy of the behavtour of 3-year-old children Richman and Graham (1971) experienced that language delay was a common feature in children considered to have behaviour problems, neurological dysfunction or retardation. The same phenomenon emerges in this study. It indicates that language delay can be considered as one of many possible expressions of brain dysfunction as a result of nutritional restriction during the brain growth spurt.

Fitzhardinge and steven (1972), studying term born S.G.A. infants (defined as having a birthweight below the $3 r d$ percentile 
for gestational age at 3 to 4 years of age, reported that 258 presented signs of minimal brain dysfunction and that 29 had speech problems and were referred to a speech therapist. In their material articulation defects were few" both receptive and expressive abilities were poor and many children had a poor vocabulary. Though we assessed a subgroup of S.G.A. Infants (1.e. those S.G.A. Infants showing clear-cut signs of intrauterine malnutrition) systematically using the R.D.L.S." our results compare well with those of Fitzhardinge and steven (1972). As the resulta of our study are in entire agreement with the data of Fitzhardinge and steven (1972) despite the different definitions of 'intrauterine malnutrition", it seems justified to suppose that there 1 a a relation between intrauterine malnutrition and delayed language development. As language delay is often seen in I.U.M. infants with significant behaviour problems (like concentration disorders and hyperactivity) these infants may benefit greatly by speech therapy in comblnation with behaviour therapy.

\section{References}

1. Babson, S.G., Kangas, J.: Preschool intelligence of undersized term infants. Am. J. Dis. Child. 117: 553-556 (1969).

2. Bax, M., Hart, H. and Jenkins, S.: Assessment of peech and language development in the young child. Pediatrics 66 $350-354(1980)$.

3. Dobbing, J., Sands, J.: Comparative aspect of the brain growth spurt. Early Hum. Dev. 3: 79-83 (1979).

4. Dubowitz, L.M.S., Dubowitz, V., Goldberg, C." Clinical assessment of gestational age in the newborn infant. J. Pediatr. $77 * 1-10(1970)$.

5. Fiedler, M.F., Lenneberg, E.H., Rolfe, U.T., Drorbaugh, J.E.: A speech screening procedure with three-year-old children. Pediatrics 48: 268-276 (1971). 
6. Pitzhardinge, P.M., Steven, E.M.: The small-for-date infant. II Veurological and intellectual sequelae. Pediatrics 50 : $50-57(1972)$.

7. Gruenwald, P.: Pathology of the deprived fetus and its supply line. In: Elliott, K., Knight, J. eds.: Size at birth. Ciba Fan. Symp. 27 (new geries). Amsterdam: Elsevier, 3-26 (1974).

B. Kloosterman, G.J.: On Intrauterine growth, the significance of prenatal care. Int. J. Gynaec. Obstet. 8: 895-912 (1970).

9. Mackelth, R.C., Rutter, M.: A note on the prevalence of language disorders in young children. In: Rutter, M. "Martin, J.M.A., eds. The child with delayed speech. Clinics In Developmental Medicine no. 43. Spastics International Medical Publications. London: Heinemann, 48-51 (1972).

10. Miller, H.C. and Hassanein, K.: Diagnosis of impaired fetal growth in newborn infants. Pediatrics 48: 511-522 (1971).

11. Neligan, G.A., Kolvin, I., Scott, D.Mcl., Garslde, R.F.: Born too soon or born too small. Clinics in Developmental Medicine no. 61. Spastica International Medical Publications. London: Heinemann, 1976 .

12. Peddemors-Boon, M., Van der Meulen, S., De Vries, A.K.: Utrechts articulatie onderzoek voor kinderen van 3 tot 6 faar. Amsterdam: Swets and Zeltlinger, 1977.

13. Randa11, D., Reyne11, J., Curwen, M.: A stuay of language development in a ample of 3 year old children. Br. J. Disord. of Commun. 9: 3-16 (1974).

14. Reymel1, J.: Reynell Developmental Language scales (Experimental edition). Windsor: N.F.E.R. Publishing Co., 1969 a.

15. Reynel1, J.: A developmental approach to language disorders. Br. J. Dilsord. of Commun. 4: 33-40 (1969 b).

16. Richman, N., Graham, P.J." A behavioural screening questionnaire for use with three-year-old children. Preliminary findings. J. Child. Psychol. Psychiatry 12: 5-33 (1971). 
17. Roord, J.J., Ramakers, L.H.J.: Quantification of intrauterine malnutrition. Biol. Neonate 33: 273-277 (1978 a).

18. Roord, J.J., Ramaekers, L.H.J., Van Engelshoven, J.M.A.: Intrauterine malnutrition and skeletal retardation. Biol. Neonate $34: 167-169(1978$ b) .

19. Rutter, M., Bax, M.: Normal development of speech and language. In: Rutter, M., Maring, J.M.A., eds. The chlld with delayed speech. Clinics in Developmental Medidne no. 43 . Spastics International Medical Publications. London: Heinemann, 1-12 (1972).

20. Schwartz, A.H., Murphy, M.W.: Cues for screening language disorders in preschool children. Pediatrics 55: 717-722 $(1975)$.

21. Silva, P.A.: The prevalence, stability, and significance of developmental language delay in preschool children. Develop. Med. Child Neurol. 22:768-777 (1980).

22. Stevenson, J., Richman, N.: The prevalence of language delay in a population of chree-year-old children and its association with general retardation. Develop. Med. Child Neurol. $18: 431-441(1976)$.

23. Thomas, Y.M., Bedi, K.S., Davies, C.A., Dobbing, J.: A stereological analysis of the neuronal and aynaptic content of the frontal and cerebellar cortex of weanling rats undernourlshed from birth. Early Hum. Dev. 3: 109-126 (1979).

24. Walther, F.J., Ramaekers, L.H.J.: Developmental aspects of subacute fetal distress: Behaviour problems and neurologlcal. dysfunction. Early Hum. Dev. 6: 1-10 (1982).

25. Winick, M.: Malnutrition and brain development. I. Pediatr. $74: 667-679(1969)$. 
Many people have been involved in realizing this thesis. I an grateful to all of them for their Invaluable help. In particular I am greatly indebted to Professor Dr. L.H.J. Ramaekers, who superviged this work and created the facilities to work on this subject. Furthermore I would $\mathbb{l}$ ike to express my deep appreciation towards all parents and their children who participated in the atudies that form the basis of this thesis.

I thank the nursing staff in the neontal unit for their help with the collection of the urine samples for the hydroxyproline study. The actual measurements were performed in the laboratory of clinical chemistry (Head: Dr. C. Mink) of the st. Annadal Hospltal. To complete the data 1132 clinical records had to be looked for by the medical administration (Head: M. Marres) and our almost indefatigable Miss Gerda verscheyden.

The initial data for the follow-up investigation were collected by Dr. J.J. Roord, Prof. Dr. L.H.J. Ramaekers and Dr. J.M.A. van Engelshoven. The lastmentioned performed the assessments of skeletal maturity at birth and at the age of 3 years. The stimulating help of Mrs. T. Kocken was indispensable for the behavioural screening of all children. Mrs. T. Buursen and Mrs. J. Th1jsen, third-year students of the Centre of speech Therapy In Hoensbroek, assessed the language development of all chilaren In the follow-up study with enthousiasm and patience. Their supervisor Mr. J. Lambert and Mr. Ch. Rutten gave expert assistance. Mrs. P. Roodenburg, speech therapist, was so kind to lend us har Reynell Language test.

MI. L. Strijbosch and Mr. A. Volovies of the DIV of the Univergity of Limburg gave me valuable advices and assisted me with the otistical analyses. Mr. S. Sweeris of the AV department has arawn all figures in the different publications. 
I acknowledge gratitude to Dr. P.A. Davies, Prof. Dr. C. Versluys and Prof. Dr. J. de Haan for their critical reading of the manuscript and their valuable commentary. Only alue to the good daily cooperation with the obstetric department (Head: Prof. Dr. J. de Haan), it was possible to perform the perinatal studies.

Special thanks must be reserved for Mrs. M. Rosbak, who skil1fully and intelligently typed and re-typed all manuscripts several times. She did a fantastic job. Miss Marijke van den Berg typed the final manuscript on the computerized type-setter.

Last but not least I like to thank my collegues for thelr willingness to take over my clinical duties during the periods in which the follow-up examinations were performed. 
Curriculum vitae

1948

$1960-1965$ : Middelbare schoolopleiding, Stevin Lyceum te 's-Gravenhave, elndexamen H.B.S.-B.

$1965-1972$ : Studie geneeskunde aan de Medische Faculteit van de Rijkaniversiteit te Leiden (1968-1970 etudent-assistentschap fysiologit)

$1972-1974$ : Arts-assiatentschap chirurgie (Opleider: Dr. K. Waldeck) en obotetrie (Dr. A.C. NieuwenhulzenKruseman), Rode Kruis Ziekenhulis, 's-Gravenhage Nationale Tropencursus voor artsen, Koninklijk Instituut voor de Tropen, Amsterdam

$1974-1977$ : Medical Officer in Charge, Kibara Mission Hospital, Kibara, Tanzania

1977

: Wetenschappelijk medewerker, Instituut 'Gezondheidgzorg in de ontwikkelingslanden" (Hoofd: Prof. Dr. V. van Amelsvoort), Katholleke Univerateit te Nijmegen.

$1977-1981$ * Opleiding tot kinderarts, st. Annadal ziekenhuis te Mastricht (Opleider: Prof. Dr. L.H.J. Ramaekersl.

1981 - heden : Als kinderarts verbonden aan de Capaciteitsgroep Kindergeneeskunde, st. Annadal ziekenhuis; Maastricht 